University of New Mexico

UNM Digital Repository

Summer 7-21-1971

\title{
A Comparative Study of How Parents from Different Social Classes Perceive School Health Services
}

John Joseph Pelizza

Follow this and additional works at: https://digitalrepository.unm.edu/educ_hess_etds

Part of the Health and Physical Education Commons 


\section{THE UNIVERSITY OF NEW MEXICO ALBUQUERQUE, NEW MEXICO 87106}

\section{Policy on Use of Theses and Dissertations}

Unpublished theses and dissertations accepted for master's and doctor's degrees and deposited in the University of New Mexico Library are open to the public for inspection and reference work. They are to be used only with due regard to the rights of the authors. The work of other authors should always be given full credit. Avoid quoting in amounts, over and beyond scholarly needs, such as might impair or destroy the property rights and financial benefits of another author.

To afford reasonable safeguards to authors, and consistent with the above principles, anyone quoting from theses and dissertations must observe the following conditions:

1. Direct quotations during the first two years after completion may be made only with the written permission of the author.

2. After a lapse of two years, theses and dissertations may be quoted without specific prior permission in works of original scholarship provided appropriate credit is given in the case of each quotation.

3. Quotations that are complete units in themselves (c.g., complete chapters or sections) in whatever form they may be reproduced and quotations of whatever length presented as primary material for their own sake (as in anthologies or books of readings) ALWAYS require consent of the authors.

4. The quoting author is responsible for determining "fair use" of material he uses.

This thesis/dissertation by John Joseph Pelizza_ has been used by the following persons whose signatures attest their acceptance of the above conditions. (A library which borrows this thesis/dissertation for use by its patrons is expected to secure the signature of each user.)

NAME AND ADDRESS

DATE

July $1971-1,000-$ GS 
This dissertation, directed and approved by the candidate's committee, has been accepted by the Graduate Committee of The University of New Mexico in partial fulfillment of the requiremints for the degree of

DOCTOR OF PHILOSOPHY

A COMPARATIVE STUDY OF HOW PARENTS FROM

Title DIFFERENT SOCIAL CLASSES PERCEIVE SCHOOL HEALTH SERVICES

John Joseph Pelizza

Candidate

Health, Physical Education and Recreation. Department
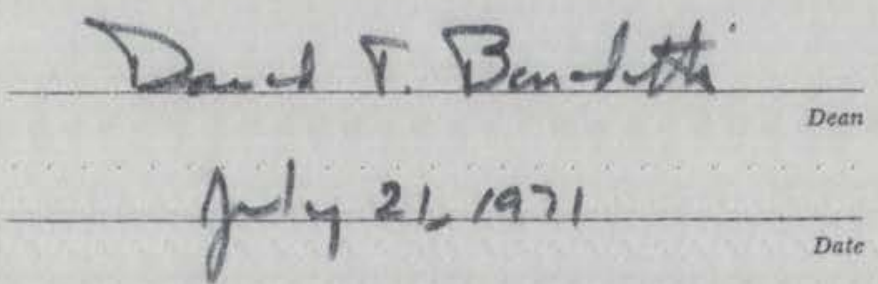

Committee
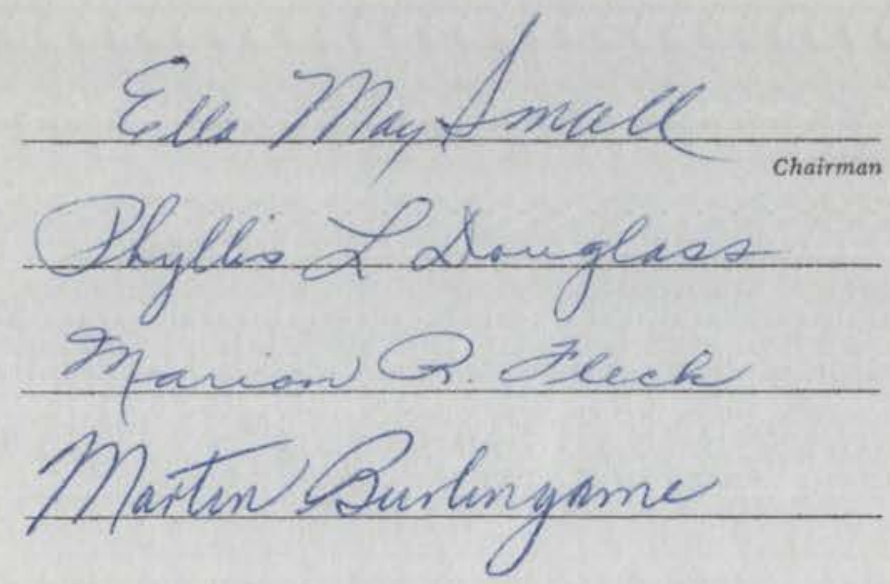
A COMPARATIVE STUDY OF HOW PARENTS FROM DIFFERENT SOCIAL CLASSES PERCEIVE SCHOOL HEALTH SERVICES

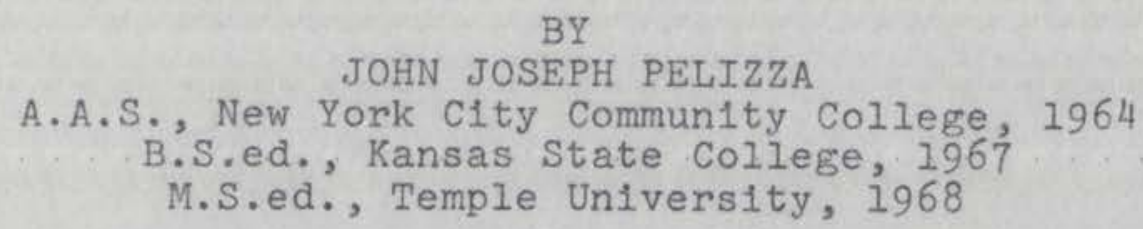

BY

JOHN JOSEPH PELIZZA

A.A.S., New York C1ty Commun1ty College, 1964

B.S.ed., Kansas State College, 1967

M.S.ed., Temple University, 1968

\section{DISSERTATION}

Submitted in Partial Fulfillment of the

Requirements for the Degree of

Doctor of Philosophy

in the Graduate School of

The University of New Mexico

Albuquerque, New Mexico

August, 1971 
The author wishes to express his sincere appreciation to the members of his Doctoral Committee for the opportunity to pursue the Doctor of Philosophy degree.

A special word of thanks and appreciation is extended to the dissertation Chairman, Dr. Ella May Small, whose markedly perceptive counseling, understanding, and encouragement made this work possible. Her constant support and help in the writing of this dissertation will always be appreciated. Sincere appreciation is extended to Dr. Martin Burlingame, an excellent teacher and a man of deep understanding and empathy. His constant support, time, patience, and help in the design and statistical analysis of this study were invaluable. He will always be remembered by the author.

The author is also very grateful to Dr. Marion Fleck for her time and encouragement in the writing of this dissertation. Her assistance to the author in securing permission to conduct the study in the Albuquerque Public Schools was extremely helpful.

Appreclation is extended to Dr. Phyllis Douglass for her persistent encouragement during the writing of this dissertation.

The cooperation given by the participating personnel of the Albuquerque Public Schools made this study possible. 
The writer is especially indebted to the following: Mr. Thomas Lockewood, Mr. C. J. Conrad, Mr. Carlos Saavedra, Mr. David Melvin, Mr. Vito M. Miera, Jr., Mr. Virgil Morgan, Mr. Oran Caton, Mr. Ray Barela, Mr. Everett Miller, Mr. Trancita Romero, and Mrs. Ruth Baker.

The author is especially indebted to Vivian Barfield who willingly gave of her time to make valuable and imaginative suggestions for the improvement of this manuscript. Her encouragement and prodding during the writing made the author believe that this dissertation was not only possible but worthy.

Three friends, Dr. Bobby Dean Brayboy, Mrs. Betty Sasmor, and Dr. Peter Yuan Kai Wang, who gave the author moral support, constant encouragement and friendship during the writing of this dissertation will always be remembered and cherished.

Finally, words cannot sufficiently express the support, patience, understanding, and love the author recelved from his wonderful parents, Evelyn and Joseph, his sister Lorraine, and from Bonnie Miller. To them this dissertation is lovingly dedicated. 
A COMPARATIVE STUDY OF HOW PARENTS FROM

DIFFERENT SOCIAL CLASSES PERCEIVE

SCHOOL HEALTH SERVICES

BY

John Joseph Pelizza

\section{ABSTRACT OF DISSERTATION}

Submitted in Partial Fulfillment of the

Requirements for the Degree of

Doctor of Philosophy in the Graduate School of

The University of New Mexico

Albuquerque, New Mexico

$$
\text { August, } 1971
$$


This study was designed to determine attitudes of parents from three different social classes toward school health services. The social class status of parents was determined by the use of Duncan's Soclal Class Index. This Index, consisting of four hundred forty-six occupations, was divided into a decile scale against which each parent's occupation was checked for a corresponding decile number. If a parent's occupation was not on the Index the investigator subjectively decided on a rating using Duncan's Social Class Index as a guide.

Parents of children enrolled in nine elementary schools (Pajarito, Coronado, Duranes, Inez, Monte Vista, Carios Rey, Chelwood, Acoma, and Comanche) in the Albuquerque Public School system composed the population for this study. The data from 2,533 questionnalres returned by these parents, were analyzed by three statistical tools. Frequency distributions and percentages were used to organize parent responses from the questionnaires; cross tabulation located parents in ten social class deciles; and, chi square was used to determine what differences, if any, existed among the responses of parents from the three social classes.

Two null hypotheses were tested in this study. Hypothesis I: There are no significant differences in attitudes of parents from differert social classes toward school health services. 
Hypothes1s II: There are no significant differences in the kinds of school health services wanted by parents from different social classes.

Hypothesis I was rejected and Hypothesis II was not rejected.

One major question to be answered as a result of the study was: What specific health services do parents from different social classes want the school to provide for their children? Comments made by parents at the end of the questionnaire provided the data related to this question. These data showed that while there are no significant differences in the kinds of school health services wanted by parents from different social classes, there was variation by social class in the intensity of these wants. 
. TABLE OF CONTENTS

CHAPTER

PAGE

I. INTRODUCTION . . . . . . . . . . . . . I

Statement of the Problem......... 4

Hypotheses ............. 5

Delimitations. . . . . . . . . . 6

Organization of the Remainder of the Study . . 6

II. REVIEW OF RELATED RESEARCH AND LITERATURE. . . . 8

School Health and Nursing Services... . . 8

Responsibility of School Health Services.. 9

The School Nurse and Nursing Services. . . . 13

Evaluation of School Health Services . . . 17

Problems Confronting School Health

Services.......... 20 20

Summary. . . . . . . . . . . 2 23

Studies of Social Class. . . . . . . 24

Characteristics and Definitions. . . . . 24

Lower Class. . . . . . . . 28

Middle Class . . . . . . . . . 28

Upper Class. . . . . . . . . 28

Measurement of Social Class. . . . . . . 29

The Questionnaire as a Research Tool . . . . 31

Advantages and Disadvantages of the

Questionnaire. . . . . . . . . 32 
CHAPTER

PAGE

Constructing the Questionnaire...... 34

Criteria for Evaluating a Questionnaire. . . 36

Summary. . . . . . . . . . . 37

II. METHODOLOGY. . . . . . . . . . . . . . 39

Preliminary Planning for the Study . . . . 39

Sampling Procedures. . . . . . . . . 40

Procedures for Collection of Data. . . . . 40

Selection of a Soclal Class Index. . . . . 41

Construction of the Questionnaire. . . . . 41

Format of the Questionnaire. . . . . . 4 42

Pretesting the Questionnaire... . . . . 43

Distribution of the Questionnaire. . . . . 44

Analysis of Data . . . . . . . . . . 45

Statist1cal Procedures . . . . . . . . 45

Summary. . . . . . . . . . . . 45

IV. PRESENTATION AND ANALYSIS OF DATA. . . . . . 47

Treatment of the Data. . . . . . . . . 47

Frequency Distribution . . . . . . . 48

The Null Hypotheses. . . . . . . . . 54

Hypothesis I. .. . . . . . . . 54

Hypothesis II. . . . . . . . . 63

Major Question ........... 63

Health Services Wanted by All Social

Classes. . . . . . . . . . 64 
CHAPTER

PAGE

Health Services Wanted Only by the Lower Class. . . . . . . . . 64 Health Services Wanted Only by the Middle Class . . . . . . . . 64 Health Services Wanted Only by the Upper Class. . . . . . . . . . 65 Summary. .............. 66

V. FINDINGS AND RECOMMENDATIONS . . . . . . . 67 Findings - School Health Services. . . . . . 67 Findings - The Influence of Social Class on School Health Services. . . . . . . . 71 Recommendations.................... 75

Recommendations for Further Studies. . . . . 76 BIBLIOGRAPHY . . . . . . . . . . . . . . 78 APPENDIX A . . . . . . . . . . . . . . . 84 APPENDIX B . . . . . . . . . . . . . . . . 91 APPENDIX C . . . . . . . . . . . . . . 108 APPENDIX D . . . . . . . . . . . . . . 121 APPENDIX E . . . . . .............. . 131 CURRICULUM VITAE . . . . . . . . . . . . . . . 142 
TABLE

PAGE

1. The Number and Percentage of Questionnaires Returned by Each Social Class . . . . . . 109

2. Frequency Distribution of the Total Number and Percentage of Parent Responses. . . . . 110

3. Percentages of Yes-No Responses for Each Questionnaire Item . . . . . . . . 48

4. Parent Responses to Questionnaire . . . . 112

5. Summary of the Number and Percentage of

Parent Responses Grouped by Social Class and School. . . . . . . . . . . 53

6. Significance of Differences from a Comparison of Responses from Different Social Classes. . 56

7. Clusters of Scores Indicating the Degrees of Support for School Health Services by Parents of Three Social Classes . . . . . . 59

8. A List of Health Service Items Which Illustrate The Varying Degree of Approval Between Upper and Lower Class Parents . . . . . .

9. A List of Health Service Items Which Illustrate the Varying Degree of Disapproval Between Middle and Lower Class Parents. . . . . . . 
- LIST OF FIGURES

FIGURE

PAGE

1. Percentages of Yes-No Responses for Five

Items That Were Not Supported by Parents. . . . 51 
CHAPTER I

\section{INTRODUCTION}

Today's school health program is an outgrowth of public concern for meeting the health needs of an ever changing society. Initially, school health services emphasized the control of contagious disease by providing frequent medical inspections of pupils. In $1894 \mathrm{Dr}$. Samuel Durgin, Health Commissioner of the city of Boston, introduced the first regular school program of medical inspections in the United States. Similar programs were instituted in Chicago in 1895, New York in 1897, Philadelphia in 1898, and in Massachusetts in $1906 .^{1}$

As medical inspections increased in quantity and improved in quality, educators accepted the 1dea that the public schools should assume a significant part of the responsibility for protecting, maintaining, and improving the health status of school children. The rapid urbanization of American life made it essential for public schools to assume many functions that had been previously left to the family in an agrarian society. Justification for this extension of health services was based on the premise that social changes made it impossible

${ }^{1}$ C. L. Anderson, School Health Practice (St. Louis:

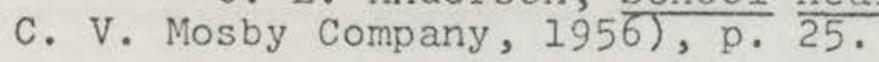


to leave the entire responsibility for the health of children on the parents. Early educators such as Mann and Allcott advocated the need for removing physical impediments if children were to be made responsive to the educational process. During the years 1907 to 1915 impetus for more school health services was provided by the White House Conference on Child Health which stimulated interest in dental inspections, general physical examinations, and remedial measures for defective vision and hearing. ${ }^{2}$

The need for more school health services grew as the school population increased. The scope of the school health service expanded until presently the program may include: (1) appraising the health status of puplis and school personnel, (2) counseling pupils and parents concerning appraisal findings, (3) encouraging, and when possible, providing the correction for remediable defects, (4) helping to plan and to care for the education of handicapped children, (5) helping to prevent and control disease, and (6) providing necessary first aid for the sick or infured. ${ }^{3}$

The role of nursing services was to provide many of

${ }^{2}$ Merle Curti, The Soclal Ideas of American Educators (Paterson, New Jersey: Pagent Books, Inc., 1959), p. 247.

3 "Committee on Terminology in School Health Education," Journal of the American $\frac{\text { Association }}{\text { Education, }}$ and $\frac{\text { for }}{\text { Recreation, }}$, No. Nealth, $\left.\frac{\text { Physical }}{\text { (September, }}, 1951\right)$, p. 14. 
the health services that compose the school health service program required by school children. It must be recognized that school health services and school nursing services are not synonymous. However, school nurses are primarily responsible for the delivery of school health services.

Two important elements in the evolution of school health services were professional school and medical personnel. These two groups were primarily responsible for the kinds of school health services provided by the schools. It was assumed by these professional groups that as professionals they knew what was best for school children. The writer found no evidence that parents have ever been much involved in planning for school health services or that social class differences were considered when determining what school health services should be provided by the public schools.

According to Kahl, a tendency exists for persons within each social class to become similar to each other and distinct from other social class strata. In other words, the various stratification variables tend to converge and form a pattern. It is this pattern that creates social classes. 4 Therefore, an intriguing assumption is that parents from different social classes may wish to have a much greater role in the determining

${ }^{4} \mathrm{Joseph}$ Kahl, The American Class Structure (New York: Rinehart and Company, Inc., 1957), pp. 11-13. 
of what health services are to be provided by the nurse in public schools. This led the present investigator to propose two questions: ( 1 ) What school health services do parents from different social classes want for their children? and (2) Do parents from different social classes want varying kinds of school health services for their children? Answers to these questions are vital if school health service programs are to meet the needs of school children.

\section{STATEMENT OF THE PROBLEM}

The purposes of this study were: (1) to determine the attitudes held by parents of different social class groups toward the health services provided by the Albuquerque Public Schools, and (2) to find out what differences existed among the attitudes held by parents in three social class groups concerning these health services.

That social class influences personality is a basic postulate for social scientists. ${ }^{5}$ Extrapolation from this postulate infers that individuals from different social classes have different behavior patterns and attitudes, and that these differences in behavior and attitudes cause different social classes to look at the world differently. Thus, members of

${ }^{5}$ Darwin Dennison, "Health Behavioral Differences Between Low and Middle Social Class Students," Journal of School Health, Vol. XXXIV, No. 10, (December, 1969), p p. 731-735. 
different classes could be looking at the same object but what each sees will vary because of what he has been taught to see within his respective social class.

A major theory of the present investigator was that: (1) parents from the same social class want similar types of health services, and (2) parents from different social classes want different kinds of health services for their children.

The functions of today's school health service program have expanded to include a multitude of services. The emphasis In school health services has evolved from that of preventing contagious disease to a highly sophisticated program designed to help meet the needs of the child's total development. Current objectives include the protection, maintenance and improvement of the physical, mental, emotional, and social well-being of the child.

\section{Hypotheses}

The hypotheses in this study focused on the relationship between attitudes of parents from different social classes and how parents perceived health services. Specifically, the following null nypotheses were tested in this study:

Hypothesis I. There are no significant differences in attitudes of parents from different social classes toward school health services.

Hypothesis II. There are no significant differences 
In the kinds of school health services wanted by parents from different social classes.

While most earlier studies of health services dealt with the specific functions of school health personnel, this investigation was concerned with the kinds of health services parents wanted for their children and the effect of social class upon these parental decisions. Hence a major question of the present study was: What specific health services do parents from different social classes want the school to provide for their children?

\section{DELIMITATIONS}

The study was delimited to the data gathered by a questionnaire. The subjects particlpating in the survey were parents of children in nine elementary schools in the Albuquerque Public School System selected to represent different social class populations. The writer made no attempt to evaluate school health services. The purpose of the investigation was to determine if, in the perceptions of the parents, schools were providing the kinds of health services that parents from different soclal classes wanted for their children.

ORGANIZATION OF THE REMAINDER OF THE STUDY

Chapter II provides a review of the research and literature related to school health and nursing services, social 
class, and the questionnalre as a research tool. The research design and procedures for the study follow in Chapter III. The results of the investigation are reported in Chapter IV. Chapter $\mathrm{V}$ contains findings and recommendations of the study. 


\section{- CHAPTER II \\ REVIEW OF RELATED RESEARCH AND LITERATURE}

The research and literature reviewed for the present study included books, theses, dissertations, and studies reported in professional journals and pamphlets. The following section is divided into three major sections: (1) studies related to school health and nursing services, (2) studies dealing with social classes, and (3) the research tools used.

\section{SCHOOL HEALTH AND NURSING SERVICES}

The origin of school health services dates back to the late elghteen hundreds when regular programs of medical inspections were instituted in many public schools to help control contaglous diseases. Through the years school health services expanded to include a multitude of services other than the protection from diseases. To meet the added responsibilities a variety of medical personnel such as physicians, dentists, and nurses were employed by the public schools. With the coordination of medical and school personnel, school health services became an integral part of the total school program.

At the present time the comprehensive scope of school health services is illustrated in the following definition:

The procedures used by the physicians, dentists, nurses, teachers, etc., designed to appraise, protect, and promote optimum health 
of students and school personnel. (Activities frequently included in school health services are those used to: (1) appraise the health status of students and school personnel; (2) counsel students, teachers, parents and others for the purpose of helping school-age children get treatment or for arranging education programs in keeping with their abilities; (3) help prevent or control the spread of disease; (4) provide emergency care for infury or sudden sickness.) ${ }^{1}$

This definition exemplifies the broad spectrum of health service responsibilities delegated to the schools.

\section{Responsibility of School Health Services}

The question of who should be responsible for school health services was a viable one. Frary stressed that schools along with other agents of society had a responsibility to provide adequate health services for school children. For this to be accomplished the focus of school health services may have to change. ${ }^{2}$ Frary suggested two concepts for improvIng school health services: (1) school health services should take a hollstic approach to the student, and (2) services should be person centered rather than program centered. ${ }^{3}$ According to Frary another important factor to consider

${ }^{1}$ A Joint Committee on Terminology, "Health Education Terminology," Journal of School Health, Vol. XXXIII, No. 3, (March, 1963), p. 121.

${ }^{2}$ Ruth A. Frary, "School Health Services: Kindergarten Through College," Journal of School Health, Vol. XXXVIII, No. 4, (April, 1968), pp. 207-212.

${ }^{3}$ Ibid. 
was that school health services must be seen as a continuum which places the responsibility for adequate health of young school children primarily with parents. The school health service program should aid parents in this responsibility but not replace them. ${ }^{4}$ Finally, Frary stated that all school health service programs must be viewed as one part of the total community health picture. The duplication, fragmentation, and overlapping of health services in many communities made it mandatory for each institution providing health services to look carefully at its role and function. ${ }^{5}$

The need for school health services can be based upon four factors according to Wallace. Briefly, these factors are: (1) Since most children attend school for a substantial period of time, an effective school health service program can be an influential factor in the health of our entire population. (2) School children are relatively easy to reach because school attendance laws make it manditory for them to attend school; therefore, their health status can be readily appraised. (3) Each family and comrnunity are responsible for helping children to grow and develop into reasonably healthy, happy, and productive adults. And, (4) preventable and remediable causes of morbidity and mortality among school age

${ }^{4}$ Ibid 
children can be reduced by an effective school health service program. 6

Means summarized the recommendations made for school health services at the 1950 White House Conference on Children and Youth as follows: (1) to secure effective school health services through the cooperative action of all professions and agencies concerning the health status of school chlldren, and (2) to coordinate health services in the schools with allied health professions in order to achleve optimal physical, mental, and social well being of school children. 7

In a recent monograph by the American Association of Health, Physical Education, and Recreation, it was noted that recent developments, made possible through federal legislation, have resulted in schools making more demands on school nurses. Many school districts increased the scope of their nursing service, while others added school nursing services where they were formerly nonexistent. 8

6 Helen M. Wallace, "School Health Services," Journal of School Health, Vol. XXIX, No. 8, (October, 1959), pp. 283-295.

7 Richard K. Means, "Contributions of the White House Conference on Children and Youth to School Health Education," Journal of School Health, Vol. XxX, No. 9, (November, 1960), pp. $323-\overline{33} 3$.

${ }^{8}$ National Council for School Nurses of the School Health Division of the American Association for Health, Physical Education, and Recreation, "Solutions to Critical Health Needs," School Nursing Monograph, No. 1, (1969), pp. 1-38. 
Kreidberg and Reed, after increasing health services for school children who lived in a typical lower class innercity community with a mixture of Negro, Puerto Rican, and Chinese groups, found that there was little or no perceptible increase in the utilization of these health services by the lower class families in the communities involved. This fact may be attributed to the different health perceptions of parents and the "vast cultural differences which exist between the group wishing to give the health services and the group for whom the health services are intended." 9

Wysong and Elchhorn stated that an individual's position in the social class structure of society determines both his health status and the manner in which he perceives his health status. 10

School health services have a responsibility to provide for the vast differences among social classes. Concern for the differences among social classes was noted by the National Committee on School Health Policies of the National Education Association and the American Medical Association in the

9 Marshall Kreidberg and Homer B. C. Reed, Jr., "An Experimental Problem for the Delivery of Health Care Services to Public School Chilaren," Journal of School Health, Vol. XXXIX, No. 4, (April, 1969), pp. $231-235$.

10 Jere A. Wysong and Robert L. Eichhorn, "Reaching the Tuberculosis Poor," Poverty in the Affluent Society, (New York: Harper and Row, 1966), pp. 223-243. 
following policy statement:

The ideal health service program is based on accepted standards and is adapted to a particular community. It is influenced by local customs, the variety of professional personnel and other resources available, and the local awareness of the health needs of children and youth. 11

The School Nurse and Nursing Services

According to the American Nurses' Association, school nursing is defined as:

*. a highly specialized service contributing to the process of education. That it is a socially commendable, economically practical and scientifically sound service can be well demonstrated. It must be diligently pursued through health and educational avenues to the end that positive health among all the citizenry of this country w1ll be a reallty.

Although the school is the institution through which some health services are rendered, the school nurse is primarily responsible for delivering most school health services. According to a study by Nellson the school nurse was responsible for health records, keeping them in order and available for use by other school personnel. Although the school nurse prepared the health records of students, other members of the school professional staff such as the administrator, guidance

${ }^{11}$ National Committee on School Health Policies of the National Education Association and the American Medical Association, "Suggested School Health Policies," (1966), p. 12.

12 American Nurses' Association, "School Nursing," (New York: American Nursing Association, 1966), 0. 1 . 
counselor, teacher and medical advisor, had access to the pupil's health records. 13

The Joint Committee on Terminology defined a school nurse as, "An individual with preparation in both public health nursing and education who works cooperatively with teachers, parents, and students to help achieve the purpose of the school health program." 14

A more elaborate and refined explanation of a definition of the school nurse was provided by Byrd who stated:

By virtue of the administrative leadership under which she serves, the school nurse may be an allen among teachers, a school refugee from the hospital ward, or a valuable member of the educational team. In the last role she may serve pupils and school employees alike in a mutual growth toward better understanding of the many relationships between health and learning. The leader who uses the school nurse in the performance of duties that are not in keeping with her professional training is overlooking a potential force around which the entire school health program may be orlented, for the nurse can be a resource for teachers, an assistant to the physician, an educator to the parents, and overseer for the school environment and a help to the administrator on all matters pertaining to health. 15

The fundamental concept of the function of a school

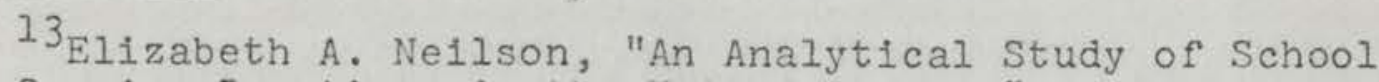
Health Service Practices in the United States," Journal of School Health, Vol. XXX, No. 9, (November, 1960), pp. 353-359. 14 A Joint Committee on Terminology, op. cit., p. 121. ${ }^{15}$ Oliver E. Byrd, School Health Administration (Philadelphia: W. B. Saunders Company, 1964), p. 168. 
nurse is to render health services need by school children. Fricke, in 1959, submitted to the American School Health Association the following recommendations to serve as guidelines for schools in determining the functions of the school nurse. The school nurse:

1. Gives leadership and guidance in the development of a total school health program.

2. Participates in the formulation of policies, standards, and objectives of a school health program.

3. Serves as a consultant to the administrator, parents, children and teachers in regard to the health needs of children.

4. Assists in planning the budget for health services.

5. Serves as a member of the school council.

6. Acquaints the administrator and other school personnel with health problems and resources in the school, home, and community.

7. Participates in the coordination of the school. program with the total health program of the school and community.

8. Assists in planning and conducting in-service health education for school personnel.

9. Participates in curriculum planning and evaluation.

10. Uses health services as a means of direct and indirect health education.

11. Is an active participating member in faculty and parents' meetings.

12. Is an active participating member in school building meetings.

${ }^{16}$ Irma B. Fricke, "Recommended Policies and Practices 
In addition to the above competencies and abilities that a school nurse should possess, the interdisciplinary committee for school nurses stated that an understanding of social class structure was also desirable. ${ }^{17}$

The Committee on Functions, Standards, and Qualifications for Practice, the School Nurses Branch, and the American Nurses' Association Public Health Nurses Section, stated that:

The functions of the school nurse will be dependent on such factors as school policy, her own preparation and experience, pupll load, needs of particular pupils in the school, and
the availability of other community services. 18

A study by Bryan and Cook $^{19}$ dealt with the two-fold problem of developing more effective ways to cope with the problems of the culturally and educationally disadvantaged child, and developing more effective methods of utilizing the knowledge and skills of the school nurse. The most significant conclusion from the Bryan and Cook study was that the

for School Nursing," Journal of School Health, Vol. XXIV, No. 10, (December, 1959), p. 30.

17 Helen Goodale Florentine, "The Preparation and the Role of Nurses in School Health Programs," National League for Nursing (1962), pp. 9-11.

${ }^{18}$ American Nurses' Association, Public Health Nurses Section, and School Nurses Branch, "Functions and Qualifications for School Nurses," (July, 1960), pp. 1-3.

${ }^{19}$ Doris S. Bryan and Thelma S. Cook, "Redirection of School Nursing Services in Culturally Deprived Neighborhoods," Journal of School Health, Vol. XXXIV, No. 4, (April, 1969), pp. 247-248. 
nursing profession must identify goals of nursing services that can be realistically achieved in culturally diverse schools through intervention (going into the community and talking to parents) rather than emphasis on activities to be performed or procedures to be carried out which may be unrelated to the needs and problems of students and families.

\section{Evaluation of School Health Services}

The conscientious administrator of school health services looks for ways and means of making health services more effective. This entails continuous evaluation of all aspects of the school health service program including: (1) personnel, such as school nurses, doctors, dentists, and paramedical help, (2) resources of community health agencles, and (3) health needs of students.

How effectively do schools utilize community resources in providing school health services? Tower and Fay stated that in light of many experiences with a number of school districts there tends to be a lack of utilization of community resources for school health services. 20

Cromwell, in 1964, called for an evaluation of all current school health service procedures. ${ }^{21}$. There are

${ }^{20}$ Billie Tower and Patricia Fay, "Can Contracted School. Health Services Work?," Journal of School Health, Vol. XXXVIII, No. 6, (June, 1968), pp. $\frac{339-341}{\text {. }}$ ${ }^{21}$ Gertrude E. Cromwell, "The Future of School Nursing," 
Indications that a new culture with new demands is developing. School nurses need to know about attitudes, the use of medical and health resources, and other relative factors in order to develop a health service program that accomodates a changing society. 22

Wallace cited the need to analyze the health services provided by the schools to determine which services were appropriate for school children and which were inappropriate. Such a procedure is urgent because population growth w1ll make even greater demands on the health service provided by the schools. 23

Social class is an important reference point in evaluating health services. With reference to social class, Warner wrote,

Our most democratic institutions, including our schools, churches, business organizations, government, and even our family life, are molded by its [social class] all-pervading and exceedingly

Burney reported that the lower class individual wanted

Journal of School Health, Vol. XXXIV, No. 1, (January, 1964), ${ }^{22}$ Ibid.

23 Helen M. Wallace, "Evaluation of School Health Services," Journal of School Health, Vol. XXXIII, No. 4, (April, 1963), p. 174.

24 Lloyd W. Warner and others, Social Class in America (New York: Harper and Row, 1960), p. 7. 
to have a part in the decision making process related to the kinds of health services received. Cognizance of this factor makes it imperative that school health service programs adapt to the ever changing society. 25

According to Goerke and Stebbins, higher rates of mortality and morbidity among children of lower class families was due to social class factors rather than racial differences. 26

An important part of all school health service programs should be periodic evaluation. A report by the Committee on School Health Service Statistics noted that five major benefits can be derived from adequate school health service statistics. They were as follows:

1. To determine the health and medical care needs of the population served.

2. To show how adequately these needs are being met.

3. To provide some measure of the amount of service being rendered and the amount of time physicians, dentists, nurses, teachers, and other health personnel devote to the school health service program.

4. To provide data for health education.

5. To indicate at least roughly the amount of health service time devoted to such health education activities as teacher-nurse conferences and physician,

${ }^{25}$ Leroy E. Burney, "New Missions in Health Services: To Act or to React?" Journal of School Health, Vol. XL, No. I, (January, 1970), p. 4 .

${ }^{26}$ Lenor S. Goerke and Ernest L. Stebbins, Mustard's

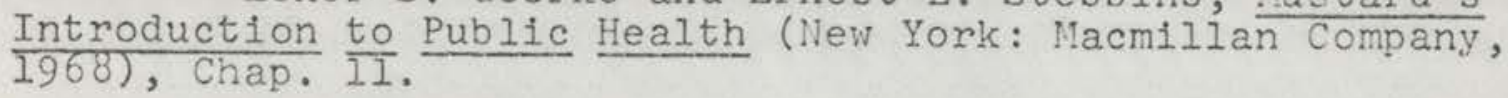


dentist, nurse, and health educator participation in faculty and PTA meetings.?

One committee suggested that in many instances certain school health services and nursing duties may have become obsolete. A plausible solution to this problem would be to establish priorities when setting up health service programs and incorporating some means of evaluating and redirecting health services at regular intervals. ${ }^{28}$

\section{Problems Confronting School Health Services}

Campbell cited two important problems confronting school health services. 29 The flrst described the general lack of information about the objectives, scope, and limitations of school health services. The second problem dealt with school administrators and their lack of dynamic leadership in the area of school health services. Too often administrators falled to encourage school health services and thus decreased the effectiveness of the program. Campbell also noted that when the average parent was asked to define school health services, a common answer was: "There are some kinds of

${ }^{27}$ Committee on School Health Service Statistics-School Health Section, "School Health Service Statistics," American Journal of Public Health, Vol. 46, (January-June, 1956), p. 637 . 28 Monograph No. 1 , op. cit.

${ }^{29}$ Elizabeth P. Campbell, "School Health ServicesProblems-Solutions-Ideas as Viewed by The Board of Education," Journal of School Health, Vol. XXVII, No. 3, (March, 1957), 
health examinations, evaluations I believe they now call them, but I don't know just when they are given or by whom. I think parents help with them too." 30 This lack of understanding by parents concerning school health services must be recognized and dealt with.

Jenne, in a recent study, 31 focused upon the frequency with which teachers observed health problems among their pupils. The data revealed two significant findings. First, teachers of pupils from lower social classes reported higher rates of observed health problems among their pupils than did teachers of middle and upper social class pupils. Second, school nurses reported spending more time per week in the lower social class schools than in the middle and upper social class schools. An important conclusion of the study was that the more time school nurses spend in a school, the greater the possibility that the teachers in that school will observe health problems among their pupils.

Paige claimed that the delivery of school health services to the poor were inadequate. ${ }^{32}$ A critical factor with

\section{${ }^{30}$ Ib1d.}

${ }^{31}$ Frank H. Jenne, "Variations in Nursing Service Characteristics and Teachers' Health Observation Practices,"

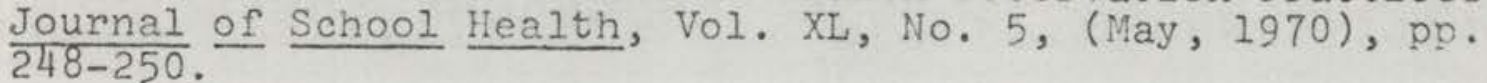

32 Joseph C. Paige, "Health Programs for the Disadvantaged: Implications for School Health," Journal of School Health, Vol. XL, No. 3, (March, 1970), pp. 123-126. 
respect to adequate school health service programs was what appeared to be a general lack of understanding and commitment on the part of school teachers, administrators, school boards, and too often, the parents of school children. What was needed, Paige argued, was a new kind of school health service delivery system to meet the needs of school children in different social classes.

Some health service programs for the poor are criticized by Shannon because of the impersonal and dehumanizing attitudes of the providers. To reduce such criticism the relationship between the provider and consumer should be based on a common understanding of health attitudes. 33

The reference group of an individual helps to determine attitudes. Straus reported, "Man is a social creature and many. of his needs are met through his interaction with other human beings. High in the hierarchy of sociological determinants of behavior one would list the behavior of his reference groups, . . those belonglng to the same soclal stratification group. $" 34$

According to Steinman, individual and family beliefs,

${ }^{33}$ Iris R. Shannon, "Nursing Service at the Mile Square Health Center of Presbyterian-St. Luke's Hospital," American Journal of Public Health, Vol. 60, No. 9, (September, 1970), p. 1731 .

${ }^{34}$ R. Straus, "Sociological Determinants of Health Beliefs and Behavior," American Journal of Public Health, Vol.

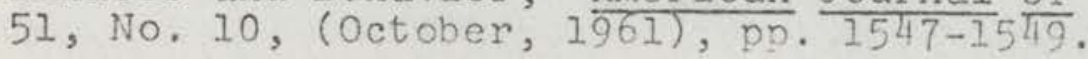


attitudes, and values, as well as one's social level, affects the state of health as perceived by the individual. Lack of understanding and communication in terms of what is wanted by the poor and what is provided by the medical professionals is another significant barrier that prevents adequate health services being provided to the rural poor. To progress, the provider must learn to understand the consumer's social, ethnic, and economic position. The interaction of the provider and the consumer must be studied if the health services provided are to be appropriate and useful. 35

\section{Summary}

The literature reviewed in this section dealt with: (1) the origin and responsibility of school health services, (2) the responsiblilties of the school nurse and nursing services, (3) the evaluation of the school health service program, and (4) problems confronting school health services. Studies by a number of authors suggest that social class influences the kinds of school health services provided by school nurses. This finding suggested that health services needed for school children in one social class strata may be different from other strata. Hence the literature supported the notion that social class may have an influence on school

${ }^{35}$ David Steinman, "Health in Rural. Poverty: Some Lessons in Theory and from Experience," American Journal of Public Health, Vol. 60, No. 9, (September, 1970), $\frac{10 u}{n .1823}$. 
health services.

\section{STUDIES OF SOCIAL CLASS}

Characteristics and Definitions

A persistent problem in the study of social class has been the lack of any well defined method for identifying social classes. Unfortunately, there still is no agreement among sociologists on what specific factors delineate a "social class." However, during the past two decades there have been numbers of theoretical developments that indicate more clearly some of the distinguishing factors of soclal class.

According to Weber there are two criteria to be considered in the study of social class. First, the dimensions of economic position, social status, and power must be kept analytically distinct. Second, the position of an individual in these separate dimensions may not always be identical; frequently it varies. 36

Hiller defined social class as "any comparatively permanent division in society which is differentiated by relatively persistent dissimilarities in rank and separated from other

36 Max Weber, "Class, Status, Party," Essays in $\frac{\text { Sociology }}{180-195 \text {. }}$ (New York: Oxford University Press, 1946), pp. 
strata by social distance." 37

Kahl added illustrations to the definition of social class :

A family shares many characteristics among 1ts members that greatly affects their relationships with outsiders; the same house, the same income, the same values. If a large group of families are approximately equal to each other and clearly differentiated from other families, we call them a social class. 38

This view was supported by Mayer who viewed social class as a "social hierarchy based primarily upon differences in monetary wealth and income." 39

Hodges referred to social class in terms of the way people live, eat, play, mate, dress, work, and think at contrasting and dissimilar levels. These levels of social class are the blended products of similar and analogous occupational orlentations, educational backgrounds, economic positions, and life experiences. 40

Hodges also implied that there was something more to social class than just aggregates of individuals who occupied

37 E. T. Hiller, Principals of Sociology (New York:

Harper and Brothers, ig 33$), \mathrm{pp} \cdot 36-37$.

${ }^{38} \mathrm{Kahl}$, op. cit., p. 12 .

${ }^{39}$ Kurt B. Mayer, Class and Society (New York: Random House, 1955), pp. 7-8.

${ }^{40}$ Harold M. Hodges, Social Stratification Class in America (Cambridge, Massachusetts: Schenkman Publishing Company, Inc., 1964), p. 13. 
similar points on prestige, economic and occupational scales. ${ }^{41}$ Berger gave credence to this theory when he stated, ". . We are beginning to catch a glimpse of the way in which society penetrates the insides of our consciousness." 42 Kahl, too, supported this when he wrote, ". . people who share a given style of life tend to have more personal contact or interaction with one another than with those who live differently." 43 In the Marxist milieu, "The economic system, broadly defined, was the source of class divisions and the force for continued stratification." 44 The veracity of this was questioned by Weber and Warner. Weber, like Marx, recognized the Importance of economic processes, but included the elements of class, status, and political party, as vital factors in the total scheme of social class. Warner felt the primary force that determined social class resulted from community judgments made about individuals. These evaluations were based upon the individual's status which included occupation, social participation, family background, and life style. ${ }^{45}$

${ }^{41}$ Ibid.

${ }^{42}$ Peter L. Berger, Invitation to Sociology: A Humanistic

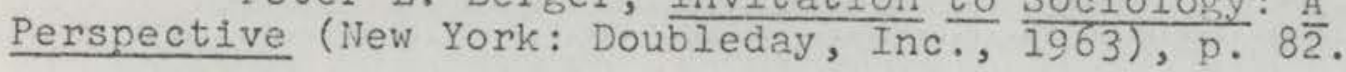

${ }^{43} \mathrm{Kahl}$, op. cit., p. 9.

44 Leonard Reissman, Class in American Society (New York: Free Press, 1959), p. 103 .

${ }^{45}$ Ibid., p. 104. 
In defining Marxism, Barber ". . . asserted that stratification, whether based on evaluation, income, or power, is determined by men's position in relation to production. It also claims that all three are in nearly perfect correlation one with the other." 46

A slightly different definition by Williams was that social class is ". . an aggregate of individuals who occupy a broadly similar position in the scale of prestige . . . "47 In the studies reviewed it was obvious that the overlapping concepts of social class preclude any precise definition.

From the literature reviewed the number of social classes in our soclety can range from two to six strata depending upon the particular stratification scale employed. However, the most commonly used were found to be: (1) the lower-class consisting of unskilled manual workers, (2) a midale-class of white-collar workers and professionals, and (3) an upper-class of power, prestige, and inherited wealth. A more descriptive explanation of low, middle, and upper social classes was provided by Roach, Gross, and Gurssin:

${ }^{46}$ Bemard Barber, Social Stratification - A Comparative Analysis of Structure and Process (New York: Harcourt, Brace, and Company, 1957), p. $\overline{53}$.

47 Robin M. Williams, Jr., American Society: A Sociological Interpretation (New York: A.lfred A. Knopr, I960), p. 98. 
Lower Class: Persons in the lower class live at or below. a subsistence level (the poverty line) throughout their lives. They exist in poverty as children and raise their own children under conditions of economic deprivation. Crowded, substandard housing; inadequate food and clothing; and lack of proper medical care are the significant facts of life. The behavior of lower-class persons 4 ts usually outside the malnstream of cultural control. 48

Middle Class: Middle class persons are distinguished from those above them by their more limited possessions of wealth and power and from those beneath them by their occupational pursuits. Middle class people have occupations requiring thinking rather than hand labor. Thus, they are concentrated primarily in professional, technical, administrative, sales and

Upper Class: Among these people the dominant group (those more securely established) has possessed wealth for several generations, and along with it, a distinctive life style. They are the primary carriers of upper class culture. (Persons with newly acquired 50

Such differences in soclal class position between low, middle, and upper class individuals suggested a relationship between social class and parents perceptions of school health services. The literature reviewed has shown that individuals from different soclal classes react differently to health services.

${ }^{48}$ Jack L. Roach, Llewellyn Gross, and Orville R. Gursslin, Social Stratification in the United States (Engle-

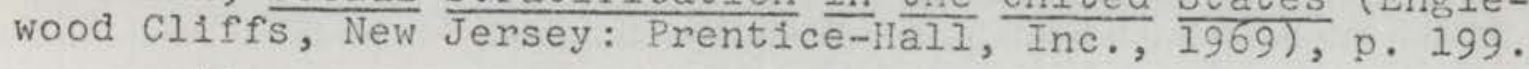

${ }^{49}$ Ibid., p. 167.

${ }^{50}$ Ibid., pp. 154-155. 
Measurement of Social Class

At the present time there are a number of indices to measure social class. The Index of Class Position (ICP) developed by Ellis and Lane used occupation and class identification as the major components for the identification of social class. The rationale for using these two components was based upon the factors that occupation has a high correlation with social status, and class identification provides a means for estimating the respondent's own definition of this status situation. 51

Kahl, Gordon, Warner, and Hollingshead each developed lists of variables to study social class. Although all lists were similar, each contained a sufficient degree of dissimilarity to warrant listing.

Kahl's Six Variables to Study Social Class: $:^{52}$
1. Prestige
2. Occupation
3. Possessions
4. Interaction
5. Class-consciousness
6. Value orientation

Gordon's Five Variables to Study Social Class : ${ }^{53}$
1. Income
2. Occupation
3. Status groups
4. Community power
5. Dwelling area or residence

${ }^{51}$ Ib1d., pp. 106-110.

52 Kahl, oㅗ. cit., p. 10.

53 Milton M. Gordon, A System of Social Class Analysis (Madison, New Jersey: Drew University, $\frac{\text { Soc1al }}{1951)} \frac{\text { Class }}{\text { p. } 13 .}$ 
Warner's Six Variables to Study Social Class: $:^{54}$

1. Occupation

2. Amount of income

4. Education

5. House type

3. Source of income 6. Dwelling area type

Warner also developed two other indices to study social class: Evaluated Participation (E.P.) and the Index of Status Characteristics (I.S.C.). 55 These two methods provided a means to measure an individual's position in a particular social class. They also allowed the investigator to validate the results obtained.

Hollingshead's Five Variables to Study Social Class: ${ }^{56}$

1. Place of residence, dwelling type, and furniture

2. Income and material possessions

3. Participation in community affairs

4. Family background

5. Reputation or prestige

According to Miller one of the best subjective assessments of social class was the Hatt-North Occupational Prestige Ratings. Many researchers believed the scale to be highly valid because it represented a composite of factors which allowed high predictive power. The major limitation of the Hatt-North scale was that scores were available only for

54 Lloyd W. Warner, and others, "Social Class in America," The Social Matrix of Physical Education (Englewood Cliffs, New Jersey: Prentice-Hall, Inc., 1968), p. 65 .

55 Ibid., p. 35.

56 August B. Hollingshead, Elmtown's Youth (New York: John Wiley and Sons, Inc., 1956), pp. 256-257. 
occupations encompassing less than half of the labor force. 57 The final social class index reviewed was by Duncan who developed a prestige index for the four hundred forty-six occupations listed in the 1950 United States census. A major advantage of the Duncan index was the large number of occupations that were rated. The index also divided the civilian labor force into major occupational groups according to ten deciles of socio-economic status. When determining social class by occupation, a ten-decile breakdown allowed the investigator to be more accurate in describing and pinpointing assorted characteristics to specific social classes. 58

Havighurst supported the theory that occupation can be an adequate index to measure social class and also reported that occupation was the most important single variable for determining social class. 59

THE QUESTIONNAIRE AS A RESEARCH TOOL

The literature reviewed in this section pertained to three basic areas: (1) advantages and disadvantages of the

57 Delbert c. Miller, Handbook of Research Design and $\frac{\text { Social }}{1970)}, \frac{\text { Measurement }}{\text { pp. 169-178. }}$ (New York: David McKay Company, Inc.,

${ }^{58}$ Albert J. Reiss, Jr., Occupations and Social Status (New York: Free Press, 1961), pp. 154-158.

${ }^{59}$ Robert J. Havighurst, Education in Metropolitan Areas

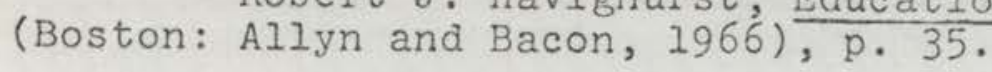


questionnaire, (2) construction of a questionnaire, and (3) criteria for evaluating a questionnaire.

According to Clarke and Clarke, the purpose of a questionnaire is to obtain information from a large number of individuals within a short period of time and without considerable expense. The questionnaire as a research tool should be used only for gathering information that cannot be obtalned in any other reasonable way. 60

Advantages and Disadvantages of the Questionnaire

Mouly reported the major advantage of the questionnaire was that it permitted the investigator to cover a wide area at minimum expense both in money and effort. This greater coverage increases validity in the results through promoting the selection of a larger and more representative sample. ${ }^{61}$ Gorden added another important advantage of the questionnaire, anonymity, which was not possible with the interview. ${ }^{62}$ Kerlinger stated that with most or all items on a questionnaire of the closed type, greater uniformity of stimulus increases

${ }^{60}$ David H. Clarke and H. H. Clarke, Research Processes in Physical Education, Recreation, and Health Education (Englewood Cliffs, New Jersey: Prentice-Hall, Inc., 1970), p. 102.

${ }^{61}$ George J. Mouly, The Science of Educational Research (New York: American Book Company, 1963), p. 240.

${ }^{62}$ Raymond L. Gorden, Interviewing-Stratesy, Technique, and Tactics (Homewood, Illinois: Dorsey Press, 1969), p. 54 . 
the rellability achieved. ${ }^{63}$ In this respect the questionnaire has the advantage of objectivity, assuming that the items are well constructed and pretested.

The literature supported three major advantages of the questionnaire: (I) the investigator can study a large population at minimum expense, (2) anonymity is preserved, and (3) the larger population sample contributes to greater reliability. Mouly stressed three major disadvantages of the questionnaire. ${ }^{64}$ First is the problem of non-returns. This results in decreasing the sample which may introduce a bias inasmuch as non-respondents can hardiy be considered representative of the total population. Second, research shows that respondents tend to have superior intellectual and educational. status, while members of the lower intellectual and educational groups tend not to respond. When individuals in the latter group do respond, they tend to decrease the validity of the instrument by their inability to interpret the questions or to express their responses clearly. Third, there is the possibility that there may be misinterpretations of the questions. Ambiguity due to poor word choices contributes to the confusion. These weaknesses are as much the result of the questionnaire

63 Fred Kerlinger, Foundations of Behavioral Research (New York: Holt, Rinehart and Winston, Inc., 1964), p. 476. ${ }^{64}$ Mouly, op. cit., pp. $241-242$. 
as are the limitations inherent in the method itself.

A number of disadvantages of the questionnaire were reported by Van Dalen: ${ }^{65}$ (1) some subjects may not understand the questions and therefore supply inaccurate responses, (2) respondents may not be free or willing to devulge information, hence lgnoring certain questions or falsifying their answers, (3) many people fill out questionnaires carelessly, and (4) respondents may answer the questionnaire to conform to their biases, to protect their self interests, to please the researcher, or to conform to the norms of soclety.

Constructing the Questionnaire

Clarke and Clarke discussed criterla that should be considered in the construction of a questionnaire as follows: 66 1. The investigator must have proper training and experience to conduct the study. Too often the questionnaire is looked upon as an easy research method. Unfortunately too many investigators fail to realize the skill necessary for constructing a valld and reliable questionnaire.

2. The purpose and objectives of the study must be such that the questionnaire as a data gathering instrument is feasible and appropriate.

${ }^{65}$ Deobold B. Van Dalen and William J. Meyer, Understand$\frac{\text { ing Educational Research (New York: McGraw-Hill Book Company, }}{1966), \text { p. } 301 .}$

${ }^{66}$ Clarke and Clarke, 오. ⒈ ‥, pp. 104-107. 
3. The investigator must be cognizant of the limitations of the questionnaire method. Important considerations are the accuracy of the responses and of the returns. For example, will subjects give honest answers to the questions? Will subjects return the questionnaire?

4. In writing the questionnaire the investigator should outline his area of interest systematically. Broad categories should be identified to avoid overlapping. Questions should be arranged in a logical sequence.

5. Each statement in the questionnaire must be absolutely clear. The success or fallure of the study will depend upon the care and precision taken in developing statements that contain no ambiguities or grammatical errors which may be misleading. The vocabulary used must be appropriate to the population being tested.

6. Questions should be stated so that short answers can be given. The need for extensive answers may discourage the respondent. Long answers also increase the difficulty In summarizing and tabulating responses. If possible, precoding questions should be considered for data processing at the conclusion of the study.

Good summarized six criteria by Scates and Yeomans to be considered in questionnaire construction. 67 The questionnaire

${ }^{67}$ Carter V. Good, Introduction to Educational Research (New York: Appleton-Century-Crofts, Inc., $\frac{1959), \text { pp. }}{198-199 .}$ 
must be short, interesting, not too suggestive; responses should not be mechanically forced or embarasing, and finally; the questionnalre must elicit information that will answer the basic questions for which the questionnaire was designed.

\section{Criteria for Evaluating a Questionnaire}

Mouly developed a checklist to evaluate a questionnaire. ${ }^{68}$ Rephrased in question form, items from the checklist follow:

1. Does the questionnalre deal with a significant topic? Will the questionnaire make an important contribution to the study? Is the questionnaire worthy of professional participation?

2. Is the importance of the problem clearly stated in the statement of the problem and in the cover letter?

3. Does the questionnaire seek only information that is not available elsewhere?

4. Is the questionnaire as brief as the study of the problem will allow?

5. Are directions clear, complete, and acceptable?

6. Are all questions objective and relatively free from ambiguity and other invalidating features. 7. Have questions been checked for any factors that

${ }^{68}$ Mouly, op. cit., p. 263. 
may embarrass the respondent or place him on the defensive?

8. Are the questions in good psychological order?

9. Are the questions so arranged that they can be tabulated and interpreted readily?

Once the questionnaire has been constructed, a pretest is needed. According to Clarke and Clarke the purpose of a pretest is to determine the adequacy of the questions to obtain desired information. 69 During the pretest subjects should be encouraged to detect any lack of clarity and adequacy of the questions. The questionnaire is then revised in accordance with the information received from the pretest. After this phase the questionnaire is usually ready to be administered to the population to be studied.

The literature reviewed in this section noted the advantages and disadvantages of the questionnaire. Common advantages found were low cost, large sample size, and anonymity. Disadvantages mentioned most frequently were non-returns, lack of understanding by the subjects, and carelessness in filling out the questionnaire. Specific components and several lists of criteria for evaluating a questionnaire were also presented.

\section{SUMMARY}

This chapter was a review of research and literature

${ }^{69}$ Clarke and Clarke, op. cit., p. 109. 
related to the problem under investigation and included: (1) a general overview of the development of school health services, (2) criteria and measurement of social class, and (3) the questionnaire as a research tool. Examination of the literature did not reveal any studies concerning social class and its possible influence on school health services. A number of studies indicated there was a link between social class and health services. Therefore, a need to analyze the relationship of soclal class and school health services appears appropriate. Of the research methods available the survey questionnaire seemed most appropriate for gathering data.

In the following chapter a detailed discussion of the procedures used in this study is presented. 


\section{METHODOLOGY}

This investigation was designed to determine parental attitudes toward school health services and the differences that existed among the attitudes of parents from different soclal classes. The research design consisted of: (1) preliminary planning for the study, (2) sampling procedures, (3) procedures for the collection of data, (4) selection of a social class index, (5) construction, pretesting, and distribution of a survey questionnalre, and (6) the statistical procedures used to analyze the data. ${ }^{1}$

\section{Preliminary Planning for the Study}

In the initial phase of the study the author met with Dr. Marion Fleck, Coordinator of Health and Nursing Services. in the Albuquerque Public Schools, to discuss the merit of the proposed study and the possibility of using the Albuguerque Public Schools as a source for subjects.

Formal approval to pursue the study came from the Director of Special Services, Mr. Thomas Lockewood, and the principals of the schools involved in the study.

${ }^{1}$ Many of the procedures utilized were recommended in Charles H. Backstrom and Gerald D. Hursh, Survey Research (Minneapolis: Northwestern University Press, 1963). 
Sampling Procedures

It was important to the study that the participating schools represent three different social class levels: low, middle and upper. To obtain such a coverage the aid of a local school administrator was enlisted. The schools selected were grouped as follows: .

\begin{tabular}{|c|c|c|}
\hline Lower Class" & Middle Class & Upper Class \\
\hline $\begin{array}{l}\text { Pajarito } \\
\text { Coronado } \\
\text { Duranes }\end{array}$ & $\begin{array}{l}\text { Inez } \\
\text { Monte Vista } \\
\text { Carlos Rey }\end{array}$ & $\begin{array}{l}\text { Chelwood } \\
\text { Acoma } \\
\text { Comanche }\end{array}$ \\
\hline
\end{tabular}

The parents of children in these nine selected schools served as the population for this study. Approximately 5,370 children were enrolled in the nine schools. The approximate total number of families represented by these children was 3,035 .

Procedures for Collection of Data

Mr. Lockewood made the initial contacts with the principals to inform them about the study. The investigator then scheduled conferences with each of the principals during which pertinent features of the proposed study were explained. Discussions centered on: (1) the purpose of the study, (2) ways in which the information would be used, (3) the selection of subjects, and (4) the method of collecting data. By the end

* Lower class schools were determined from Title I classifications. 
of January, 1971, all principals contacted had approved the study.

Selection of a Social Class Index

The social class stratification index, developed by Duncan was used in this study. This index was designed to measure social class status by dividing occupations into deciles. ${ }^{2}$ The following decile rankings applied to the present study:

\section{Dec1le Rankings}

$\begin{array}{ll}\text { Lower Class } & 1-4 \\ \text { Middle Class } & 5-8 \\ \text { Upper Class } & 9-10\end{array}$

Construction of the Questionnaire

Data was collected by a questionnalre. This research instrument, the survey questionnaire, was used because it permitted investigation of a large sample from the population being analyzed and afforded anonymity to the respondents in the study.

Three major sources were consulted in preparation for constructing the items on the questionnaire. First, the review of literature revealed a number of questions concerning particular school health services that parents wanted for their

${ }^{2}$ Albert J. Reiss, Jr., Occupation and Social Status (New York: Free Press, 1961), pp. 154-158. 
children. Second, Dr. Fleck suggested several questions regarding school health services that needed to be answered, and third, other members of the investigator's doctoral committee recommended a number of possible questions to be included in the questionnaire to elicit useful information.

Since the responses to the questionnaire came from parents of varying educational backgrounds, it was necessary to adapt the vocabulary to a level appropriate for all participants. An effort was made to stay within the fourth grade vocabulary. This was verified by Rinsland's text, A Basic Vocabulary of Elementary School Children. ${ }^{3}$

Format of the Questionnaire

The questionnalre ${ }^{4}$ consisted of twenty items stated so as to elicit one response from four possible answers: (I) Yes, (2) Sometimes, (3) No, and (4) Don't Know. Three of the 1 tems on the questionnaire asked parents to respond with check marks. The questionnaire concluded with a general question that invited parents to express their feelings and ideas about school health services. Space for additional comments was also provided. Since Coronado Elementary School was identified as a school with a high percentage of Spanish speaking parents,

3 Henery D. Rinsland, A Basic Vocabulary of Elementary School Children, (New York: MacMillan Company, 1945). ${ }^{4}$ The questionnaire is reproduced in Appendix A. 
the questionnaires distributed through that school were translated into Spanish. The Spanish version, prepared by Mr. Eugene Romo and later modified by the Coronado principal, Mr. Carlos Saavedra, conformed to the vernacular of the Spanish speaking parents in the Coronado Elementary School area. These parents recelved two questionnaires, one in English and one in Spanish. Pupils were asked to have their parents complete either one but not both of the questionnaires. Pretesting the Questionnaire

Thirty parents of elementary school chlldren in the Albuquerque Public School system volunteered to participate In a pretest of the questionnalre. Each was asked to respond as indicated to the questionnaire and to assess the instrument in terms of the following criterla:

1. Are the directions clear?

2. Are the questions objective and free from ambiguity?

3. Do the questions elicit reliable and accurate information?

4. Are there any mechanical errors in the format?

Errors in sentence structure and ambiguities discovered in the pretest were corrected before the questionnaire was sent to the printer to be duplicated into finished form.

The questionnaire was also examined several times by . the investigator's doctoral committee. Recommendations by 
the doctoral committee were incorporated into the instrument. Distribution of the Questionnaire

Each principal was consulted to determine the best method for distributing the questionnaires in his school. To avold duplicate responses from parents with more than one child in the same school, dual plans were followed: All first graders recelved a questionnaire, and all children in grades two through six were told not to take one if they had a brother or sister in a lower grade. The other distribution plan was one in which the principal reversed the procedure starting with the sixth grade and moving down to the first grade. The problem of having two questionnaires going home to one family was further minimized by advising the classroom teacher to issue only one questionnaire per family. Directions read by the classroom teachers to the students were: "Please take this questionnaire home. Have one or both of your parents fill the questionnaire out. Return the questionnaire to your teacher tomorrow."

Questionnaires were delivered to the schools one week before they were to be distributed. All questionnaires were issued on Monday or Tuesday of the following week. The actual distribution of the questionnaires was as follows: In five schools the investigator took the questionnaires to the principal where they were distributed by the school 
secretary. For three schools the investigator prepared packets and delivered them to each teacher. In one school the writer delivered the questionnaires to each classroom. Completed questionnalres were returned to the principal's secretary one week after the distribution.

Tardy returns were collected by the school secretaries and held for the investigator. Some were malled to Dr. Fleck and collected by the investigator.

\section{ANALYSIS OF DATA}

\section{Statistical Procedures}

To analyze the data four procedures were used: (1) classification of parents into three social classes using Duncan's Social Class Index, (2) calculation of frequency distributions to determine how parents answered each item on the questionnaire, (3) cross tabulation to determine the number of parents responding to items on the questionnaire within each social class decile, and (4) chi square was applied to the responses in order to determine the existence of any differences in responses from parents representing three soclal class groups.

SUMMARY

This chapter included a description of the subjects, how they were selected, the questionnaire used and the 
statistical tools to analyze the data. An analysis of the data follows in Chapter IV. 
Chapter IV, the analysis and discussion of the data, is divided into four major sections: (1) analysis of questionnaire items by frequency distribution, (2) analysis by social class, (3) analysis of the data by cross tabulation and chi square, and (4) discussion of the two hypotheses and one major question.

\section{TREATMENT OF THE DATA}

of the 3,035 questionnaires distributed, 2,533 (83 per cent) were completed and returned (See Appendix C, Table 1). According to Backstrom and Hursh ${ }^{1}$ this gave a two per cent tolerated error. This means that any score in the sample was within two points of the true score of the population. A score of 80 could, therefore, deviate only within a four point range from 78 to 82 .

The first step in analyzing the data was to categorlze the questionnaires according to the social class level of the respondents. This was accomplished by using Duncan's Social Class Index (Appendix B). Next a frequency distribution of

\section{${ }^{l}$ Charles H. Backstrom and Gerald D. Hursh, Survey}

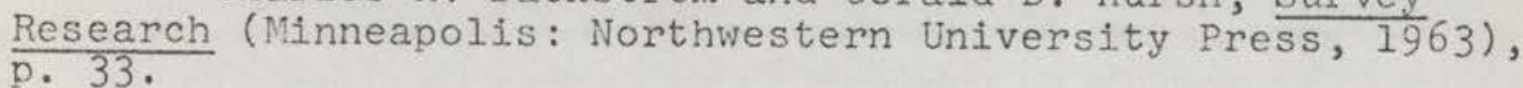


parent responses from each school to each item on the questionnaire was made (Appendix C, Table 4). The author then set up a frequency distribution for the total sample and converted raw scores into percentages (See Appendix C, Table 2).

Frequency Distribution

The questionnaire used in this study provided four possible responses for each of thirty-three items. Four 1tems $(N, R, S$, and $T$ ) asked parents to respond with check marks. Yes-No responses, tallied in Table 2, were analyzed in Table 3. Certain school health services that appeared to be approved most frequently by parents were indicated in Table 3 .

\section{TABLE 3}

PERCENTAGES OF YES-NO RESPONSES FOR EACH QUESTIONNAIRE ITEM

\begin{tabular}{|c|c|c|c|c|}
\hline Item & Question & Yes & No & Difference \\
\hline & & $\%$ & 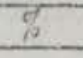 & 3 \\
\hline A & $\begin{array}{l}\text { Should first ald at your } \\
\text { child's school be done only } \\
\text { by the school nurse? }\end{array}$ & 31 & 46 & $15(-)$ \\
\hline B & $\begin{array}{l}\text { Should the school nurse } \\
\text { be the only adult to work }\end{array}$ & & & \\
\hline & in the school health room? & 23 & 62 & $39(-)$ \\
\hline $\mathrm{c}$ & $\begin{array}{l}\text { Should the school nurse } \\
\text { help you make arrangements } \\
\text { to get health treatment }\end{array}$ & & & \\
\hline & for your child if needed? & 69 & 12 & 57 \\
\hline D & $\begin{array}{l}\text { Should the school nurse } \\
\text { talk to other people } \\
\text { (custodian, bus driver, }\end{array}$ & & & \\
\hline
\end{tabular}




\section{TABLE 3 (continued)}

\begin{tabular}{|c|c|c|c|c|}
\hline Item & Question & Yes & $\frac{\text { No }}{\%}$ & $\frac{\text { Difference }}{\%}$ \\
\hline & $\begin{array}{l}\text { etc.) about the health } \\
\text { needs of children such as } \\
\text { clean bathrooms, and safety } \\
\text { in the school and on the } \\
\text { bus? }\end{array}$ & 77 & 9 & 68 \\
\hline E & $\begin{array}{l}\text { Should the school nurse } \\
\text { teach classes about } \\
\text { health? }\end{array}$ & 77 & 6 & 71 \\
\hline F & $\begin{array}{l}\text { Should the school nurse } \\
\text { teach classes about sex } \\
\text { education? }\end{array}$ & 50 & 13 & 27 \\
\hline G & $\begin{array}{l}\text { Should the school nurse } \\
\text { teach classes about drug } \\
\text { education? }\end{array}$ & 64 & 13 & 51 \\
\hline $\mathrm{H}$ & $\begin{array}{l}\text { Should the school nurse } \\
\text { help with inspections of } \\
\text { the bathrooms, playground, } \\
\text { and cafeteria of the } \\
\text { school? }\end{array}$ & 66 & 14 & 52 \\
\hline I & $\begin{array}{l}\text { Should the school nurse } \\
\text { make safety inspections of } \\
\text { the gym, playground and } \\
\text { other school areas? }\end{array}$ & 47 & 28 & 19 \\
\hline $\mathrm{J}$ & $\begin{array}{l}\text { Should the school nurse } \\
\text { be the only one to record } \\
\text { health information on } \\
\text { your child's health record? }\end{array}$ & 57 & 32 & 25 \\
\hline K & $\begin{array}{l}\text { Should the school nurse } \\
\text { be the only one to see your } \\
\text { child's health record? }\end{array}$ & 23 & 63 & $40(-)$ \\
\hline L & $\begin{array}{l}\text { Should the school nurse } \\
\text { talk to you when your } \\
\text { child needs shots, } \\
\text { (immunization)? }\end{array}$ & 85 & 7 & 78 \\
\hline
\end{tabular}


TABLE 3 (continued)

\begin{tabular}{ccccc} 
Item & Question & Yes & No & Difference \\
\hline M Should the school nurse & \% & $\%$ & $\%$ \\
\cline { 3 - 5 } & share information about & & & \\
your child's health with & & & \\
the & & & \\
M1 Teacher & 70 & 2 & 68 \\
M2 Principal & 61 & 3 & 58 \\
M3 Counselor & 56 & 3 & 53 \\
M4 You & 94 & 0 & 94
\end{tabular}

N Should the school nurse test your child for $\begin{array}{ll}\text { N1 } & \text { Vision } \\ \text { N2 } & \text { Hearing } \\ \text { N3 } & \text { T.B. }\end{array}$

- Should the school nurse have a health talk (conference) with your child at least once a year?

$P$ Would a talk with the school nurse about your child's health be of value to you?

Q Does the school nurse spend enough time at your child's school?

Ri. Have you ever met the school nurse? If yes, please check where

R2 At home

R3 At school

R4 Telephone call

R5 other

16
7
31
14
3

40
1
0
0
0

24
6
31
14
3

$S$ Who calls you from school when your child is sick or injured? Please check:
SI School nurse
S2 Teacher
S3 Principal 
TABLE 3 (continued)

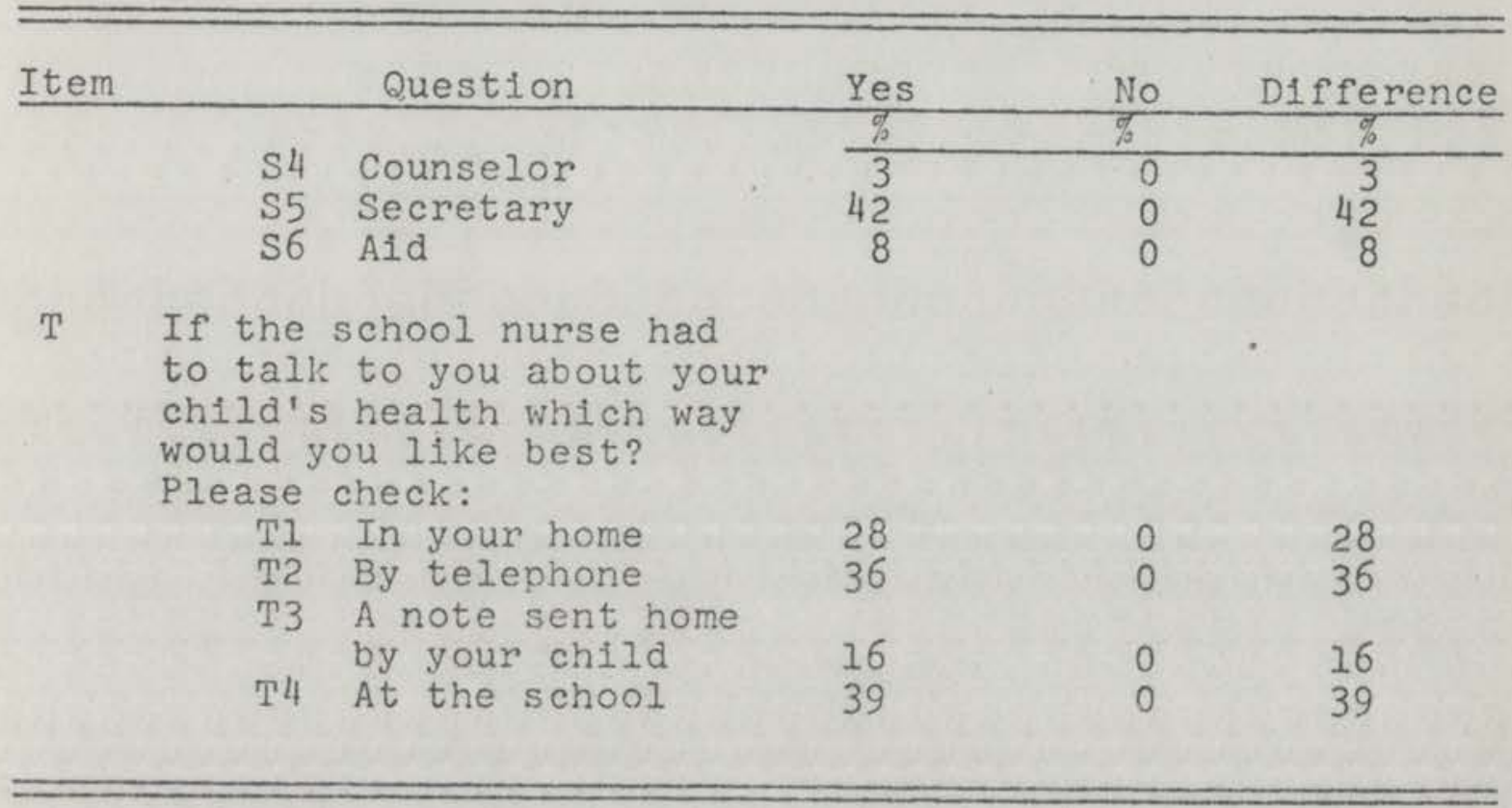

Only five of the thirty-seven items on the questionnalre were not supported by parents as illustrated in the following figure.

\begin{tabular}{|c|c|c|c|}
\hline \multirow[b]{2}{*}{ Item } & \multicolumn{2}{|c|}{ Responses } & Differences \\
\hline & Yes & No & In Per Cent \\
\hline K & 23 & 63 & $40(-)$ \\
\hline B & 23 & 62 & $39(-)$ \\
\hline RI & 16 & 40 & $24(-)$ \\
\hline Q & 12 & 28 & $16(-)$ \\
\hline A & 31 & 46 & $15(-)$ \\
\hline
\end{tabular}

Figure 1. Percentages of Yes-No responses for five items that were not supported by parents. 
Although these five items are not health services in the usual sense, such as vision and hearing testing, the items are indicative of practices of school nurses that have usually been acceptable and wanted by parents. These percentages indicated that parents favored other people being allowed to see their children's health records (Item $K$ ). Respondents felt that the school nurse should not be the only one to work in the school health room (Item B). Approximately forty per cent of the parents responding to the questionnaire had not met the school nurse (Item RI). Parents would like to have the school nurse spend more time at school (Item Q). Finally, the school nurse should not be the only one responsible for providing first aid for school children at school. (Item A). In summary, parents did not support five practices by school nurses. However, the data indicated strong parental support for most of the practices and health services presently provided by the school nurse.

As an adjunct to this study an administrator in the Albuquerque Public Schools subjectively grouped participating elementary schools into three social class strata, low, middle, and upper. Tables $1-9$ in Appendix D presented the social class stratification by Duncan's ten decile social class index of the parent population for each school. A summary of parents' responses to the questionnaires by social class and school appears in Table 5. 


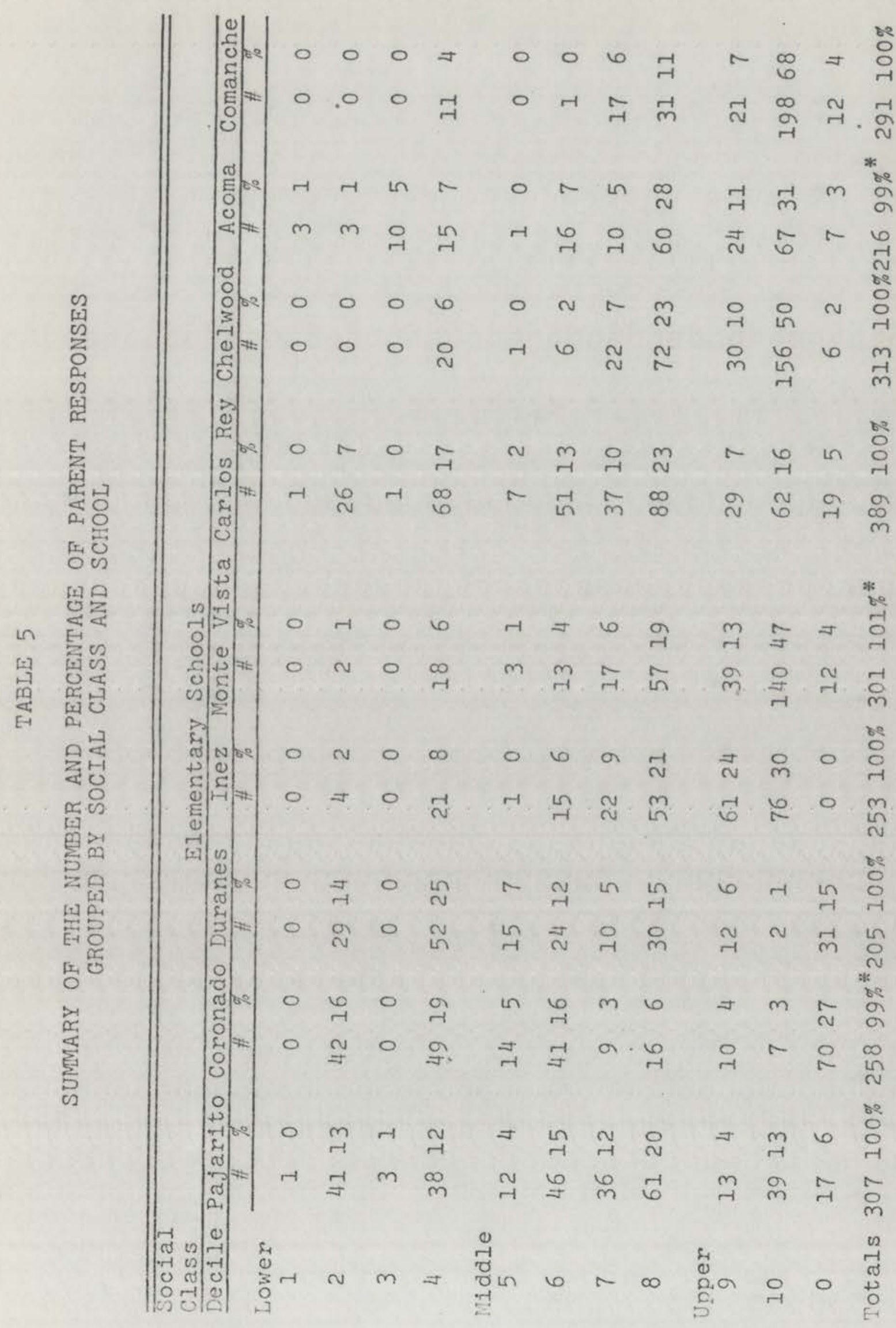


Tables 1-9 in Appendix D indicated that Pajarito had a middle class parent population although it was originally predicted to be lower class. The prediction that Coronado parents were lower class was supported. Duranes parents were predicted to be lower class, yet they were found to be between the lower and middle class.

Parents from Inez and Monte Vista were predicted to be middle class, but data revealed that they were in the upper class. Carlos Rey parents were found to be in the middle class as predicted.

According to Appendix D, Chelwood, Acoma, and Comanche parents were all upper class as predicted. Acoma parents, however, were only two percentage points from being classifled in the middle class.

These data suggested that subjective predictions concerning the social class of parent populations within schools may be misleading.

The Null Hypotheses

Hypothesis I: There are no significant differences in the attitudes of parents from different social classes toward school health services.

In each of the nineteen chi square matrices there was parent support from all three social classes for all but three items tested $(A, K$, and $R I)$. The degree of support for the 
items, however, was different between each social class. This difference was at the .001 level of significance in eighteen cases and .02 in one case. This suggested that parents from different social classes supported school health services in varying degrees.

The significance of differences revealed by the data from cross tabulation was determined by chi square. The specific purpose of the chi square treatment was to determine If the actual differences in parental expectations of school health services were significantly different.

All items on the questionnaire were subjected to a chi square test at or below the .02 level of significance. Only those items that were significant at this level appear in Table 6. The degree of variance between observed and expected frequencies in social class is shown in this table. The chi square matrices that were significant appear in Appendix E.

Table 7, page 59, 1llustrates the degree of support, significant at the .02 level of confidence, that each social class gave to the nineteen 1tems. The degree of support for each item by low, middle, and upper social classes was divided into four categories: (1) strongly approved, (2) approved, (3) disapproved, and (4) strongly disapproved.

Strongly approved. Fifteen items were strongly approved 


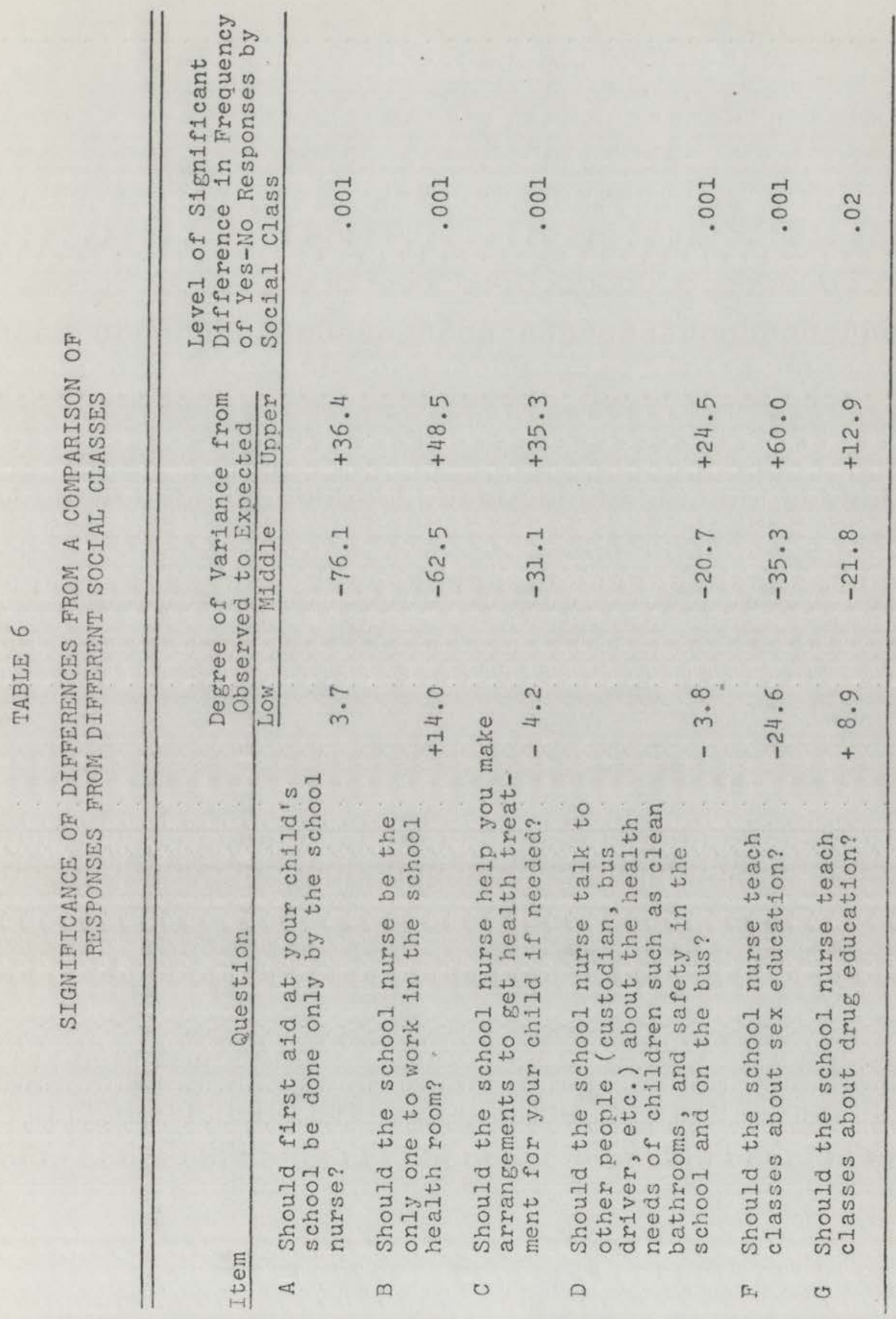




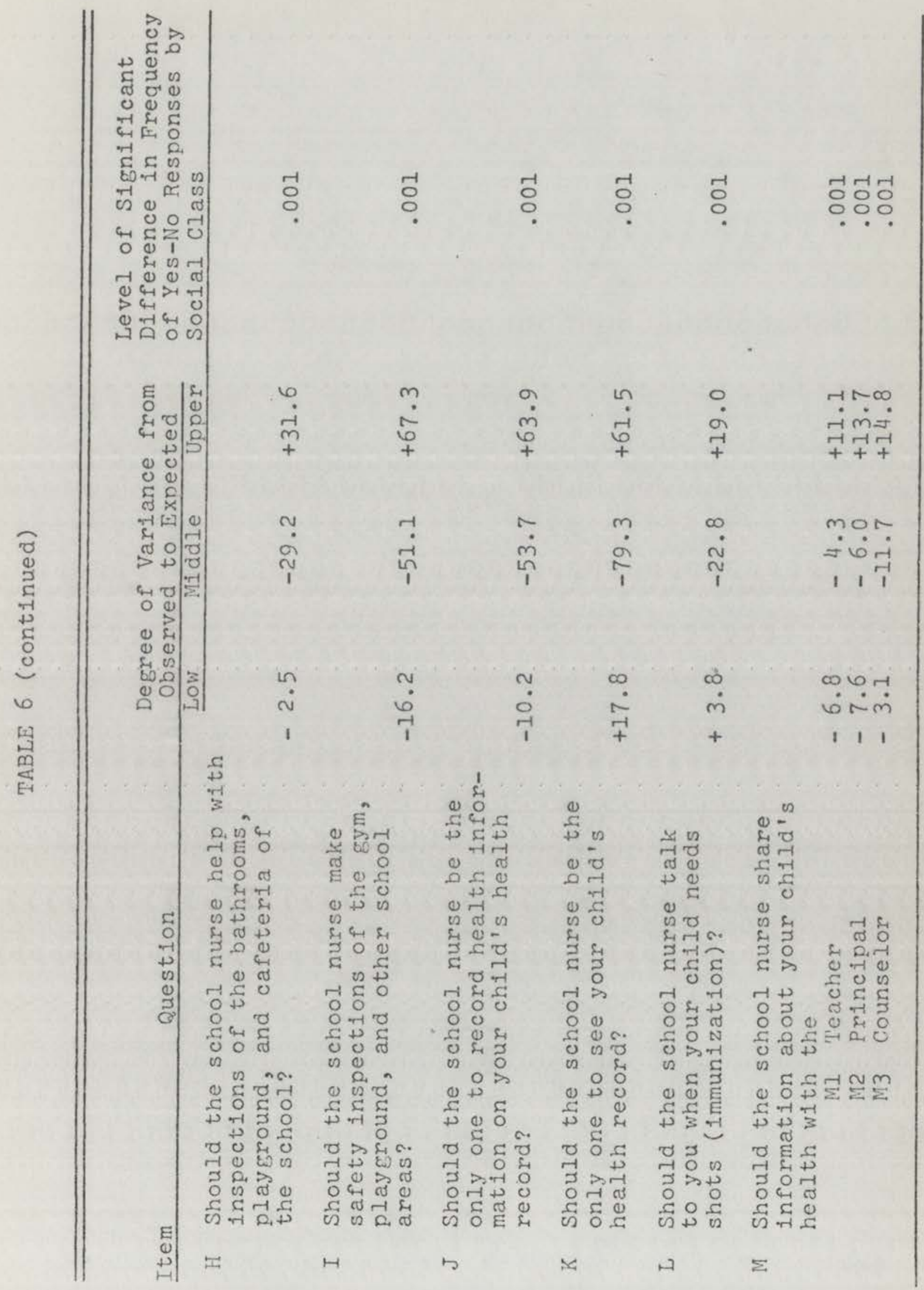




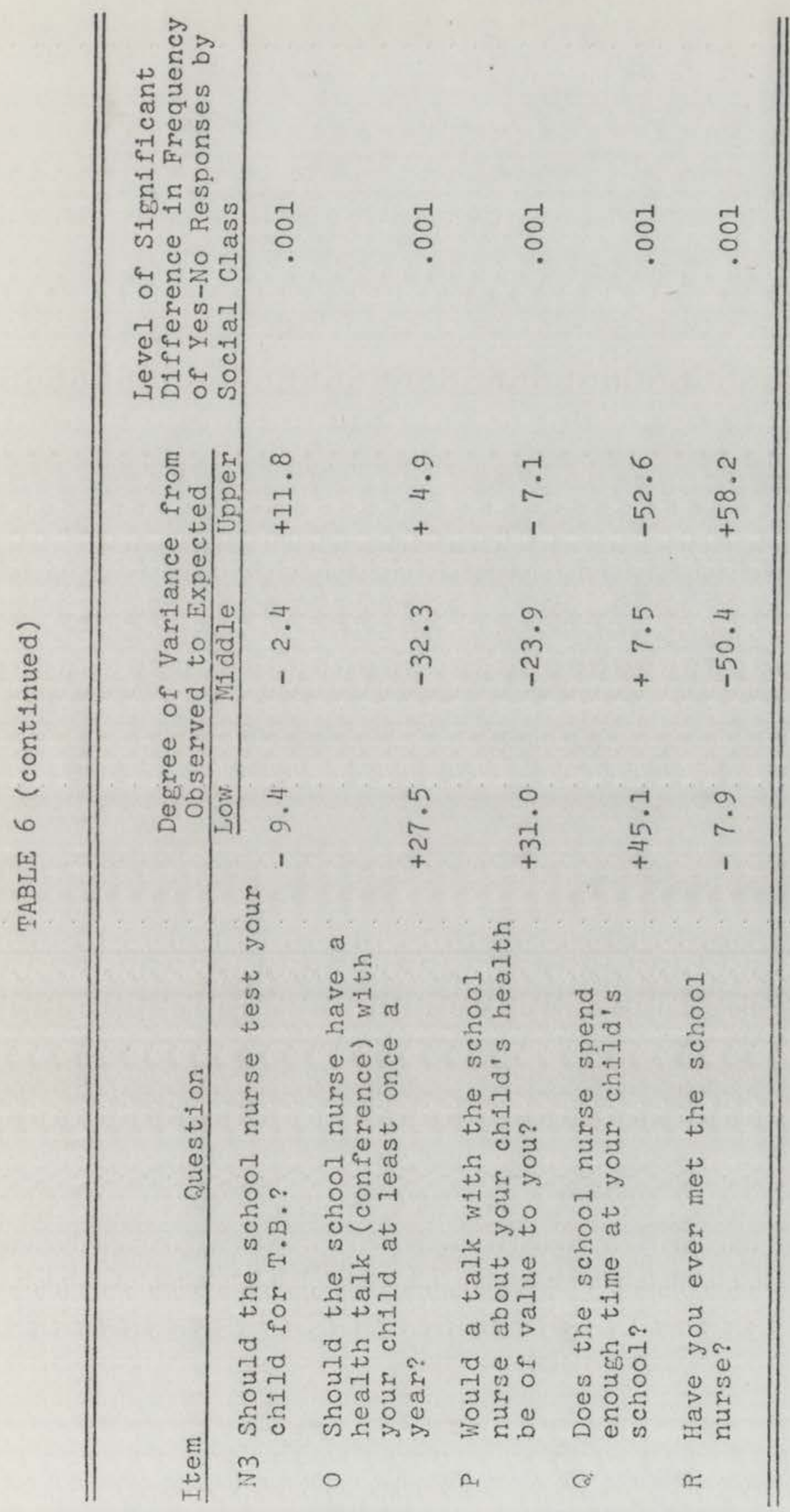




\section{TABLE 7}

CLUSTERS OF SCORES INDICATING THE DEGREES OF SUPPORT FOR SCHOOL HEALTH SERVICES BY PARENTS OF THREE SOCIAL CLASSES

\begin{tabular}{|c|c|c|c|c|}
\hline Social Class & $\begin{array}{l}\text { (1) } \\
\text { Strongly } \\
\text { Approved }\end{array}$ & $\begin{array}{c}\text { (2) } \\
\text { Approved }\end{array}$ & $\begin{array}{c}\text { (3) } \\
\text { Disapproved }\end{array}$ & $\begin{array}{l}\quad \text { (4) } \\
\text { Strongly } \\
\text { Disapproved }\end{array}$ \\
\hline Upper Class & $\begin{array}{ll}\text { A, } & H, M 1 \\
C, & I, M 2 \\
D, & \text { I, } 33 \\
\text { F, } & \text { N3 } \\
\text { G, L, } & \text { RI }\end{array}$ & $\begin{array}{l}0 \\
P \\
B\end{array}$ & B & Q \\
\hline Middle Class & & $\begin{array}{ll}\mathrm{C}, & \mathrm{I}, \mathrm{M} 3 \\
\mathrm{D}, \mathrm{J}, \mathrm{N} 3 \\
\mathrm{~F}, \mathrm{~L}, \mathrm{O} \\
\mathrm{G}, \mathrm{MI} \\
\mathrm{H}, \mathrm{M}\end{array}$ & $\begin{array}{l}Q \\
R 1\end{array}$ & $\begin{array}{l}A \\
B \\
K\end{array}$ \\
\hline Lower Class & & $\begin{array}{ll}A, G, & M I \\
B, H, & M 2 \\
C, I, & M 3 \\
D, & J, \\
F, I, & \end{array}$ & $\begin{array}{l}K \\
B \\
Q\end{array}$ & \\
\hline
\end{tabular}


by the upper class whereas the lower and middle class did not strongly approve any item.

Approved. The upper class approved three items while the middle and lower class approved fourteen and thirteen items respectively.

Disapproved. The upper class disapproved of one item, the middle class two 1tems and the lower class three items.

Strongly disapproved. Upper class parents strongly disapproved one item, middle class parents three items, and lower class parents no items.

From this data it is evident that parents from all three social classes approved and supported all but three of the items ( $A, K$, and $R I$ ) represented in the questionnalre. Analysis of these three items follows:

Item A: Should first aid at your child's school be done only by the school nurse?

This item was approved by lower class parents, strongly approved by upper class parents, but opposed by middle class parents.

Item K: Should the school nurse be the only one to see your child's health record?

The data revealed that the lower and middle classes approved of individuals, other than the school nurse seeing 
their children's health records. The upper class parent, however, strongly disapproved this concept.

Item RI: Have you ever met the school nurse?

The numbers of parents who had met the school nurse were greatest in the upper class; next in frequency came the lower class; middle class parents ranked the lowest on this 1tem. When parents were asked where they had met the school nurse they responded as follows in descending order: at school, 31 per cent; telephone call, 14 per cent; and at home, 7 per cent.

Analysis of Table 8 revealed that the upper and lower social classes were almost mirror images of each other when particular items were compared from the strongly approved to the approved categories. Also, the varying degree of difference in approval of certain school health services by the lower and upper class parents was iliustrated in this table.

From this the author suggested that there is definitely a difference in the degree that certain school health services are expected by parents from different social classes. This tendency continued to exist when the middle class strongly disapproved and lower class disapproved categories are compared (Table 9).

The majority of items responded to by midale class parents clustered under approved categories, which is where most items clustered for lower class parents. This indicated 
TABLE 8

A LIST OF HEALTH SERVICE ITEMS WHICH ILLUSTRATE

THE VARYING DEGREE OF APPROVAL BETWEEN UPPER AND LOWER CLASS PARENTS

\begin{tabular}{cccc}
\hline $\begin{array}{c}\text { Upper } \\
\text { Strongly }\end{array}$ & $\begin{array}{l}\text { Loproved } \\
\text { Approved }\end{array}$ & $\begin{array}{c}\text { Lower } \\
\text { Approved }\end{array}$ \\
\hline A & K & A & - \\
C & L & C & L \\
D & MI & D & MI \\
F & M2 & F & M2 \\
G & M3 & G & M3 \\
H & N3 & H & N3 \\
I & RI & I & - \\
J & & J & \\
\hline
\end{tabular}

TABLE 9

A LIST OF HEALTH SERVICE ITEMS WHICH ILLUSTRATE THE VARYING DEGREE OF DISAPPROVAL BETUEEN MIDDLE AND LOWER CLASS PARENTS

Middle Class Strongly Disapproved

A

B

K
Lower Class

Disapproved

$\begin{array}{ll}A & Q \\ B & B \\ K & K\end{array}$


that lower and middle class parents were similar in the health services they desired.

The present research found responses to nineteen items that were significant at the .02 level of significance. Each of these items showed variability in the attitudes of parents from three different social classes toward school health services. Null Hypothesis I can, therefore, be rejected.

\section{Hypothesis II: There are no significant differences}

in the kinds of school health services wanted by parents from different social classes.

of thirty-seven items tested by chi square only two were rejected by parents from one of three soclal classes. The first item (Item A) pertained to who should administer first ald. The middle class felt that the school nurse should not be the only one responsible for this service. The second item (Item K) concerned whether or not the school nurse should be the only one to see their children's health records. Only the upper class opposed this item. These findings supported parents from different social classes not expecting different kinds of school health services. Hence, Hypothesis II is not rejected.

Major Question

A major question to be answered by this study was: What specific health services do parents from different social 
classes want the school to provide for their children?

To answer this question the author grouped the written comments made by parents at the end of the questionnaire into four categories: (1) health services wanted by all social classes, (2) health services wanted only by the lower class, (3) health services wanted only by the middle class, and (4) health services wanted only by the upper class. Following are comments written on the questionnaire.

Health Services Wanted by All Soclal Classes

1. The school nurse should be at school more often.

2. The school nurse does an excellent job.

3. I am not familiar with the school health services provided by the school nurse.

4. The school nurse should be allowed to administer aspirin.

5. Would like children to receive all necessary immunization from the school.

Health Services Wanted Only by the Lower Class

1. Check children's teeth.

2. Check children's hair for dirt and Iice.

3. Teach children first aid procedures.

4. Would like the school to provide a doctor to give children medical examinations.

5. The school nurse should teach children clean health habits.

6 . The school nurse should help pay for eye glasses if needed.

Health Services Wanted Only by the Middle Class

1. Hire someone to check the mental health of children.

2. Keep the rest rooms cleaner.

3. Would like to personally meet the school nurse.

4. Get more volunteers to help the school nurse.

5. The school nurse should teach good grooming. 
Health Services Wanted Only by the Upper

1. Health education should be stressed.

2. Need more school nurses.

3. Expand the school nursing program.

4. Faculty members should be taught first aid.

5. More supervision by the school nurse on the playground.

6. The school nurse is completely useless.

Nineteen per cent of the parents who returned questionnaires made written comments concerning school health services. These comments were categorized so as to indicate a number of school health services that parents from low, middle, and upper social classes want.

The importance of knowing what school health services are wanted by parents from different social classes is lllustrated in the following hypothetical situation. Nurse Jones worked in a lower class school for the past ten years. Her performance during this time was excellent according to her superiors. As a school nurse in a lower class school, Mrs. Jones periodically checked the children's hair for lice. Hence when she was transferred to a new school located in an upper class district she implemented similar procedures. The very next day after she began this procedure there were numerous complaints by parents asking the principal what school nurse has the gall and audacity to examine their children's hair for lice! As a result, the principal requested Mrs. Jones to cease such inspections. Mrs. Jones replied, "For the past ten years I have checked children's hair for lice 
and never once had a complaint. I can't understand why parents all of a sudden object to this service."

The material presented in this chapter provided clear indicators of why Mrs. Jones was criticlsed by the school principal.

\section{SUMMARY}

The analysis of the data yielded several significant findings. First, subjective assessment of social class can be misleading; second, parents from all social classes supported school health services; third, social class of parents does make a difference in the school health services wanted for children; fourth, from the items tested by chi square 1t was evident that parents in general were in agreement on what health services should be provided for their children; and fifth, written comments by parents revealed that in each social class, low, middle, and upper, there were a number of different health services expected that were not provided at the time of this survey. 


\section{. CHAPTER V \\ FINDINGS AND RECOMMENDATIONS}

This chapter presents a general discussion of the findings and recommendations based upon the present research.

\section{FINDINGS - SCHOOL HEALTH SERVICES}

This study plus the many references in the review of literature showed that school health services were considered by parents to be a vital function of the school. The responses of parents to questions about the present health services in the schools indicated to the author continued public support for these programs.

Data revealed that parents felt the school nurse should not be the only individual to work in the school health room. Perhaps other individuals such as parents and students could be trained to perform non-technical tasks in order to allow the school nurse more time to provide true nursing services.

Parents wholeheartedly approved the 1 dea that the school nurse should notify them when their children needed immunization for protection against specific diseases. They also wanted the nurse to help them find medical treatment when necessary. Screening programs by the school nurse for vision, hearing, and tuberculosis were vigorously supported 
by parents. Sanitary, and safety inspections of the bathrooms, playground, cafeteria, gymnasium, and other school areas were also considered by the parents to be functions of the school nurse. These findings suggested that the school nurse was expected to provide a multitude of health services as well as to function in supervisory capacities.

Data revealed that most parents do not consider health information about their children to be highly confidential. They want this information and also think that other school personnel should have access to it for the greatest benefit to their children.

The parents also thought that the nurse should handle health education, including sex education and drug information. This indicates a continuing attitude on the parts of parents that the school nurse is knowledgeable in medicine and, therefore, must be competent in teaching sex and drug education.

It is quite likely that many school nurses have neither the time nor the inclination to accept this added responsibility. In addition they may feel completely inadequate in classroom techniques.

Parents on the other hand are perplexed by the extent and the intensity of the problems inherent in drug use and abuse as well as changing ideas about sex. Thus they want and need someone who can provide accurate sex and drug information for their children. 
The need for qualified health educators has never been greater, the kind of informed individuals with a genuine concern for, and interest in, children and young people along with the ability to communicate effectively with them and with their parents. No longer should the nurse be expected to carry the full burden of school health, despite the fact that parents expected her to teach health classes, particularly in drug and sex education. This study provided rather strong evidence that school nurses might obtain additional training in health education if they want to take on this responsibility. At the present time their educational preparation does not prepare them adequately for this expectation by parents.

According to the parents surveyed, the nurse should spend more time at school. At the present time there are thirty-eight full time school nurses to serve the one hundred eight Albuquerque Public Schools. To meet the request by parents for more nursing time, additional nurses will have to be employed.

Answers to the question of who from the school calls the parents about a sick or injured child indicated that in most cases it was the secretary, next in frequency was the nurse, then the principal, the teacher, or an aide. Least likely to call was the counselor. Such findings might mean that the secretary who makes 42 per cent of the phone calls probably provides a certain degree of the health care at school 
because the school nurse is not there every day. Almost half ( 40 per cent) of the 2,533 parents respondIng to this questionnaire had never met the school nurse. of those who had met her, 31 per cent did so at school, 14 per cent met her by telephone, and only 7 per cent became acquainted with the nurse through a home visit. This is ample evidence of the need to strengthen the communication between the school nurse and the parents. There is also the implication that the school nurse may be handicapped in knowing what health services parents want for their children when she has not even met 40 per cent of the parents.

The need for a student-nurse conference at least once a year was advocated by parents. Parents also felt that a parent-nurse conference would be valuable to both parent and child. The author feels that child-nurse and parent-nurse conferences would be very helpful in providing the school nurse with insights into the diverse needs of children and parents. Finally, parents indicated that if the school nurse had to talk to them about their children's health they wolld prefer to do this at school rather than by telephone, a home visit, or a note sent home by their child.

The preceding discussion of what parents want from the school health service raised the question of who was responsible for providing all the health services that parents wanted. Is this the responsibility of the school or the 
responsibility of community health agencies?

At the present time the school is trying to supply health services through school nursing services. However, to supply all the health services that parents have indicated they wanted is well-nigh impossible because of financlal and personnel shortages. Financial support for the present comprehensive health service program is vital. School personnel and parents must join forces in deciding whether or not the schools can provide the magnitude of school health services indicated by this study. Lack of community support may indicate that the school personnel will need to expand education to educate people about other sources of health services. Solutions are imperative if the school administration and school nursing service are to know how to guide and develop their respective programs.

\section{FINDINGS - THE INFLUENCE OF SOCIAL CLASS} ON SCHOOL HEALTH SERVICES

The pivotal variable in this study has been the possible influence of social class on school health services. One must be cognizant that the parent population used in this study consisted of three social class strata, low, midale, and upper. The preceding discussion of school health services exemplified the support of parents for school health services. However, it is extremely important to determine if parents 
from different social classes: (1) have the same attitudes toward school health services, and (2) do parents from different social classes want different kinds of school health services for their children?

The nature and scope of this study concerning social class and its influence on school health services led to several important findings. Positive as well as negative responses of parents from different social classes toward school health services were noted.

Support of parents for health services was found in all three soclal classes but in varying degrees. The degrees of acceptance of certain health services were significant because these differences indicated a need for greater awareness on the part of school and health personnel that parents from different social classes wanted certain health services for their children more than other health services. For example, the support of the upper class for sex education classes in the schools indicated to the writer that the implementation of a sex education program in Albuquerque Public Schools should begin in upper class schools rather than in lower class schools where parental approval was less evident.

The reaction of parents to sex education may have been a manifestation of inherent factors within the divergent make-up of social class. Individuals from different social 
classes have different behavior patterns and attitudes which cause Individuals to look at school health services differently. Therefore, another implication of this finding, in the opinion of the writer, was that parents of the lower class may not have been aware of the need for such a program. Thus some type of program to teach them about the need for sex education should be initiated, preferably by a health educator. Middle class parents were not concerned about who gives flrst aid. In all probability they are more concerned that first aid be given promptly and properly. Perhaps this flnding implies a desire by middle class parents to be involved in the activities of the school, or that other school personnel such as teachers and secretaries should be trained to administer proper first aid.

It was interesting to note that upper class parents wanted only the nurse to see their children's health records. In contrast, the middle and lower class parents considered this matter of confidentiality of no particular importance. This may be partially explained by the upper classes distinctive pattern of life which moves them towards exclusiveness, keeping business and personal affairs within the family. Therefore, upper class parents may strongly resent people other than the nurse seeing their children's health records.

The writer is unable to explain why middle class parents have no objections to other people seeing their children's 
health records. However, responses by lower class parents may be explained by Roach, Gross, and Gursslin in their statement, ${ }^{1}$ ". . lack of proper medical care are the significant facts of life. Marginal and erratic income forces these people to live on a day-to-day basis and rely heavily on public welfare." Thus, the lower class parents may be so accustomed to having their personal affairs examined by public institutions, such as the school, that they give no thought to the use of information available in the records.

In the opinion of the writer, an accurate assessment of the social class of parents from any given school is a necessary prelude to providing adequate health services. Subjective assignment to a given social class was shown by this study to be highly inaccurate. This means that reliable and valid measures must be used to determine the social class of the clientele for which health services are to be provided.

Social class definitely influences the attitudes of an individual, including the school nurse. It might be profitable to determine the effect of social class background on the attitude of the school nurse in delivering school health services.

The rejection of the first hypothesis supported the

${ }^{1}$ Jack L. Roach, Llewellyn Gross, and Orville R. Gursslin, Social Stratification in the United States (Englewood Cliffs, New Jersey: Prentice-Hall, Inc., 1969), p. 199. 
notion that parents from low, middle, and upper social classes perceive school health services differently. This finding suggested that school health service personnel must consider the varying health service needs of the population they serve. Accepting the second hypothesis supported the concept that parents from low, middle, and upper social classes do not want different health services for their children. This finding supports the continued delivery of the health services that were tested in the survey questionnaire used for this study.

The major question answered in this study revealed that there were certain nursing services in each social class that parents wanted the school nurse to provide that were different from those wanted by parents in the other social classes. For example, the lower class parent wanted their children to be checked for such things as tooth decay, dirty hair, and lice. Middle class parents wanted someone to observe the mental health of their children and to teach proper grooming. Upper class parents wanted health education to be stressed and the school nursing program expanded.

RECOMMENDATIONS

As a result of this study the author recommends the following:

1. Efforts of school health personnel should extend 
Into the school neighborhood so that parents as well as children may be better informed about the health functions of the school.

2. Methods of communication between the school and the homes must be improved.

3. School systems should develop health service programs that meet the specific needs and expectations of all families regardiess of social class.

4. Preparation of school nurses should include more experiences that will enhance the understanding of the health needs of children from different social classes.

5. It is suggested that appropriate information from this study be made avallable to school nurses, school personnel, and parents in order that they better understand the relationship of social class to school health services.

Recommendations for Further Studies

1. Efforts should be made to determine whether or not the social class of the school nurse affects the way she functions in the delivery of health services.

2. Further studies dealing with varying population densities in cities and communities need to be carried out to determine if the size and location of the community affects the attitudes of parents toward school health services.

3. A study is needed to determine if ethnic groups 
within the same social class expect different school health services. 
BIBLIOGRAPHY

. 


\section{A. BOOKS}

Anderson, C. L. School Health Practice. St. Louis: C. V. Mosby Company, 1956 .

Backstrom, Charles H. and Gerald D. Hursh. Survey Research. Minneapolis: Northwestern University Press, 1963.

Barber, Bernard. Social Stratification - A Comparative Analysis of St ructure and Process. New York: Harcourt, Brace, and company, 1957.

Berger, Peter L. Invitation to Sociology: A Humanistic Perspective. New York: Doubleday, Inc., 1963.

Byrd, Oliver E. School Health Administration. Philadelphia: W. B. Saunders Company, 1964 .

Clarke, David H. and H. H. Clarke. Research Processes in Physical Education, Recreation, and Health Education. Englewood cliffs, New Jersey: Prentice Hall, Inc, 1970 .

Curti, Merle. The Social Ideas of American Educators. Paterson, New Jersey: Pagent Books, Inc., 1959.

Goerke, Lenor S. and Ernest L. Stebbins. Mustard's Introduction to Public Health. New York: Macmillan Company, 1968.

Good, Carter V. Introduction to Educational Research. New York: Appleton-Century-Crofts, Inc., 1959 .

Gorden, Raymond L. Interviewing-Strategy, Technique, and Tactics. Homewood, Illinols: Dorsey Press, 1969.

Gordon, Milton M. A System of Social Class Analysis. Madison, New Jersey: Drew University, 1951.

Havighurst, Robert J. Education in Metropolitan Areas. Boston: Allyn and Bacon, 1966 .

Hiller, E. T. Principals of Sociology. New York: Harper and Brothers, 1933 .

Hodges, Harold M. Soclal Stratification Class in America. Cambridge, Massachuset ts: Schenkman publishing Company, Inc., 1964. 
Hollingshead, August B. Elmtown's Youth. New York: John Wiley and Sons, Inc., 1956.

Kahl, Joseph. The American Class Structure. New York: Rinehart and Company, Inc., 1957.

Kerlinger, Fred. Foundations of Behavioral Research. New York: Holt, Rinehart and Winston, Inc., 1964.

Mayer, Kurt B. Class and Soclety. New York: Random House, 1955.

Miller, Delbert C. Handbook of Research Design and Social Measurement. New York: David McKay Company, Inc., 1970.

Mouly, George J. The Sclence of Educational Research. New York: American Book Company, 1963.

Reiss, Albert J., Jr. Occupation and Social Status. New York: Free Press, 1961.

Reissman, Leonard. Class in American Soclety. New York: Free Press, 1959.

Rinsland, Henery D. A Basic Vocabulary of Elementary School Chlldren. New Yorkt: MacMillan Company, 1945.

Roach, Jack L., Llewellyn Gross, and Orville R. Gursslin. Social Stratification in the United States. Englewood Cliffs, New Jersey: Prentice-Hall, Inc.; 1969.

Van Dalen, Deobold B. and William J. Meyer. Understandine Educational Research. New York: McGraw-Hill Book Company, 1966.

Warner, Lloyd $W$. and others. Social Class in America. New York: Harper and Row, 1950.

Warner, Lloyd W. and others. "Social Class in America," The Social Matrix of Physical Education. Englewood Cliffs, New Jersey: Prentice-Hall, Inc., 1968.

Weber, Max. "Class, Status, Party," Essays in Sociology. New York: Oxford University Press, 19646.

Williams, Robin M., Jr. American Society: A Sociological Interoretation. New York: Alfred A. Knopf, 1960.

Wysong, Jere A. and Robert L. Eichhorn. "Reaching the Tuberculosis Poor," Poverty in the Affluent Society. New York: Harper and Row, 1966. 


\section{B. JOURNALS}

Bryan, Doris S., and Thelma S. Cook. "Redirection of School Nursing Services in Culturally Deprived Neighborhoods," Journal of School Health, Vol. XXXIV, No. 4, April, 1969, pp. $247-248$.

Burney, Leroy E. "New Missions in Health Services: To Act or to React?" Journal of School Health, Vol. XL, No. I, January, 1970, p. 4 .

Campbell, Elizabeth P. "School Health Service-ProblemsSolutions-Ideas as Viewed by the Board of Education,"

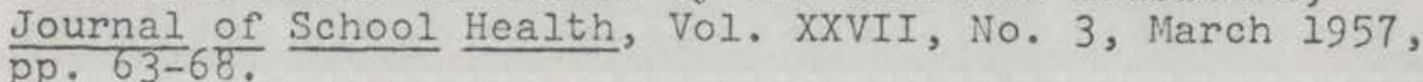

Cromwell, Gertrude E. "The Future of School Nursing,"

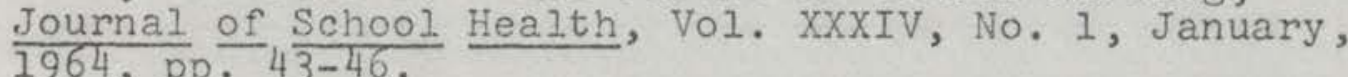

Dennison, Darwin. "Health Behavioral Differences Between Low and Middle Social Class Students," Journal of School Health, Vol. XXXIV, No. 10, December, 1969, pp. $\frac{19}{731-735 .}$

Florentine, Helen Goodale. "The Preparation and the Role of Nurses in School Health Programs," National League for Nursirig, 1962, pp. 9-11.

Frary, Ruth A. "School Health Services: Kindergarten Through College," Journal of School Health, Vol. XXXVIII, No. 4, Apri1, 1968, pp. 207-212.

Fricke, Irma B. "Recommended Policies and Practices for School Nursing," Journal of School Health, Vol. XXIV, No. 10, December, 1959, p. 30 .

Jenne, Frank H. "Variations in Nursing Service Characteristics and Teachers' Health Observation Practices," Journal of School Health, Vol. XL, No. 5, May, 1970, pp. $248-250$.

Kreidberg, Marshall and Homer B. C. Reed, Jr. "An Experimental Problem for the Delivery of Health Care Services to Public School Children," Journal of School Health, Vol. XXXIX, No. 4, April, $1969, \mathrm{pp}, 231-236$.

Means, Richard K. "Contributions of the White House Conference on Children and Youth to School Health Education," Journal

of School Health, Vol. XXX, No. 9, November, 1960, pp. 323-333. 
Nellson, Elizabeth A. "An Analytical Study of School Health Service Practices in the United States," Journal of School Health, Vol. XXX, No. 9, November, 1960, pp. 353-359.

Paige, Joseph C. "Health Programs for the Disadvantaged: Implications for School Health," Journal of School Health, Vol. XL, No. 3, March, 1970, pp. $\overline{123-126 . ~}$

Shannon, Iris R. "Nursing Service at the Mile Square Health Center of Presbyterian-St. Luke's Hospital, "American Journal of Public Health, Vol. 60, No. 9, September, 1970, p. 1731 .

Steinman, David. "Health in Rural Poverty: Some Lessons in Theory and from Experience," American Journal of Public Health, Vol. 60, No. 9, September, 1970, p. 1823.

Straus, R. "Soclological Determinants of Health Beliefs and Behavior," American Journal of Public Health, Vol. 51, No. 10, October, 1961 , pp. $1547-1549$.

Tower, Billie and Patricia Fay. "Can Contracted School Health Services Work?" Journal of School Health, Vol. XXXVIII, No. 6, June, 1968, pp. $33 \overline{9-34 I . ~}$

Wallace, Helen M. "Evaluation of School Health Services," Journal of School Health, Vol. XXXIII, No. 4, April, 1963,

Wallace, Helen M. "School Health Services," Journal of School Health, Vol. XXIX, No. 8, October, 1959, pp. 283-295.

\section{PUBLICATIONS OF LEARNED SOCIETIES AND OTHER ORGAINIZATIONS}

American Nurses' Association, Public Health Nurses Section, and School Nurses Branch, "Functions and Qualifications for School Nurses," July, 1960, pp. 1-3.

American Nurses' Association, "School Nursing," New York: American Nursing Association, 1966, p. 1.

Committee on School Health Service Statistics-School Health Section, "School Health Service Statistics," American

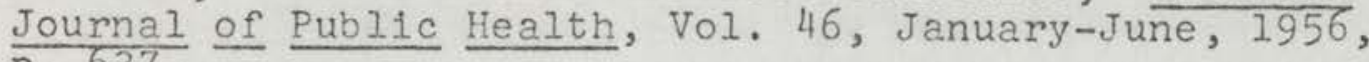


"Committee on Terminology in School Health Education," Journal of the American Association for Health, Physical Education, and Recreation, 22 No. 7, September, 1951 , p. 14.

A Joint Committee on Terminology, "Health Education Terminology," Journal of School Health, Vol. XXXIII, No. 3, March, 1963, p. 121.

National Committee on School Health Policies of the National Education Association and the American Medical Association, "Suggested School Health Policies," 1966, p. 12.

National Council for School Nurses of the School Health Division of the American Association for Health, Physical Education, and Recreation, "Solutions to Critical Health Needs," School Nursing Monograph No. 1, 1969, pp. 1-38. 
APPENDIX A 


\section{Questions About School Health Services}

Dear Parent:

We need your help in learning about school health services. Will you answer the following questions for us, please? All you need to do is look at four answers and write the number of the answer you want in the space at the beginning of the question.

$\begin{array}{ll}\text { Answers: } & \text { 1. Yes } \\ & \text { 2. Sometimes } \\ & \text { 3. No } \\ & \text { 4. Don't Know }\end{array}$

Example: 1 Do you feel your child's health is important? Because the answer is Yes a 1 is placed in the space at the beginning of the question.

All information from this survey will be used only by the investigator to help improve the school health services your child receives.

A. Should first aid at your child's school be done only by the school nurse?

B. Should the school nurse be the only adult to work in the school health room?

C. Should the school nurse help you make arrangements to get health treatment for your child if needed?

D. Should the school nurse talk to other people (custodian, bus driver, etc.) about the health needs of children such as clean bathrooms, and safety in the school and on the bus?

E. Should the school nurse teach classes about health?

F. Should the school nurse teach classes about sex education?

G. Should the school nurse teach classes about drug education?

H. Should the school nurse help with inspections of the bathrooms, playground, and cafeteria of the school? 
I. Should the school nurse make safety inspections of the gym, playground, and other school areas?

J. Should the school nurse be the only one to record health information on your child's health record?

$K$. Should the school nurse be the only one to see your child's health record?

L. Should the school nurse talk to you when your child needs shots (immunization)?

M. Should the school nurse share information about your child's health with the

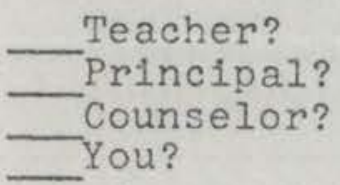

N. Should the school nurse test your child for Vision?

Hearing? T.B.?

0. Should the school nurse have a health talk (conference) with your child at least once a year?

P. Would a talk with the school nurse about your child's health be of value to you?

Q. Does the school nurse spend enough time at your child's school?

In the next three questions please check $(v)$ the answers you want:

R. Have you ever met the school nurse? If yes please check where:

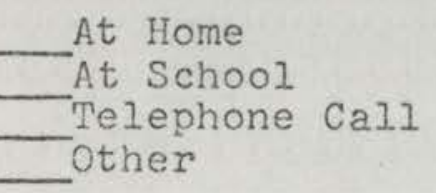


S. Who calls you from school when your child is sick or injured? Please check:

\section{School Nurse}

Teacher

Principal

Counselor

Secretary

Aide

T. If the school nurse had to talk to you about your child's health which way would you like best? Please check:

In Your Home

By Telephone

A Note Sent Home by Your Child. At the School

In your family what kind of work do the father and mother do?

Father's job

Mother's job

Are there other health services you would like the school nurse to provide for your child? Please Explain:

Comments: Please feel free to make any comments you wish about school health services in your child's school.

Please have your child return this survey to his teacher tomorrow.

Thank You Very Much 
Preguntas De Servicios Perteniciendo a La Salud De Su Hijo o Hija en la Escuela

\section{Padres:}

Necesitamos su ayuda para aprender mas de los servicios de la buena salud de sus hijos en la escuela. ¿Por favor contesten las siguentes preguntas? Primero miren las cuatro respuestas y despues pongan el numero de la respuesta que usted quiere en el espacio al princepio de la pregunta.

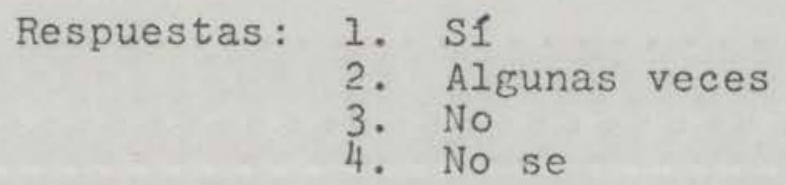

Ejemplo: ¿Piensa usted que la salud de su hijo o hija es importante? Porque la Respuesta es Sí, el numero 1 va puesta en el espacio al principio de la pregunta.

Toda la informacion que se junte con estas preguntas sera usada por este investigador para ayudar mejorar los servicios de la buena salud que recivé su hijo o hija en la escuela.

A. ¿Seria bien que la enfermera de la escuela seya la unica persona para dar ayuda perteniciendo a la buena. salud de su hijo o hija en la escuela?

B. ¿Sera bueno que la unica persona que trabaje en la ofecina de la enfermera seya la enfermera?

C. iSera bien que la enfermera de la escuela les ayude acer areglos para conceguir tratamintos perteniciendo a la buena salud de su hijo o hija si lo necesitan?

D. iSera bueno que la enfermera de la escuela hable con otra gente (el que Liempa, manijador de comuneta, etc.) sobre las necesidades perteniciendo a la buena salud de su hijo o hija, cosas como lavatorios limpios, y cuidado en la escuela, en el autobus?

E. ¿Sera bien que la enfermera de la escuela de clases perteniciendo a la buena salud de su hijo o hija?

F. ¿Sera bien que la enfermera de la escuela de clases sexual? 
G. ¿Sera bien que la enfermera de la escuela de clases perteniciendo al mejor modo de usar drugas?

H. ¿Sera bien que la enfermera de la escuela ayude en inspeciones de lavatorios, lugares donde juegan muchachos y otros lugares en la escuela?

I. ¿Sera bien que la enfermera de la escuela haga inspeciones en gimnasio, lugares donde juegan muchachos, y otros lugares en la escuela?

J. ¿Sera bien que la enfermera de la escuela sera la unica persona que puede tener informacion perteniciendo de la salud de su hijo o hija?

K. ¿Sera bien que la enfermera de la escuela seya la unica persona que puede ver la informacion perteniciendo a la salud de su hijo o hija?

L. ¿Sera bien que la enfermera de la escuela les hable cuando su hijo o hija necesita una injection?

M. ¿Sera bien que la enfermera de la escuela reparte informacion a cerea de la salud de su hijo o hija con

el maestro?

el princepal? el consejero? usted?

N. iSera bien que la enfermera de la escuela excamine su hijo o hija de los

ojos?

oidos?

T.B.?

0. ¿Sera bien que la enfermera de la escuela les hable sobre la salud de sue hijo o hija a lo menos una vez al año?

P. ¿Fuera ayuda o tuviera valor para usteds si la enfermera de la escuela les hablaba sobre la salud de su hijo o hija?

Q. iSe queda suficiente tiempo la enfermera en la escuela de su hijo o hija? 
R. ¿Conocen ustedes a la enfermera de la escuela? Sí la contesta es Si, marquen donde la conocieron?

la casa
la escuela
por teleforo
otro modo

S. ¿Quién llama de la escuela cuando su hijo o hija estan enfermos o lastimados? Marquen por favor:

la enfermera de la escuela

el maestro

el principal.

el consejero

la secretaria

las ayudanta

T. ¿Si la enfermera de la escuela tuviera que hablar con ustedes sobre la salud de su hijo o hija a cual modo les gustaria mas? Marquen por favor: en la casa por telefone una nota mandada para la casa con su hijo o hija en la escuela

¿En su familia que clas de trabajo hace su papa y su mama?

Trabajo del padre

Trabajo de la madre

Hay otros servicios perteniciendo a la salud de su hijo o hija en donde pudiera ayudar la nodrisa de las escuela? Si hay, escribanlos por favor:

PALABRAS: Ahora si quisieran escriban lo que quieran sobre los servicios ofredcidos para la salud de su hijo o hija en la escuela?

Me hacen el facor de volver esta forma con su hijo o hija al maestro mañana. 
APPENDIX B 
Occupations by Major Occupation Group

Professional, technical, and kindred workers

Accountants and auditors Actors and actresses

Airplane pilots and navigators

Architects

Artists and art teachers

Athletes

Authors

Chemists

Chiropractors

Clergymen

College presidents, professors, and instructors

Dancers and dancing teachers

Dentists

Designers

Dieticians and nutritionists

Draftsmen

78

60

79

90

67

52

76

79

75

52

Editors and reporters

Engineers, technical

Aeronautical

85

Chemical

Civil

Electrical

Industrial

Mechanical

Metallurgical, and metallurgists

87

90

84

84

86

82

Mining

Not elsewhere classified

Entertainers

Farm-and home-management advisors

Foresters and conservationists

Funeral directors and embalmers

Lawyers and judges

Librarians

Musicians and music teachers

Natural scientists

Nurses, professional.

Nurses, student professional Optometrists 
Occupations by Major Occupation Group

\begin{tabular}{cc} 
Socio- & Population \\
economic & Decile \\
Index & Scale \\
\hline
\end{tabular}

Osteopaths

Personnel and labor-relations workers

Pharmacists

Photographers

Physicians and surgeons

Radio operators

Recreation and group workers

Religious workers

Social and welfare workers, except group

Social scientists

Sports instructors and officials Surveyors

Teachers

Technicians, medical and dental

96

10

84

82

50

92

69

67

56

10

10

9

10

64

81

64

48

72

48

Technicians, testing

Technicians

Therapists and healers

Veterinarians

Professional, technical

and kindred workers

53

62

58

78

65

9

10

Farmers and farm managers

Farmers (owners and tenants)

Farm managers

Managers, officials, and proprietors, exc. farm

Buyers and department heads, store

Buyers and shippers, farm products

Conductors, railroad

Credit men

Floormen and floor managers, store

Inspectors, public administration

Federal public administration and postal service

State public administration

Local public administration

Managers and superintendents,

building 
Occupations by Major

Socio-

Occupation Group

economic

Population

Index

Declile

Scale

Officers, pilots, pursers, and engineers, ship

Officials and administrators

public administration

Federal public administration

and postal service

State public administration

Local public administration

officials, lodge, society,

union, etc.

Postmasters

Purchasing agents and buyers

Managers, officials, and

proprietors-salaried

Construction

Manufacturing

Transportation

Telecommunications, and utilities and sanitary services

54

66

84

10

66

54

10

58

60

77

71

Wholesale trade

Retall trade

Food-and dairy-products

stores, and milk retailing

General merchandise and fiveand ten-cent stores

Apparel and accessories stores

Furniture, home furnishings, and equipment stores

Motor vehicles and accessories retaling

Gasoline service stations

Eating and drinking places

Hardware, farm implement,

and building material, retail

other retail trade

Banking and other finance

76

10

70

10

56

50

8

68

69

10

68

10

65

31

39

64

59

85

Insurance and real estate

Business services

Automobile repair services and garages

Miscellaneous repair services

Personal services

All other industries (incl. not reported)

84

80

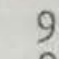

50 
Occupations by Major

Sociooccupation Group

economic Index

Population

Decile

Scale

Managers, officials, and

proprietors--self-employed

48

Construction

Manufacturing

Transportation

Telecommunications and utilities and sanitary services

Wholesale trade

Retall trade

Food-and dairy-products stores, and milk retailing

General merchandise and fiveand-ten-cent stores

Apparel and accessories stores

Furniture, home furnishings, and equipment stores

Motor vehicles and accessories retalling

Gasoline service stations

Eating and drinking places

Hardware, farm implement, and building material, retail

other retail trade

Banking and other finance

Insurance and real estate

Business services

Automobile repair services and garages

Miscellaneous repair services

Personal services

All other industries (incl, not reported)

51

61

43

44

59

43

65

Clerical and kindred workers

Agents

Attendants and assistants, library

Attendants, physician's and

dentist's office

44

Baggagemen, transportation

Bank tellers

Bookkeepers

Cashiers

Collectors, bill and account

Dispatchers and starters, vehicle

39

40 
Occupations by Major Occupation Group

Socioeconomic Index
Population

Decile

Scale

Express messengers and rallway mail clerks

Mail-carriers

Messengers and office boys

office-machine operators

Shipping and receiving clerks

Stenographers, typists, and

secretaries

Telegraph messengers

Telegraph operators

Telephone operators

Ticket, station, and express agents

22

Clerical and kindred workers

\section{Sales Workers}

Advertising agents and salesmen 66 Auctioneers

Demonstrators

Hucksters and peddlers

Insurance agents and brokers

Newsboys

estate agents and brokers

Salesmen and sales clerks

47

Manufacturing

Wholesale trade

61

Retail trade

Other industries (incl. not reported) 50

Craftsmen, foremen, and kindred workers

Bakers

Blacksmiths

Bollermakers

Bookbinders

Brickmasons, stonemasons, and tile-setters

Cabinetmakers

Carpenters

Cement and concrete finishers

Compositors and typesetters

Cranemen, derrickmen, and hoistmen 
Occupations by Major Occupation Group

\begin{tabular}{cc} 
Soc1o- & Population \\
economic & Decile \\
Index & Scale \\
\hline
\end{tabular}

Decorators and window-dressers

Electricians

Electrotypers and stereotypers

Engravers, except photoengravers

Excavating, grading, and road-machinery operators 24

Foremen

Construction

Manufacturing

Metal industries

Machinery, including electrical

Transportation equipment

Other durable goods

Textiles, textile products, and apparel

Other nondurable goods (incl. not specified $\mathrm{mfg}$.)

Railroads and railway express service

Transportation, except railroad

Telecommunications, and utilities and sanitary services

Other industries (incl. not reported)

Forgemen and hammermen

Furriers

Glaziers

Heat treaters, annealers, and temperers

Inspectors, scalers, and graders,

$10 \mathrm{~g}$ and lumber

Inspectors

Construction

Railroads and railway express service

Transport, exc. r.r., communication and other public util.

other industries (incl. not reported)

Jewelers, watchmakers, goldsmiths, and silversmiths

Job-setters, metal

Linemen and servicemen, telegraph, telephone, and power

Locomotive engineers

40

44

55

24
49

40

53

54

60

66

41

39

53

36

45

56

44

23

39

26

22

23

41

46

41

45

38

36

28

49

58
8

8

9

8

6

8

8

9

9

7
8

9

8

6

7

6

6

8

8

8

8

7

7

8

9 
Occupations by Major Occupation Group

\begin{tabular}{cc} 
Socio- & Population \\
economic & Decile \\
Index & Scale \\
\hline
\end{tabular}

Locomotive firemen

Loom fixers

45

8

Machinists

Mechanics and repairmen

Airplane

Automobile

Office machine

Radio and television

Railroad and car shop

Not elsewhere classified

10

33

25

48

19

36

36

23

27

Millers, grain, flour, feed, etc. 19

Millwrights

31

Molders, metal

Motion-picture projectionists

12

43

Opticians, and lens grinders and polishers

Painters, construction and maintenance

Paperhangers

Pattern and model-makers, except paper

Photoengravers and lithographers

Piano and organ tuners and repalrmen

Plasterers

Plumbers and steam-fitters

Pressmen and plate printers, printing

Rollers and roll hands, metal

Roofers and slaters

Shoemakers and repairers, except factory

Stationary engineers

Stone-cutters and stone-carvers

Structural-metal workers

Tallors and tailoresses

Tinsmiths, coppersmiths, and sheet-metal workers

Toolmakers, and die-makers and setters

Upholsterers

Craftsmen and kindred workers

Members of the armed forces 
Occupations by Major

Soc10Occupation Group

Operatives and kindred workers

Apprentices

Auto mechanics

Bricklayers and masons

Carpenters

Electricians

Machinists and toolmakers

Mechanics, except auto

Plumbers and pipe-fitters

Building trades

Metalworking trades

Printing trades

other specified trades

Trade not specified

Asbestos and insulation workers

Attendants, auto service and parking

Blasters and powdermen

Boatmen, canalmen, and lock-keepers

Brakemen, railroad

Bus-drivers

Chainmen, rodmen, and axmen, surveying

Conductors, bus and street rallway

Deliverymen and routemen

Dressmakers and seamstresses, except factory

Dyers

Filers, grinders, and polishers, metal

Fruit, nut and vegetable graders and packers, exc. factory

Furnacemen, smeltermen, and pourers Heaters, metal

Laundry and dry-cleaning operatives

Meat-cutters, except slaughter and packing house

Milliners

Mine operatives and laborers

Coal mining

Crude petroleum and natural

gas extraction

Mining and quarrying, except fuel 
Occupations by Major Occupation Group

Socio-

economic

Index
Population

Decile

Scale

Motormen, mine, factory, logging camp, etc.

Motormen, street, subway, and elevated railway

Ollers and greasers, except auto

Painters, except construction and maintenance

Photographic-process workers

Power-station operators

Sailors and deck hands

Sawyers

Spinners, textile

Stationary firemen

Switchmen, railroad

Taxicab-drivers and chauffeurs

Truck and tractor drivers

Weavers, textile

Welders and flame-cutters

Operatives and kindred workers

$\begin{array}{rr}3 & 1 \\ 34 & 7 \\ 15 & 4 \\ 18 & 5 \\ 42 & 8 \\ 50 & 9 \\ 16 & 4 \\ 5 & 1 \\ 5 & 1 \\ 17 & 4 \\ 44 & 8 \\ 10 & 2 \\ 15 & 4 \\ 6 & 1 \\ 24 & 6\end{array}$

18

4

Manufacturing

Durable goods

Sawmilis, planing mills, and misc. wood products

Sawmills, planing mills and mill work

Miscellaneous wood products

Furniture and fixtures

Stone, clay, and glass products

Glass and glass products

Cement, and concrete, gypsum; and plaster products

Structural clay products

Pottery and related products

Misc. nonmetallic mineral and stone products

Metal industries

Primary metal industries

Blast furnaces, steel works, and rolling mills

other primary iron and steel industries

Primary nonferrous industries 
Occupations by Major Occupation Group

Socio-
economic
Index

Population Decile Scale

Fabricated metal ind. (incl. not spec. metal)

Fabricated steel products Fabricated nonferrous metal products Not specified metal industries

Machinery, except electrical

Agricultural machinery and tractors

office and store machines and devices

Miscellaneous machinery

Electrical machinery, equipment, and supplies

Transportation equipment

Motor vehicles and motor vehicle equipment

Aircraft and parts

Ship and boat building and repairing

Railroad and misc. transportation equipment

Professional and photographic equipment and watches

Professional equipment and supplies

Photographic equipment and supplies

Watches, clocks, and clockwork-operated devices

Miscellaneous manufacturing industries

Nondurable goods

Food and kindred products

Meat products

Dairy products

Canning and preserving fruits, vegetables, and sea foods

Grain-mill products

Bakery products

Confectionery and related products

Beverage industries

Misc. food preparations and kindred products

16

16

15

14

22

21

31

22

26

23

21

34

16

23

29

23

40

28

16

16

16

22

9

14
15

12

19

11
4

5

6

6

4

4

3

6

6

5

4

6

6

6

8

6

4

4

4

6

2

4

2
5

2 


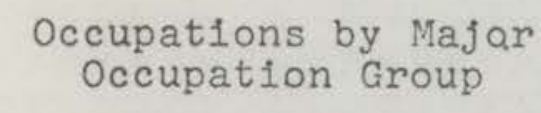
Socio-
economic
Index

Population
Decile
Scale

Not specified food industries

Tobacco manufactures

Textile mill products

Knitting milis

Dyeing and finishing textiles, exc. knit goods

Carpets, rugs, and other floor coverings

Yarn, thread, and fabric mills

Miscellaneous textile mill products

Apparel and other fabricated

textile products

Apparel and accessories

19

2

21

5
1
1
5

8

2

14

2

4

10

2

Miscellaneous fabricated textile products

Paper and allied products

21

22

6

17

19

Pulp, paper and paperboard mills 19

Paperboard containers and boxes 17

Miscellaneous paper and pulp products

19

5

Printing, publishing, and allied industries

Chemicals and allied products

Synthetic fibers

Drugs and medicines

Paints, varnishes, and related products

Miscellaneous chemicals and allied products

Petroleum and coal products

Petroleum refining:

Miscellaneous petroleum and coal products

Rubber products

Leather and leather products

Leather: tanned, curried, and finished

31

20

9

26

15

6

5
2
6

23

51

56

4

5

5

Footwear, except rubber

14

22

16

6

Leather products, except footwear 14

10

9

Not specified manufacturing

industries

Nonmanufacturing industries (incl.

not reported)

16

Construction

18

18

4

6

9

9

3
6
4

2

2

3

4

4

5 
Occupations by Major Occupation Group

\begin{tabular}{cc} 
Socio- & Population \\
economic & Decile \\
Index & Scale \\
\hline
\end{tabular}

Railroads and railway express service

Transportation, except railroad

Telecommunications, and utilities and sanitary services

Wholesale and retall trade

Business and repair services

Personal services

Public administration

All other industries (incl. not reported)

Private-household workers

Housekeepers, private household

Living in

Living out

Laundresses, private household

10

21

12

Living in

Living out

Private-household workers

Living in

Living out

$\begin{array}{rr}12 & 2 \\ - & \\ 12 & 2 \\ 7 & 2 \\ 12 & 2 \\ 6 & \end{array}$

Service workers, except private household

Attendants, hospital and other institution

Attendants, professional and personal service

Attendants, recreation and amusement

Barbers, beauticians, and

Bartenders

Boarding-and lodging-housekeepers

Bootblacks

Charwomen and cleaners

Cooks, except private household

Counter and fountain workers

Elevator operators

10

Firemen, fire protection

Guards, watchmen, and doorkeepers

37

18 
Occupations by Major

occupation Group

Socio-

economic

Population

Decile

Index

Scale

Housekeepers and stewards, except private household

Janitors and sextons

Marshals and constables

Midwives

Policemen and detectives

Government

Private

Porters

Practical nurses

Sheriffs and bailiffs

Ushers, recreation and amusement

Waiters and waitresses

Watchmen (crossing) and bridgetenders

Service workers, except private household

Farm laborers and foremen

Farm foremen

Farm laborers, wage workers

Farm laborers, unpaid family workers

Farm-service laborers, selfemployed

Laborers, except farn and mine

Fishermen and oystermen

Garage laborers, and car-washers and greasers

Gardeners, except farm, and groundkeepers

Longshoremen and stevedores

Lumbermen, raftsmen, and wood-choppers Teamsters

\section{Laborers}

Manufacturing

Durable goods

Sawmilis, planing mills, and

misc. wood products

Sawmills, planing mills, and mill work

Miscellaneous wood products Furniture and fixtures

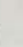


Occupations by Major Occupation Group
Socio-
economic

Index
Population

Decile

Scale

Stone, clay, and glass products Glass and glass products

Cement; and concrete, gypsum, and plaster prod.

Structural clay products

Pottery and related products

Misc. nonmetallic mineral and stone products

Metal industries

Primary metal industries

Blast furnances, steel works, and rolling mills

Other primary iron and steel industries

Primary nonferrous industries

Fabricated metal ind. (incl. not spec. metal)

Fabricated steel products

Fabricated nonferrous metal products

Not specified metal industries

Machinery, except electrical

Agricultural machinery and tractors

Office and store machines and devices

Miscellaneous machinery

Electrical machinery, equipment, and supplies

Transportation equipment

Motor vehicles and motor

vehicle equipment

Aircraft and parts

Ship and boat building and repairing

Railroad and misc. transportation equipment

7
14

2
3

5
5
7

$\frac{1}{1}$

5
7
7

1
2
2

9

2

4

6

1

1

7
7

2
2

10

2

9

2

11

2

14

3

17

10

4

14

11

3

13

15

2
4

2

1

8

2

Professional and photographic

equipment, and watches

Professional equipment and supplies

Photographic equipment and supplies 
Occupations by Major

Occupation Group

Socio-

economic

Population

Index

Decile

Scale

Watches, clocks, and

clockwork-operated devices

Miscellaneous manufacturing

industries

Nondurable goods

Food and kindred products

Meat products

Dairy products

Canning and preserving fruits, vegetables, and sea foods

Grain-mill products

Bakery products

Confectionery and related products

Beverage industries

Misc. food preparations and kindred products

Not specified food industries

Tobacco manufactures

Textile mill products

Knitting milis

Dyeing and finishing textiles, exc. knit goods

Carpets, rugs and other floor coverings

Yarn, thread, and fabric mills

Miscellaneous textile-mill products

Apparel and other fabricated

textile products

Apparel and accessories

Miscellaneous fabricated textile products

Paper and allied products

Pulp, paper, and paperboard milis

Paperboard containers and boxes

Miscellaneous paper and pulp products

Printing, publishing, and allied industries

Chemicals and allied products

Synthetic fibers

Drugs and medicines

61 
Occupations by Major

Occupation Group

Socio-

economic

Index
Population Decile

Scale

Paints, varnishes and related products

Miscellaneous chemicals and allied products

Petroleum and coal products

Petroleum refining

Miscellaneous petroleum and coal products

Rubber products

Leather and leather products

Leather: tanned, curried, and finished

Footwear, except rubber

Leather products, except

footwear

Not specified manufacturing

industries

Nonmanufacturing industries (incl. not reported)

Construction

Railroads and rallway express service

Transportation, except railroad

Telecommunications, and utilities and sanitary services

Wholesale and retall trade

Business and repair services

Personal services

Public administration

All other industries (Incl, not reported)

occupation not reported

$\begin{array}{rr}8 & 2 \\ 22 & 6 \\ 26 & 6\end{array}$

$\begin{array}{rr}3 & 1 \\ 12 & 2 \\ 6 & 1\end{array}$

$\begin{array}{rr}2 & 1 \\ 10 & 2\end{array}$

122

82

$\begin{array}{ll}7 & 2 \\ 7 & 2\end{array}$

3

$\begin{array}{rr}6 & 1 \\ 12 & 2 \\ 9 & 2 \\ 5 & 1 \\ 7 & 2\end{array}$

$\begin{array}{rr}6 & 1 \\ 19 & 5\end{array}$ 
APPENDIX C 
TABLE 1

THE NUMBER AND PERCENTAGE OF QUESTIONNAIRES

RETURNED BY EACH SOCIAL CLASS

\begin{tabular}{lcccc}
\hline \hline & $\begin{array}{c}\text { Number of } \\
\text { Students }\end{array}$ & $\begin{array}{c}\text { Families } \\
\text { Receiving } \\
\text { Questionnaires }\end{array}$ & $\begin{array}{c}\text { Families } \\
\text { Returning } \\
\text { Questionnaires }\end{array}$ & $\begin{array}{c}\% \text { of } \\
\text { Returns }\end{array}$ \\
\hline Pajarito & 687 & 375 & 307 & 82 \\
Coronado & 631 & 281 & 258 & 92 \\
Duranes & 588 & 254 & 205 & 81 \\
Inez & 521 & 300 & 253 & 84 \\
Monte Vista & 472 & 350 & 301 & 87 \\
Carlos Rey & 642 & 400 & 389 & 97 \\
Chelwood & 460 & 460 & 313 & 68 \\
Acoma & 240 & 240 & 216 & 90 \\
Comanche & 375 & 375 & 291 & 78 \\
Total & 5,370 & 3,035 & 2,533 & $83^{*}$ \\
\hline \hline
\end{tabular}

*Total percentage of returns 


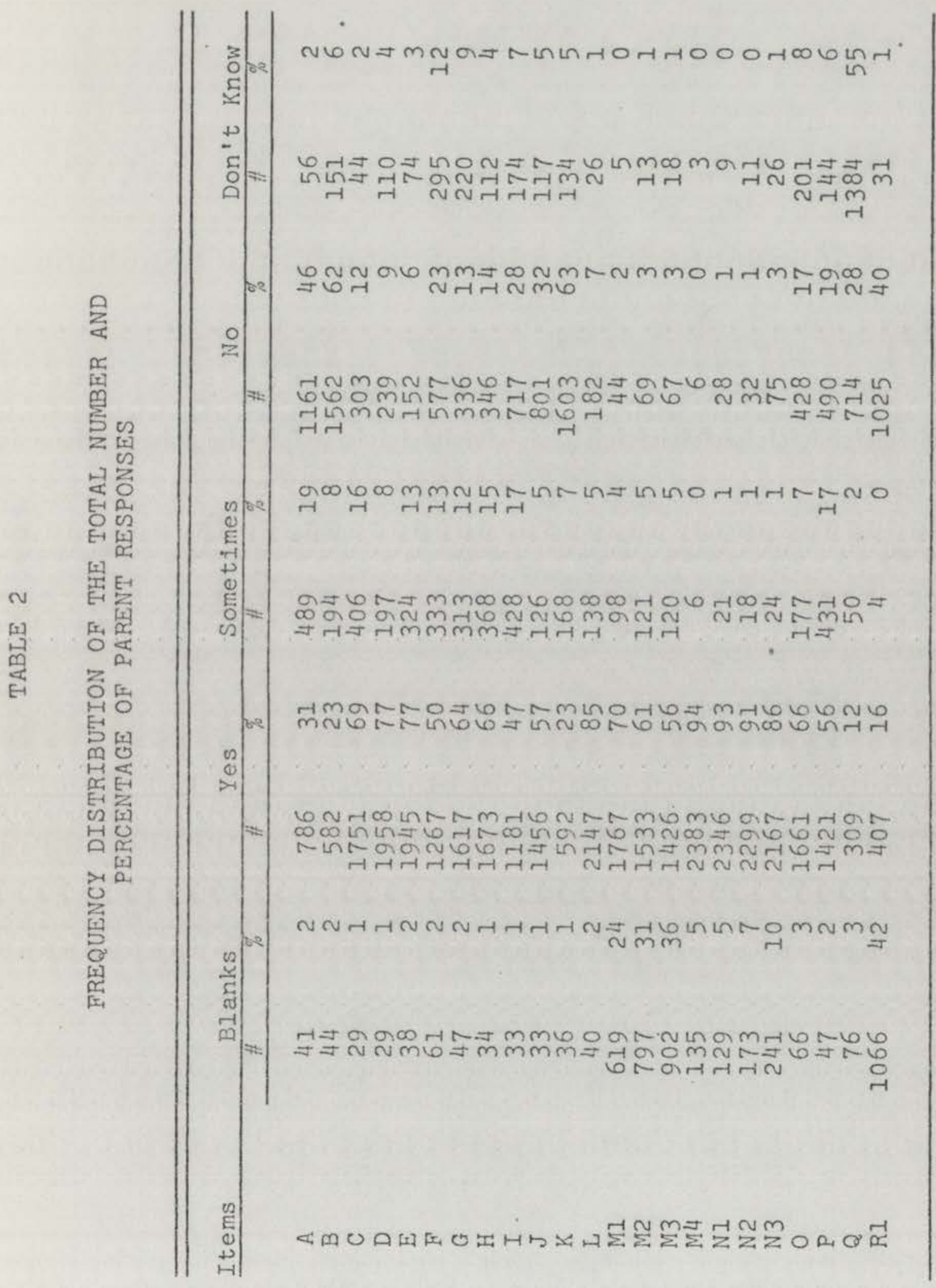




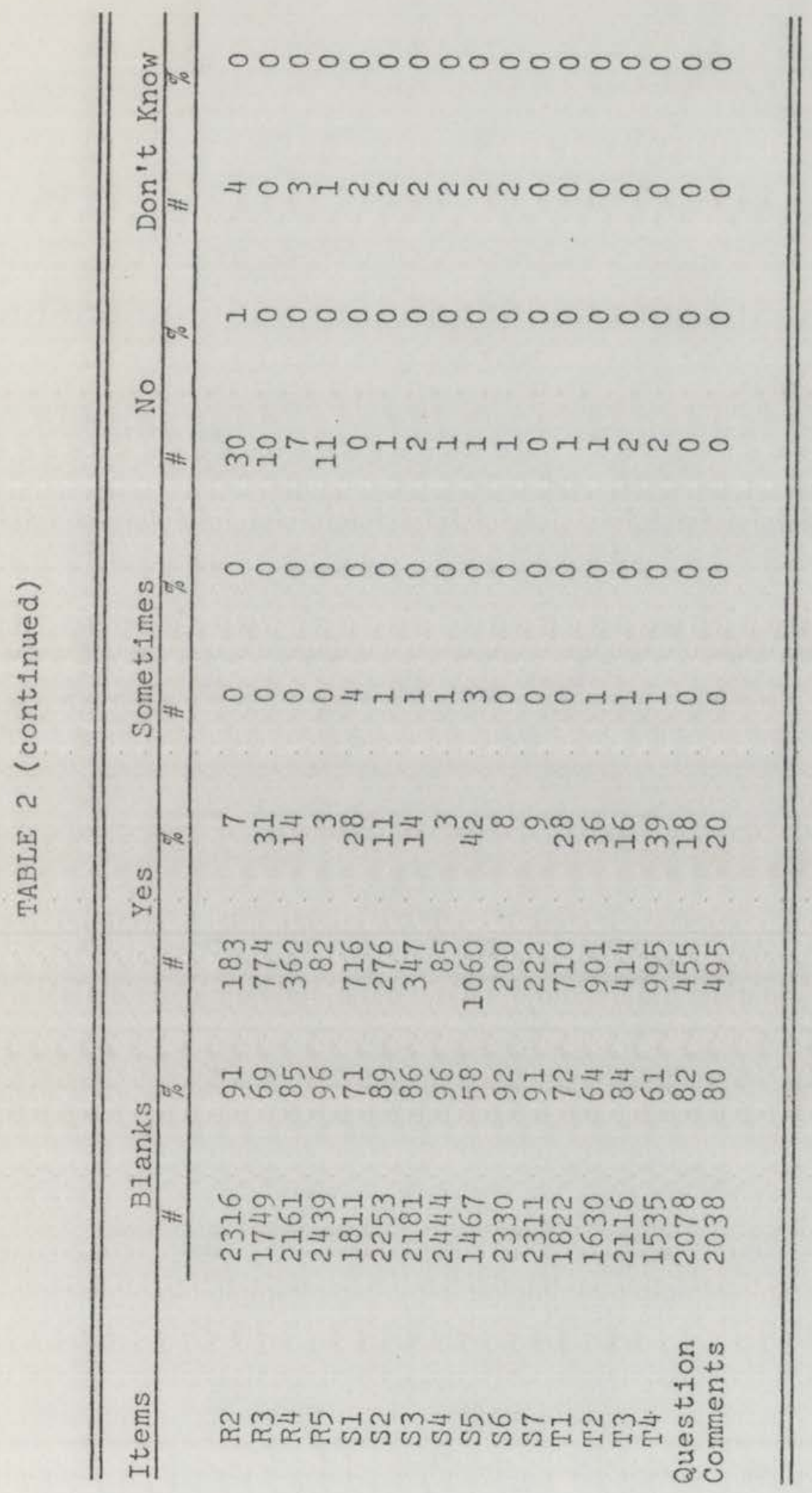


TABLE 4

PARENT RESPONSES TO QUESTIONNAIRE

\section{Pajarito School}

Items

Responses

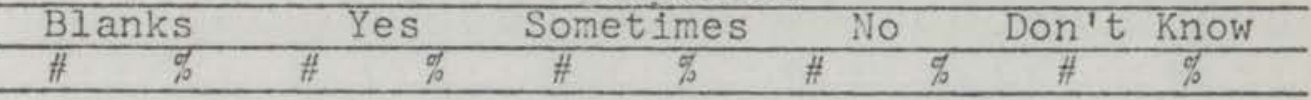

A

$\begin{array}{lllllllllll}7 & 2 & 88 & 29 & 70 & 23 & 131 & 43 & 11 & 4\end{array}$

B

C

D

E

F

G

$\mathrm{H}$

I

$\mathrm{J}$

L

MI

M2

M3

M4

N1

10

7

8

372

23

25

$\begin{array}{ll}8 & 177\end{array}$

14

20

$74 \quad 24$

826

$\begin{array}{lll}9 & 3 & 249 \\ 2 & 4 & 134\end{array}$

$81 \quad 28$

9

12

$\begin{array}{lll}9 & 3 & 221\end{array}$

$44 \quad 25$

$8 \quad 97$

$72 \quad 22$

732

$41 \quad 13$

45

51

114139

59

15

8374

2428

7. $\quad 2.263$

86

20

$74 \quad 24$

210

$\begin{array}{ll}68 & 17\end{array}$

$98 \quad 32$

172

$56 \quad 19$

$120 \quad 39$

144

$47 \quad 19$

17

48
86

582

$9 \quad 170$

7. 16

$\begin{array}{ll}15 & 5 \\ 19 & 6\end{array}$

289

$94 \quad 1$

66

N2

N3



279

91

614

$\begin{array}{ll}6 & 17\end{array}$

$31 \quad 10$

269

88

134

259

84

212

69

197

64

12

41

13

$\begin{array}{ll}0 & 2 \\ 1 & 4\end{array}$

Q

RI

145

47

68

22

15

3

$287 \quad 93$

19

6

24

$\frac{1}{8}$

53

17
1
0

58

23

10

823

R2

169

55

138

615

32

39

$10 \quad 23$

$\mathrm{R} 4$

$\begin{array}{ll}256 & 83 \\ 302 & 98\end{array}$

$51 \quad 17$

170

96

31.

28793

20

26988

37

7

$301 \quad 98$

62

S4

133

$43 \quad 173$

56

296

96

11

56

4

other

TI

T2

273
213

$89 \quad 34$

110

310

$\begin{array}{lll}211 & 69 & 96\end{array}$

31

T3

261

85

96
46

15

163

53144

47

Questions

Comments 255

85

47

15

52

17 
TABLE 4 (continued)

\section{Coronado School}

Items Responses

\begin{tabular}{cccccc} 
Blanks & Yes & Sometimes & No & Don't Know \\
\hline$\#$ & $\%$ & $\#$ & $\%$ & $\#$ & $\%$
\end{tabular}

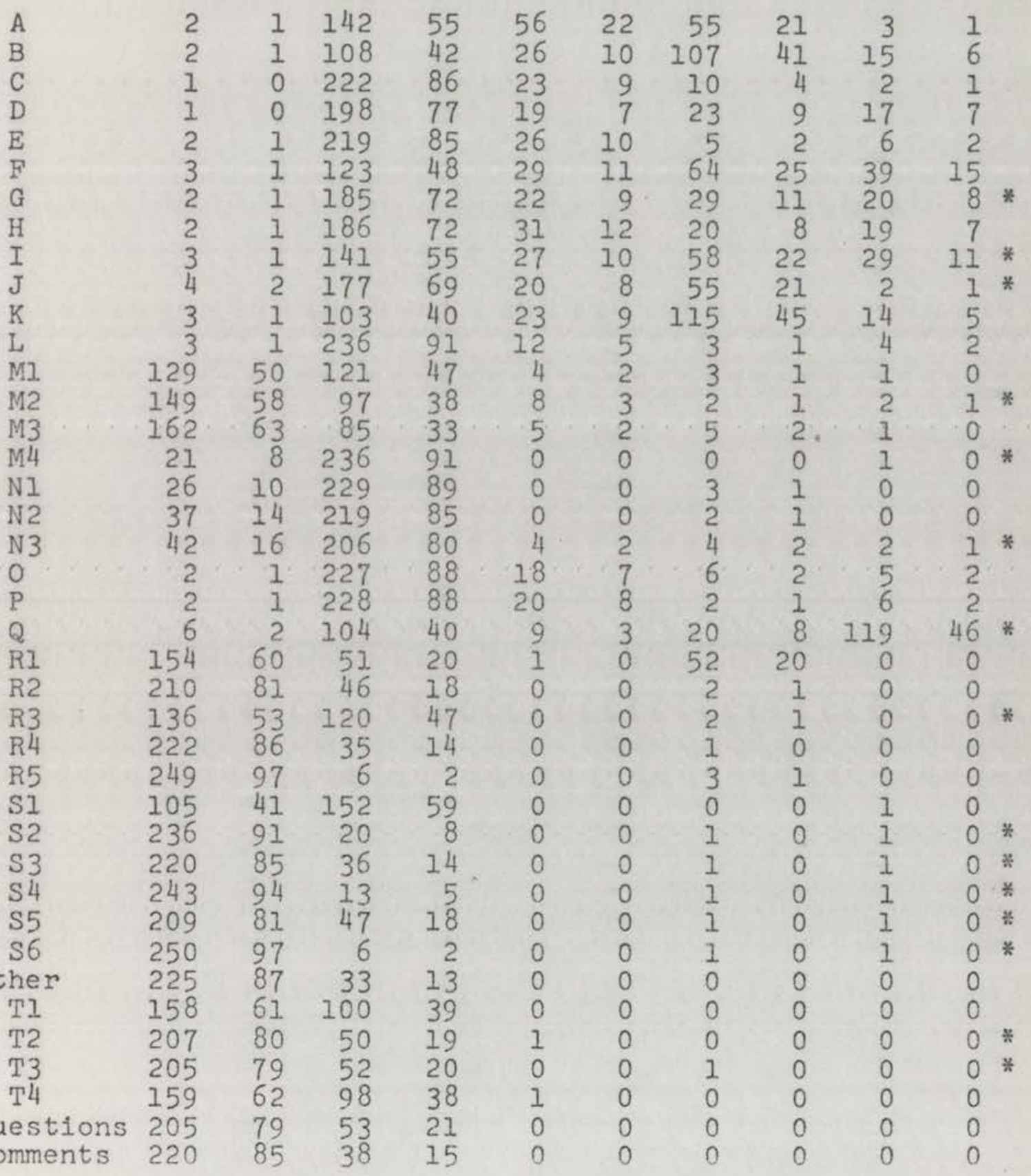


TABLE 4 (continued)

\section{Duranes School}

Items Responses

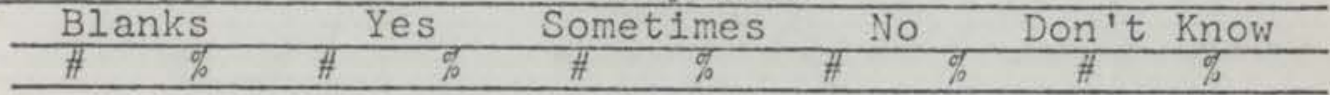

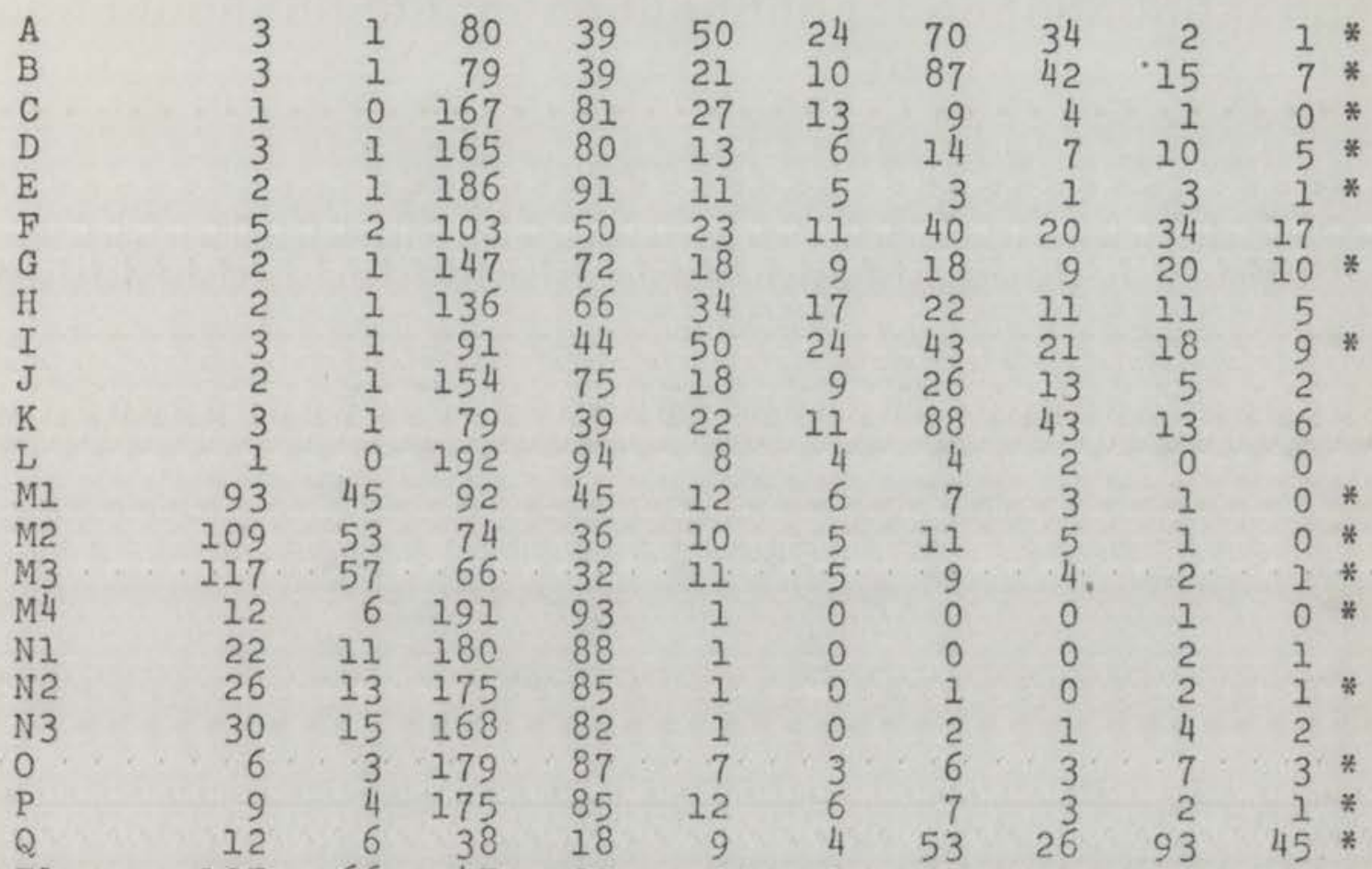

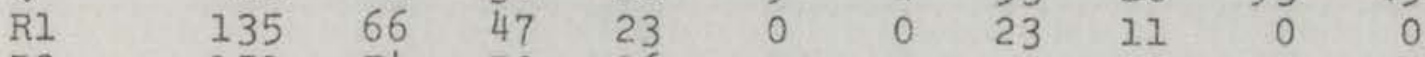

$\begin{array}{lllllllllll}R 2 & 151 & 74 & 53 & 26 & 0 & 0 & 1 & 0 & 0 & 0\end{array}$

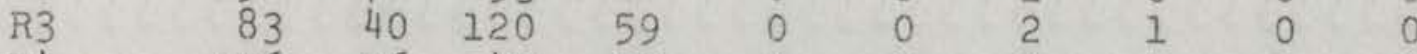

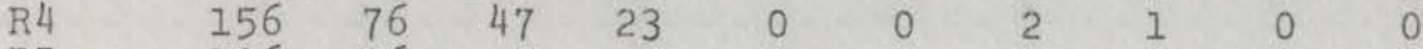

$\begin{array}{lllllllllll}\text { R5 } & 196 & 96 & 7 & 3 & 0 & 0 & 2 & 1 & 0 & 0\end{array}$

$\begin{array}{lllllllllll}\text { S1 } & 78 & 38 & 127 & 62 & 0 & 0 & 0 & 0 & 0 & 0\end{array}$

$\begin{array}{lllllllllll}\text { S2 } & 189 & 92 & 16 & 8 & 0 & 0 & 0 & 0 & 0 & 0\end{array}$

$\begin{array}{lllllllllll}\text { S3 } & 182 & 89 & 23 & 11 & 0 & 0 & 0 & 0 & 0 & 0\end{array}$

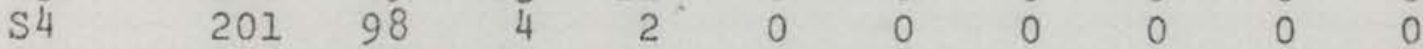

$\begin{array}{lllllllllll}55 & 136 & 66 & 69 & 34 & 0 & 0 & 0 & 0 & 0 & 0\end{array}$

$\begin{array}{lllllllllll}56 & 200 & 98 & 5 & 2 & 0 & 0 & 0 & 0 & 0 & 0\end{array}$

$\begin{array}{lllllllllll}\text { Other } & 192 & 94 & 13 & 6 & 0 & 0 & 0 & 0 & 0 & 0\end{array}$

$\begin{array}{lllllllllll}T 1 & 117 & 57 & 88 & 43 & 0 & 0 & 0 & 0 & 0 & 0\end{array}$

$\begin{array}{lllllllllll}\mathrm{T} 2 & 145 & 71 & 60 & 29 & 0 & 0 & 0 & 0 & 0 & 0\end{array}$

$\begin{array}{lllllllllll}T 3 & 172 & 84 & 32 & 16 & 0 & 0 & 0 & 0 & 0 & 0\end{array}$

$\begin{array}{lllllllllll}\mathrm{T} 4 & 131 & 64 & 73 & 36 & 0 & 0 & 1 & 0 & 0 & 0\end{array}$

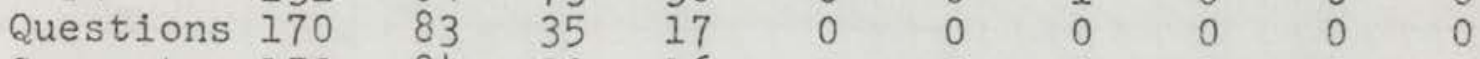

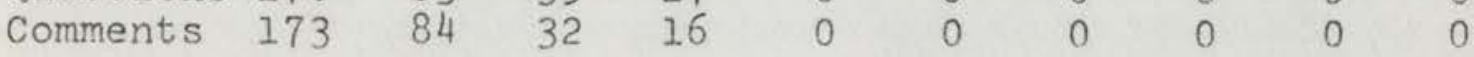


TABLE 4 (continued)

Inez School

Items

Responses

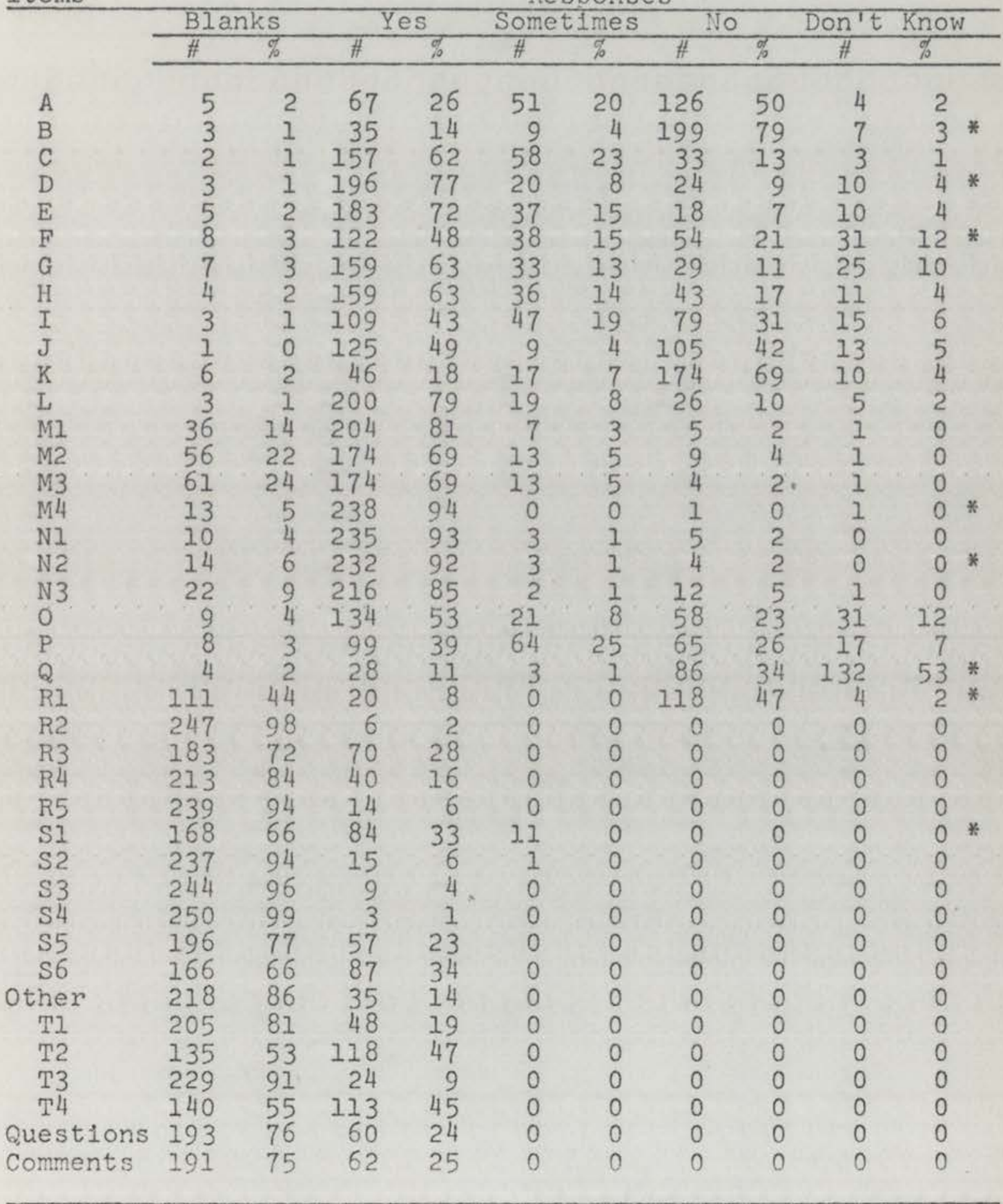

*Error due to rounding off 
TABLE 4 (continued)

Monte Vista School

Items

Responses

\begin{tabular}{|c|c|c|c|c|c|c|c|c|c|c|c|}
\hline & $\mathrm{BIa}$ & & & & Some & imes & & & Don $^{\prime} t$ & Know & \\
\hline & II & $\%$ & $\#$ & $\%$ & $\#$ & $\%$ & \# & $\%$ & $\#$ & & \\
\hline A & 4 & 1 & 71 & 24 & 45 & 15 & 174 & 58 & 7 & 2 & \\
\hline B & 2 & 1 & 48 & 16 & 21 & 7 & 220 & 73 & 10 & 3 & \\
\hline C & 2 & 1 & 197 & 65 & 54 & 18 & 42 & 14 & 6 & 2 & \\
\hline D & 1 & 1 & 233 & 77 & 26 & 9 & 32 & .11 & 9 & 3 & * \\
\hline E & 5 & 2 & 222 & 74 & 45 & 15 & 23 & 8 & 6 & 2 & * \\
\hline F & 6 & 2 & 168 & 56 & 53 & 18 & 48 & 16 & 26 & 9 & * \\
\hline G & 6 & 2 & 173 & 57 & 50 & 17 & 42 & 14 & 30 & 10 & \\
\hline $\mathrm{H}$ & 1 & 0 & 196 & 65 & 55 & 18 & 40 & 13 & 9 & 3 & * \\
\hline I & 1 & 0 & 159 & 53 & 41 & 14 & 85 & 28 & 15 & 5 & \\
\hline $\mathrm{J}$ & 1 & 0 & 147 & 49 & 16 & 5 & 120 & 40 & 17 & 6 & \\
\hline K & 2 & 1 & 48 & 16 & 17 & 6 & 218 & 72 & 16 & 5 & \\
\hline L & 3 & $I$ & 248 & 82 & 20 & 7 & 25 & 8 & 5 & 2 & \\
\hline MI & 44 & 15 & 248 & 82 & 7 & 2 & 2 & 1 & 0 & 0 & \\
\hline M2 & 68 & 23 & 219 & 73 & 7 & 2 & 6 & 2 & 1 & 0 & \\
\hline M3 & 70 & 23 & 214 & 71 & 11 & 4 & 4 & 1 & 2 & 1 & \\
\hline M4 & 10 & 3 & 291 & 97 & 0 & 0 & 0 & $0^{\circ}$ & 0 & 0 & \\
\hline $\mathrm{NI}$ & 7 & 2 & 287 & 95 & 2 & 1 & 4 & 1 & 1 & 0 & * \\
\hline N2 & 11 & 4 & 281 & 93 & 2 & 1 & 6 & 2 & 1 & 0 & \\
\hline N3 & 23 & 8 & 267 & 89 & 2 & 1 & 8 & 3 & 1 & 0 & * \\
\hline 0 & 1 & 0 & 182 & 60 & 26 & 9 & 65. & 22. & 27. & 9 & \\
\hline P & 3 & 1 & 142 & 47 & 51 & 17 & 87 & 29 & 18 & 6 & \\
\hline Q & 4 & 1 & 16 & 5 & 3 & 1 & 81 & 27 & 197 & 65 & * \\
\hline RI & 106 & 35 & 28 & 9 & 0 & 0 & 164 & 54 & 3 & 1 & * \\
\hline R2 & 288 & 96 & 11 & 4 & 0 & 0 & 2 & 1 & 0 & 0 & * \\
\hline R3 & 252 & 84 & 49 & 16 & 0 & 0 & 0 & 0 & 0 & 0 & \\
\hline R4 & 260 & 86 & 41 & 14 & 0 & 0 & 0 & 0 & 0 & 0 & \\
\hline R5 & 291 & 97 & 10 & 3 & 0 & 0 & 0 & 0 & 0 & 0 & \\
\hline S. & 245 & 81 & 55 & 18 & 0 & 0 & 0 & 0 & 0 & 0 & \\
\hline S2 & 235 & 76 & 65 & 22 & 0 & 0 & 0 & 0 & 1 & 0 & \\
\hline \$3 & 260 & 86 & 40 & 13 & 0 & 0 & 0 & 0 & 1 & 0 & * \\
\hline S4 & 292 & 97 & 8 & 3 & 0 & 0 & 0 & 0 & 1 & 0 & \\
\hline S5 & 170 & 56 & 130 & 43 & 0 & 0 & 0 & 0 & 1 & 0 & $*$ \\
\hline s6 & 284 & 94 & 16 & 5 & 0 & 0 & 0 & 0 & 1 & 0 & * \\
\hline ther & 277 & 92 & 24 & 8 & 0 & 0 & 0 & 0 & 0 & 0 & \\
\hline $\mathrm{TI}$ & 258 & 86 & 43 & 14 & 0 & 0 & 0 & 0 & 0 & 0 & \\
\hline $\mathrm{T} 2$ & 144 & 48 & 157 & 52 & 0 & 0 & 0 & 0 & 0 & 0 & \\
\hline T3 & 239 & 79 & 62 & 21 & 0 & 0 & 0 & 0 & 0 & 0 & \\
\hline T4 & 195 & 65 & 106 & 35 & 0 & 0 & 0 & 0 & 0 & 0 & \\
\hline Questions & 242 & 80 & 59 & 20 & 0 & 0 & 0 & 0 & 0 & 0 & \\
\hline Comments & 232 & 77 & 69 & 23 & 0 & 0 & 0 & 0 & 0 & 0 & \\
\hline
\end{tabular}


TABLE 4 (continued)

\section{Carlos Rey School}

Items

Responses

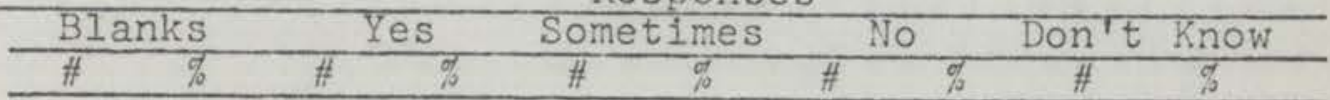

A

B
C
D
E
F
G
H
I
J
K
L

$\begin{array}{llll}3 & 1 & 129 & 33\end{array}$

33

$\begin{array}{lll}67 & 17 & 183\end{array}$

47

72

$\begin{array}{lll}7 & 2 & 106 \\ 6 & 2 & 285\end{array}$

73

$\begin{array}{lll}37 & 10 & 218\end{array}$

$\begin{array}{lll}18 & 56 & -21 \\ 11 & 11 & 4\end{array}$

$\begin{array}{lll}2 & 1 & 318\end{array}$

82

53

14

$40 \quad 10$

80

19

540

$57 \quad 36$

11

20

69

38

10

55

5
22

10

$\begin{array}{lll}7 & 2 & 220 \\ 6 & 2 & 267\end{array}$

71

$47 \quad 12$

48

14

39

$\begin{array}{ll}70 & 18\end{array}$

112

12

23

45

$\begin{array}{ll}69 & 11 \\ 28 & 23\end{array}$

3

231

29

1.5

$23 \quad 15$

2
5
$1 *$
3

MI

M2

125

$\begin{array}{ll}1 & 109 \\ 1 & 337\end{array}$

$87 \quad 23$

21

68
64

1

M3

$\mathrm{M} 4$

NI

139

36

263

$\begin{array}{lr}6 & 21 \\ 0 & 0\end{array}$

6119

52

36

N2

15

8. 201

91

$\begin{array}{lll}9 & 353 & 91 \\ 4 & 374 & 96\end{array}$

0

N3

0

P

Q

RI

22.

$\begin{array}{lll}6 & 366 & 94\end{array}$

$\begin{array}{llll}30 & 8 & 357 & 92 \\ 11 & 3 & 290 & 75\end{array}$

$\begin{array}{ll}3 & 290 \\ 1 & 276\end{array}$

75

0

0

0

3
8

2

29

7151

1
19
51

7

371

38

15

12

7
0

R3

R4

R5

SI

310

85

79

20

$\begin{array}{lll}86 & 56 & 14\end{array}$

374

9615

14

329

85

60

15

$\begin{array}{lll}90 & 37 & 10\end{array}$

256

371

$\begin{array}{ll}66 & 133\end{array}$

34

S4

S5

S6

Other

$\mathrm{TI}$

T2

201

95

18

5.0

$\begin{array}{llll}52 & 188 & 48 & 0\end{array}$

$\begin{array}{lll}375 & 96 & 14 \\ 374 & 96 & 15\end{array}$

T3

237

$61 \quad 152$

4

0
0

69121

39

31

324

$\begin{array}{lll}83 & 65 & 17\end{array}$

$\begin{array}{lllll}T 4 & 250 & 64 & 139 & 36\end{array}$

$\begin{array}{lllll}T 4 & 250 & 64 & 139 & 36\end{array}$

$\begin{array}{lllll}T 4 & 250 & 64 & 139 & 36\end{array}$

Questions $326 \quad 84 \quad 63 \quad 16$

$\begin{array}{lllll}\text { Comments } & 327 & 84 & 62 & 16\end{array}$

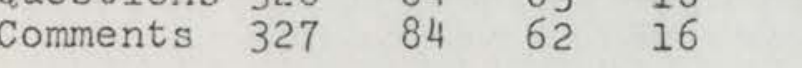

0

0

0

0

0
5
3

13

2

151

193

54

$\begin{array}{ll}0 & 0 \\ 0 & 0\end{array}$

0 .

0
0

$\begin{array}{lll}0 & 0\end{array}$

0

1

$\begin{array}{rrr}39 & 10 & 30\end{array}$

$\begin{array}{lll}41 & 11 & 18\end{array}$

$39 \quad 194$

0

3

50

6

4

$\frac{4}{5} *$

5

1

0

0

0

0

$8 \%$

$5 *$

50

$1 *$

0

$\begin{array}{llllll}0 & 0 & 0 & 0 & 0 & 0 \\ 0 & 0 & 0 & 0 & 0 & 0\end{array}$ 
TABLE 4 (continued)

\section{Chelwood School}

Items Responses

\begin{tabular}{|c|c|c|c|c|c|c|c|c|c|c|c|}
\hline & $\mathrm{BI}$ & & & & Some & imes & & & $D^{\prime} n^{\prime} t$ & Know & \\
\hline & $\#$ & $\%$ & $\#$ & $\%$ & $\#$ & $\%$ & \# & $\%$ & $\#$ & $\%$ & \\
\hline A & 4 & 1 & 65 & 21 & 59 & 19 & 176 & 56 & 9 & 3 & \\
\hline B & 4 & 1 & 46 & 15 & 19 & 6 & 225 & 72 & 19 & 6 & \\
\hline C & 4 & $\bar{I}$ & 194 & 62 & 57 & 18 & 51 & 16 & 7 & 2 & * \\
\hline D & 3 & 1 & 250 & 80 & 21 & 7 & 26 & 8 & 13 & 4 & \\
\hline E & 4 & 1 & 221 & 71 & 53 & 17 & 27 & 9 & 8 & 3 & * \\
\hline F & 4 & 1 & 134 & 43 & 48 & 15 & 91 & 29 & 36 & 12 & \\
\hline G & 3 & 1 & 174 & 56 & 46 & 15 & 56 & 18 & 34 & 11 & * \\
\hline $\mathrm{H}$ & 3 & 1 & 271 & 67 & 42 & 13 & 45 & 14 & 12 & 4 & * \\
\hline I & 4 & 1 & 143 & 46 & 49 & 16 & 98 & 31 & 19 & 6 & \\
\hline $\bar{J}$ & 3 & 1. & 151 & 48 & 17 & 5 & 123 & 39 & 19 & 6 & * \\
\hline K & 3 & 1 & 40 & 13 & 20 & 6 & 239 & 76 & 11 & 4 & \\
\hline L & 9 & 3 & 256 & 82 & 19 & 6 & 26 & 8 & 3 & 1 & \\
\hline MI & 43 & 14 & 268 & 86 & 1 & 0 & 0 & 0 & I & 0 & \\
\hline M2 & 69 & 22 & 244 & 78 & 0 & 0 & 0 & 0 & 0 & 0 & \\
\hline M3 & 67 & 21 & 245 & 78 & 1 & 0 & 0 & 0 , & 0 & 0 & * \\
\hline M4 & 10 & 3 & 303 & 97 & 0 & 0 & 0 & 0 & 0 & 0 & \\
\hline NI & 8 & 3 & 305 & 97 & 0 & 0 & 0 & 0 & 0 & 0 & \\
\hline N2 & 15 & 5 & 298 & 95 & 0 & 0 & 0 & 0 & 0 & 0 & \\
\hline N3 & 26 & 8 & 287 & 92 & 0 & 0 & 0 & 0 & 0 & 0 & \\
\hline 0 & 10 & 3 & 154 & 49 & 28 & 9 & 85 & 27 & 36 & 12 & \\
\hline P & 8 & 3 & 114 & 36 & 71 & 23 & 93 & 31 & 22 & 7 & \\
\hline Q & 14 & 4 & 12 & 4 & 7 & 2 & 87 & 28 & 193 & 62 & \\
\hline RI & 107 & 34 & 39 & 12. & 0 & 0 & 165 & 53 & 2 & 1 & \\
\hline $\mathrm{R} 2$ & 298 & 95 & 12 & 4 & 0 & 0 & 3 & 1 & 0 & 0 & \\
\hline R3 & 258 & 82 & 55 & 18 & 0 & 0 & 0 & 0 & 0 & 0 & \\
\hline R4 & 279 & 89 & 34 & 11 & 0 & 0 & 0 & 0 & 0 & 0 & \\
\hline R5 & 306 & 98 & 7 & 2 & 0 & 0 & 0 & 0 & 0 & 0 & \\
\hline Si. & 255 & 81 & 58 & 19 & 0 & 0 & 0 & 0 & 0 & 0 & \\
\hline S2 & 263 & 84 & 50 & 16 & 0 & 0 & 0 & 0 & 0 & 0 & \\
\hline S3 & 272 & 87 & 41 & 13 & 0 & 0 & 0 & 0 & 0 & 0 & \\
\hline S4 & 305 & 97 & 8 & 3 & 0 & 0 & 0 & 0 & 0 & 0 & \\
\hline S5 & 180 & 58 & 133 & 42 & 0 & 0 & 0 & 0 & 0 & 0 & \\
\hline s6 & 290 & 93 & 23 & 7 & 0 & 0 & 0 & 0 & 0 & 0 & \\
\hline Other & 300 & 96 & 13 & 4 & 0 & 0 & 0 & 0 & 0 & 0 & \\
\hline T1 & 246 & 79 & 67 & 21 & 0 & 0 & 0 & 0 & 0 & 0 & \\
\hline T2 & 197 & 63 & 116 & 37 & 0 & 0 & 0 & 0 & 0 & 0 & \\
\hline T3 & 277 & 88 & 36 & 12 & 0 & 0 & 0 & 0 & 0 & 0 & \\
\hline $\mathrm{T} 4$ & 157 & 50 & 156 & 50 & 0 & 0 & 0 & 0 & 0 & 0 & \\
\hline Questions & 265 & 85 & 48 & 35 & 0 & 0 & 0 & 0 & 0 & 0 & \\
\hline Comments & 238 & 76 & 75 & 24 & 0 & 0 & 0 & 0 & 0 & 0 & \\
\hline
\end{tabular}


TABLE 4 (continued)

Acoma School

Items Responses

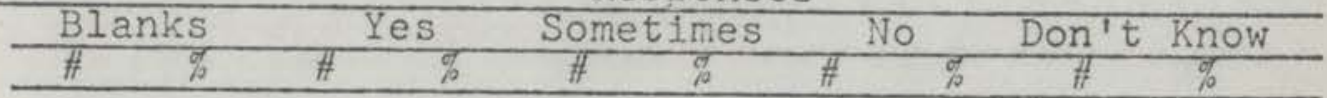

A

B

C

D

E

G

$\mathrm{H}$

J

K

L

MI

M2

M3

M4

NI

N2

N3

P

Q

RI

$\mathrm{R} 2$

R3

R5

SI

S2

53

S4

S5

S6

other

TI

T2

T3

T4

Questions 179

Comments 186

$\begin{array}{llll}6 & 3 & 66 & 31\end{array}$

$\begin{array}{llll}8 & 4 & 46 & 21\end{array}$

$\begin{array}{lll}3 & 1 & 136\end{array}$

63

31169

21155

78

$\begin{array}{rr}37 & 17 \\ 18 & 8 \\ 37 & 17\end{array}$

99

46

$\begin{array}{llll}37 & 17 & 34 & 16\end{array}$

$\begin{array}{ll}72 & 29\end{array}$

$\begin{array}{lll}7 & 24 & 11\end{array}$

$\begin{array}{ll}56 & 28\end{array}$

$\begin{array}{lll}13 & 21 & 10\end{array}$

$\begin{array}{lll}60 & 35 & 16\end{array}$

$40 \quad 19$

$\begin{array}{lllll}60 & 35 & 16 & 31 & 14 \\ 63 & 40 & 19 & 27 & 13\end{array}$

130

$40 \quad 19$

27

61

13

6

$22 \quad 13$

$\begin{array}{ll}52 & 29 \\ 57 & 26\end{array}$

82

7
78

143

68

18

23

$\begin{array}{llll}60 & 17 & 8 & 11\end{array}$

$\begin{array}{ll}56 & 26 \\ 60 & 28\end{array}$

130

127

59. 18

$\begin{array}{lll}9 & 4 & 203\end{array}$

94

1

91

10

197

90

12

181

84

7

147

68

49

$25 \quad 12$

66

31

44

20

146

156

72

57

26

193

89

19

9

12
35

$\begin{array}{ll}180 & 83 \\ 195 & 90\end{array}$

16

21

10

202
198

94

13

6

6

0
3
2
3
8

7
18

92

113

52

102

8

38

18

5
13
26

10

3

5
13
26

48

62

2

3
1

94

12

22

29

8

$4 *$

$\begin{array}{lllll}195 & 90 & 21 & 10 & 0\end{array}$

$\begin{array}{lllll}178 & 82 & 38 & 18 & 0\end{array}$

$\begin{array}{lllll}158 & 73 & 58 & 27 & 0\end{array}$

$\begin{array}{llll}143 & 66 & 72 & 33\end{array}$

44

14

$6 *$

8

31

1

1

0

0

.0

0

0

0 
TABLE 4 (continued)

\section{Comanche School}

Items Responses

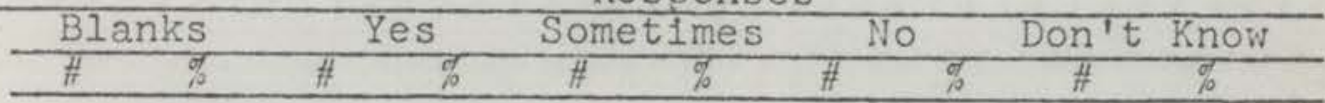

A

B

C

D

E

F

G

I

I

K

$\begin{array}{lllllll}7 & 2 & 78 & 27 & 54 & 19 & 147\end{array}$

$\begin{array}{lllllll}5 & 2 & 42 & 14 & 18 & 6 & 199\end{array}$

$\begin{array}{lllllll}3 & 1 & 167 & 57 & 53 & 18 & 63\end{array}$

51

$\begin{array}{rr}68 & 57 \\ 27\end{array}$

$\begin{array}{llll}5 & 2 & 203 & 70\end{array}$

$40 \quad 14$

30

22

5

$\begin{array}{llll}5 & 2 & 197 & 68\end{array}$

1930

10

13

$\begin{array}{lll}7 & 2 & 141\end{array}$

48

54
53

1856

812

2161

55
63

49 17. 44

$19 \quad 34$

$\begin{array}{lll}3 & 1 & 182\end{array}$

42

14

15

2 125

43

53

18

53

18

30

$\begin{array}{rrr}3 & 1 & 119 \\ 4 & 1 & 46\end{array}$

41
16

7
5

$2 \quad 142$

$32 \quad 14$

49

20

$81 \quad 10$

2220

$\begin{array}{ll}76 & 16\end{array}$

$2 *$

MI

M2

36

12

215

74

$\begin{array}{rrrr}74 & 31 & 11 & 9 \\ 59 & 47 & 16 & 16\end{array}$

$\begin{array}{lll}3 & 38 & 13\end{array}$

M3

$57 \cdot 20 \cdot 170$

58

14

18

$\begin{array}{rrr}9 & 3 & 279 \\ 14 & 5 & 260\end{array}$

96

89

42

$\begin{array}{ll}1 & 0 \\ 2 & 8\end{array}$

N2

10

3264

N3

25

$9 \frac{1}{8}$

3
6

0

$\mathrm{P}$

Q

RI

$\begin{array}{ll}7 & 2 \\ 7 & 136\end{array}$

78

\begin{tabular}{l}
5 \\
5 \\
\hline
\end{tabular}

2

25

185

29

16

5. 106

4

116

5

105

190

273

33

65

22

$7 \frac{1}{3}$

$0 \quad 126$

R3

202

69

86

2

10

249

86

R5

280

39

30

1

3
5
6
0
3
3
36
36
36

1

9 *

S1

242

96

7

13

3

S2

S3

259

83

49

17

32

11

$95 \quad 15$

283

S5

S6

129

97

7

5

2.1

161

55

17

6

274

94

17

6

TI.

T2

230

79

60

21

111

38

241

83

49

17

T4

180

62

110

38

53

18

74

75

26

0

0

0

3
4

Comments 216

*Error due to rounding off 
APPENDIX D 


\section{TABLE 1}

SOCIAL CLASS OF PARENTS AT PAJARITO

ELEMENTARY SCHOOL

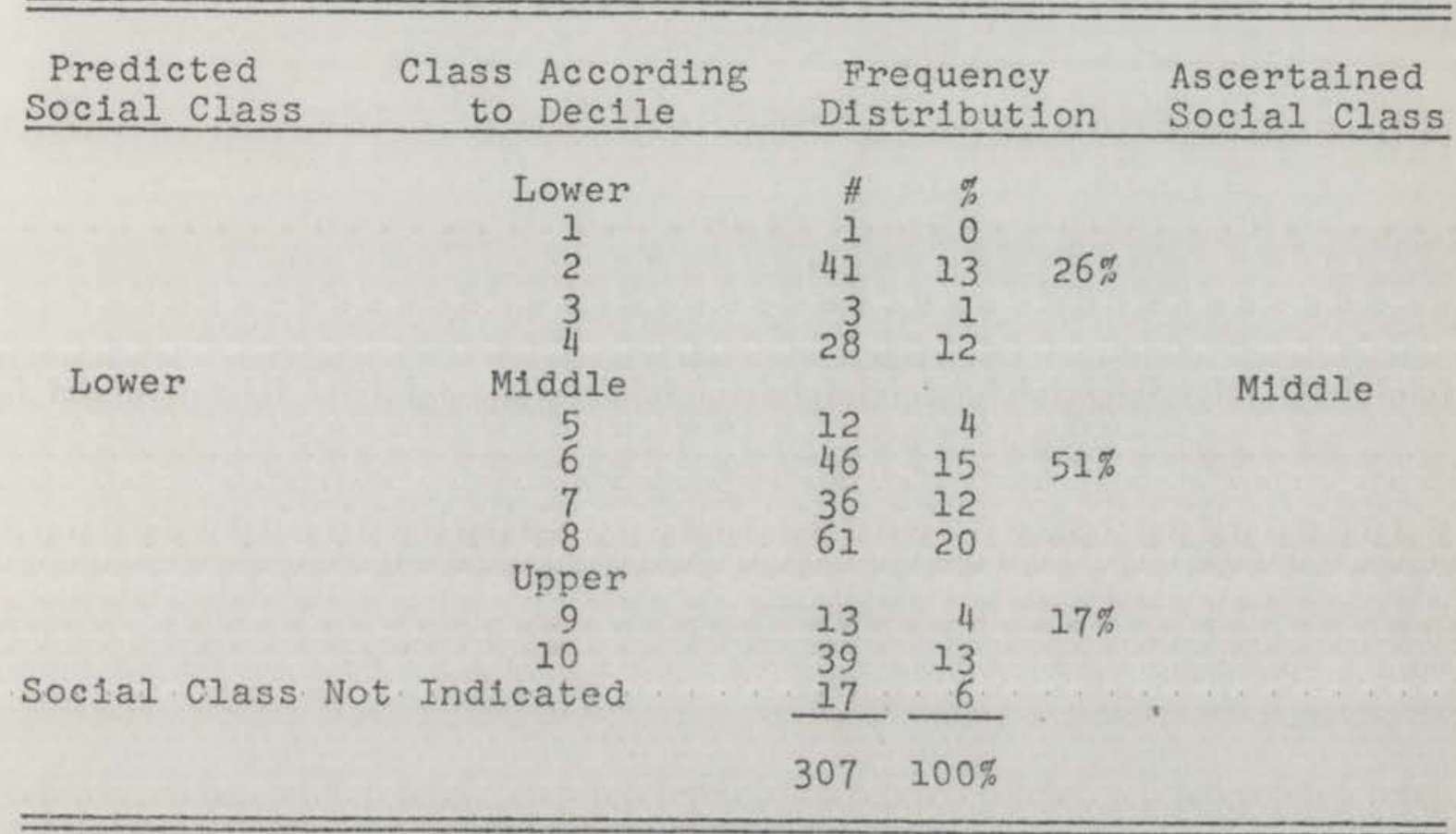




\section{TABLE 2}

SOCIAL CLASS OF PARENTS AT CORONADO

ELEMENTARY SCHOOL

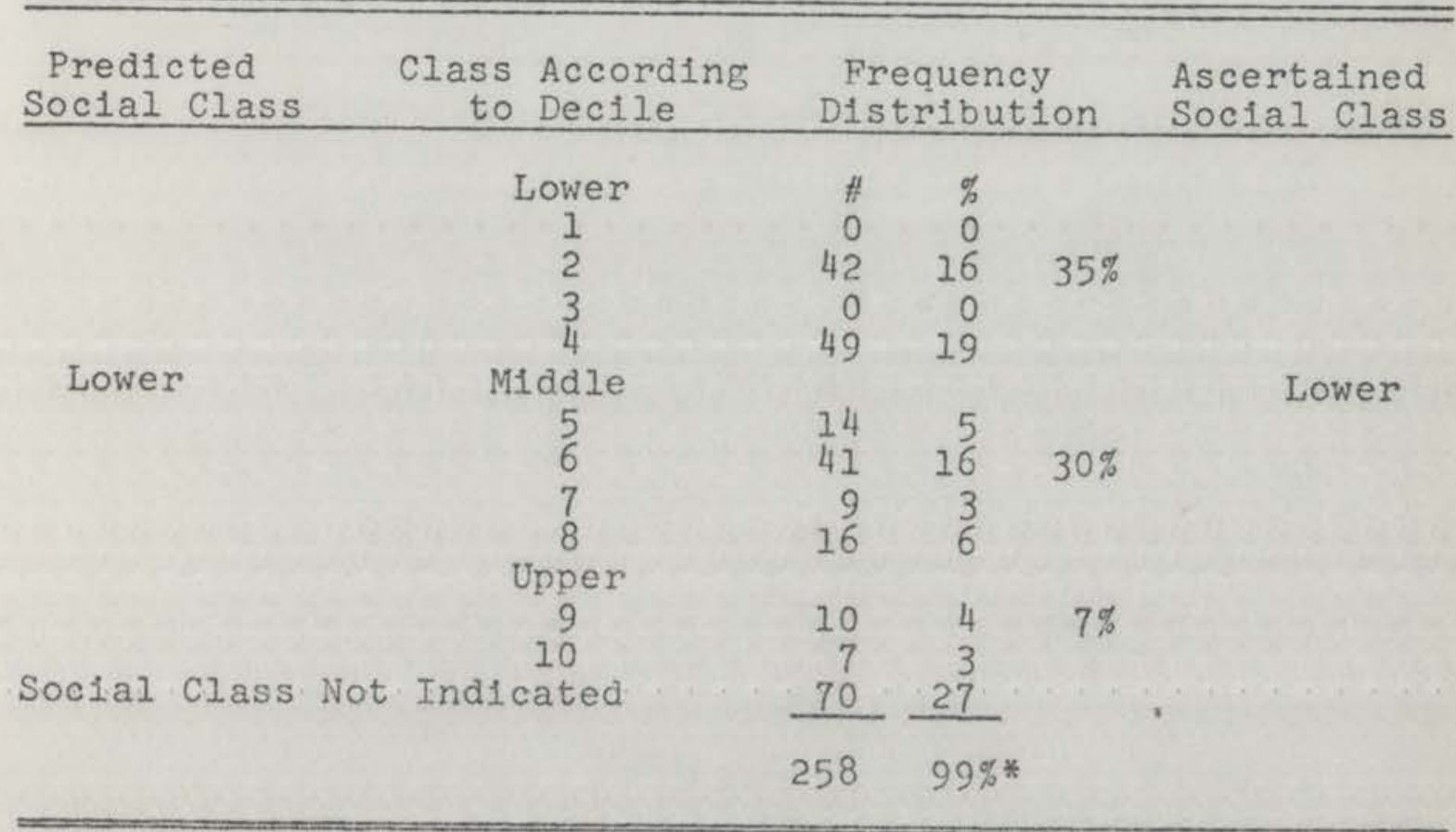

*Error due to rounding off 


\section{TABLE 3}

SOCIAL CLASS OF PARENTS AT DURANES

ELEMENTARY SCHOOL

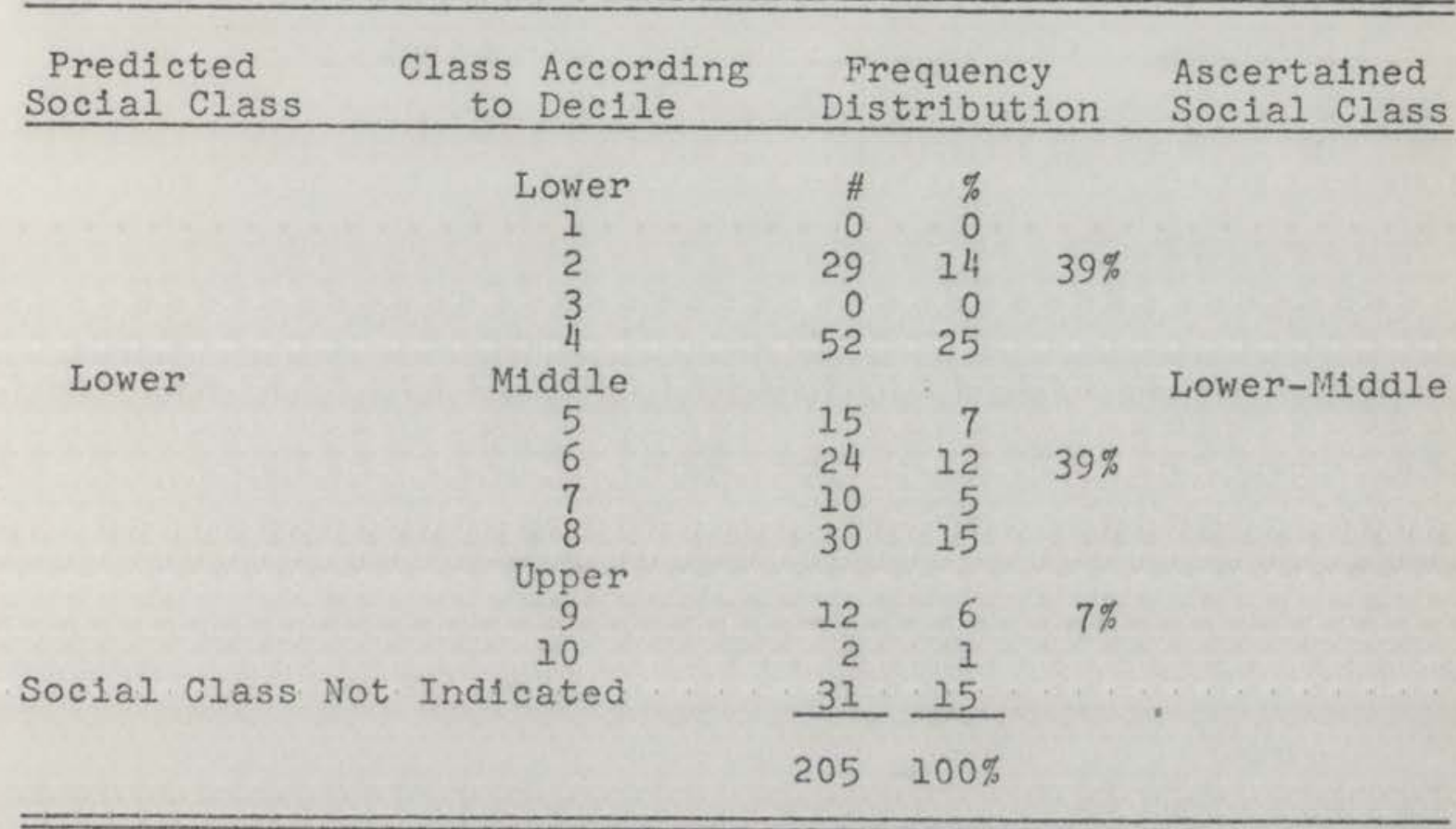




\section{TABLE 4}

SOCIAL CLASS OF PARENTS AT INEZ

ELEMENTARY SCHOOL

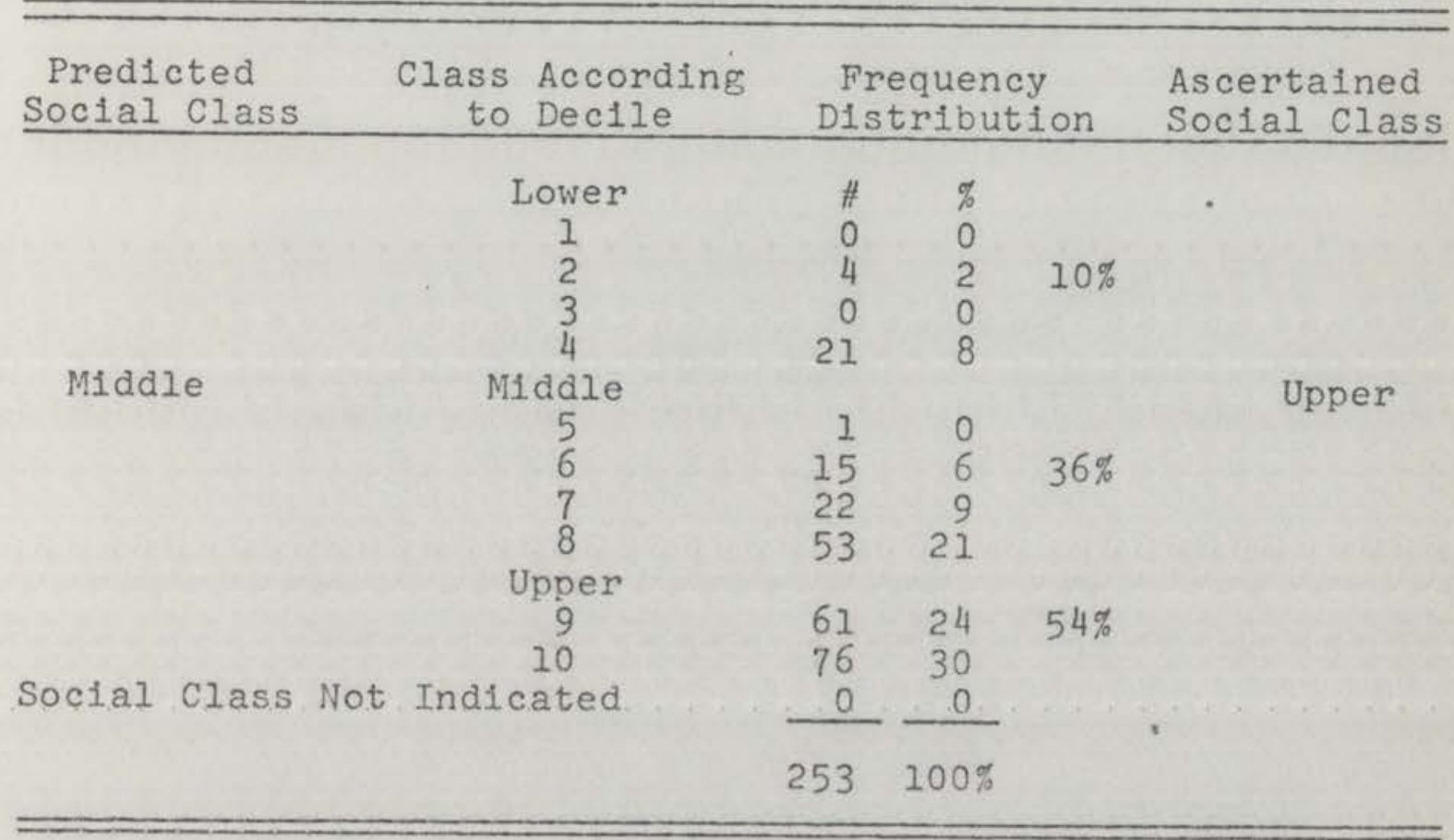




\section{TABLE 5}

SOCIAL CLASS OF PARENTS AT MONTE VISTA

ELEMENTARY SCHOOL

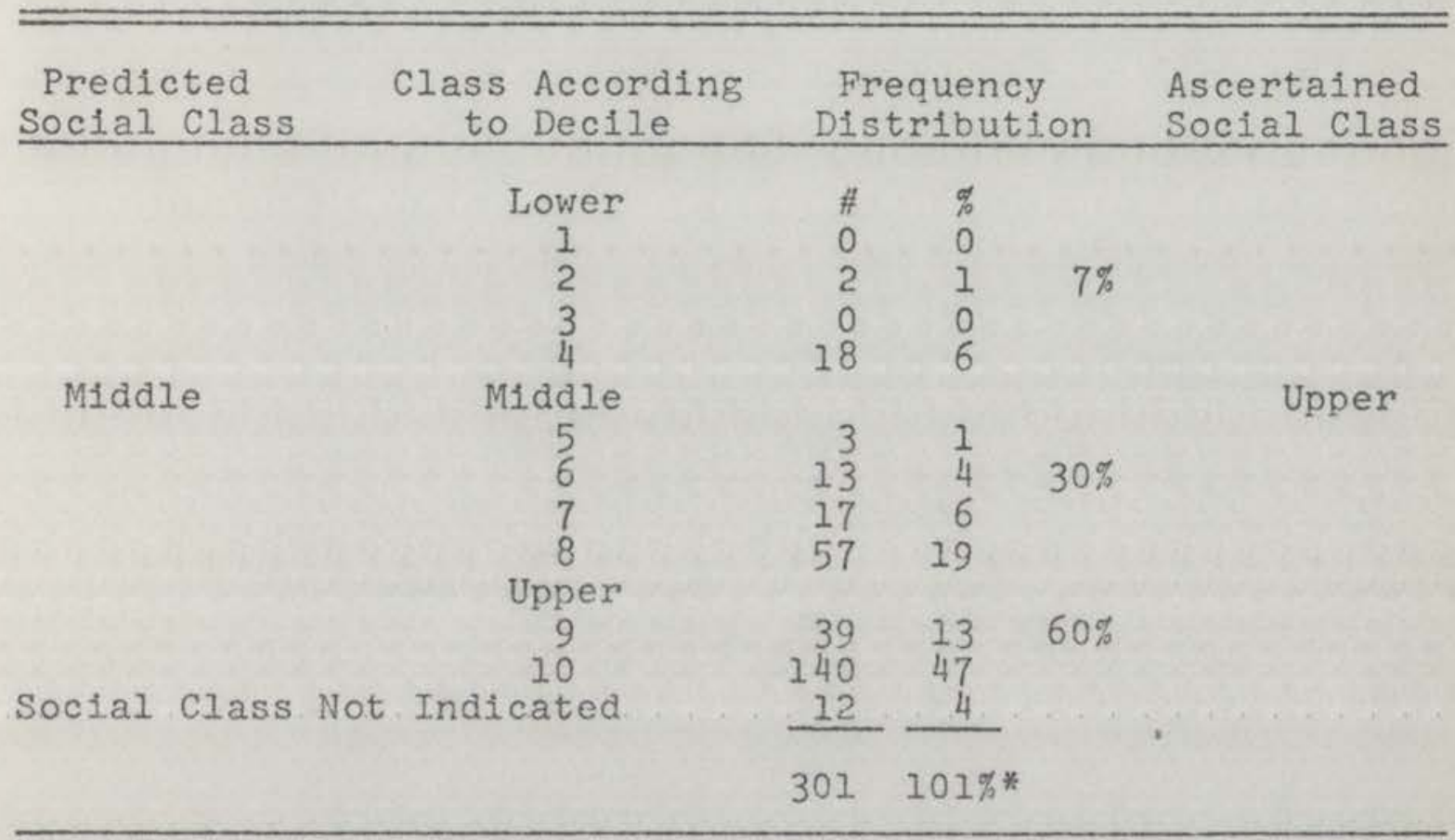

*Error due to rounding off 
TABLE 6

SOCIAL CLASS OF PARENTS AT CARLOS REY ELEMENTARY SCHOOL

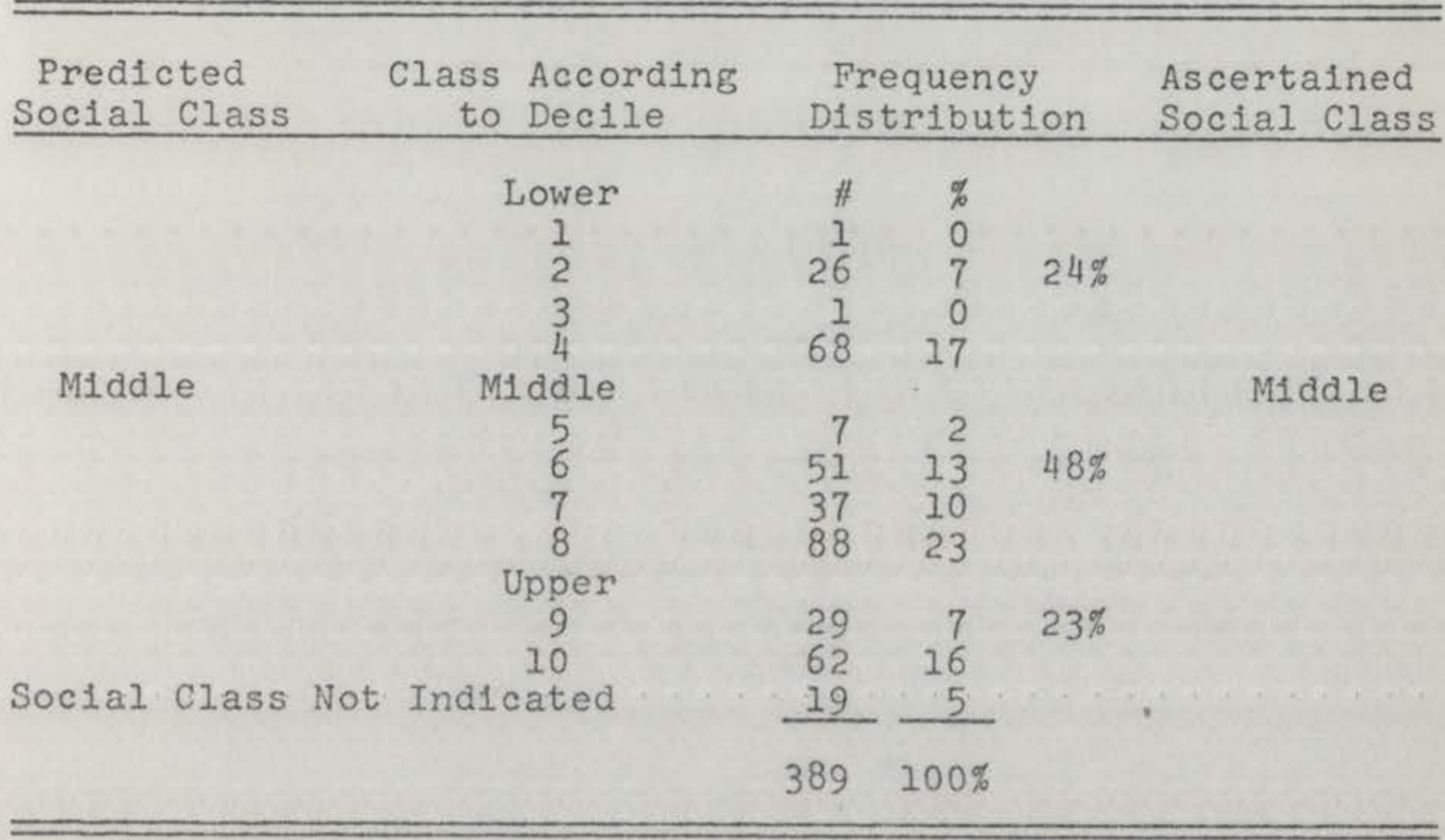




\section{TABLE 7}

SOCIAL CLASS OF PARENTS AT CHELWOOD ELEMENTARY SCHOOL

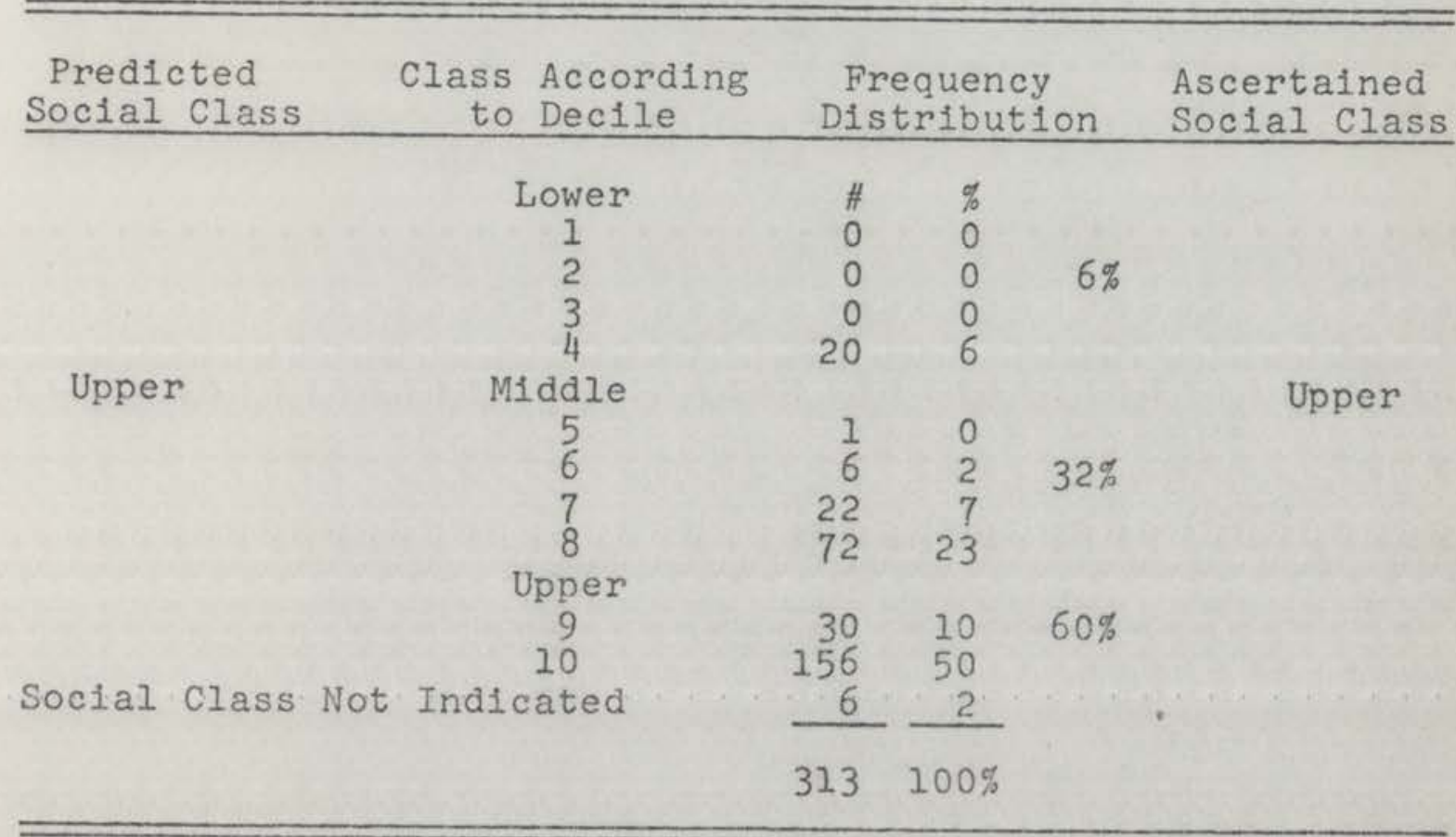


TABLE 8

SOCIAL CLASS OF PARENTS AT ACOMA

ELEMENTARY SCHOOL

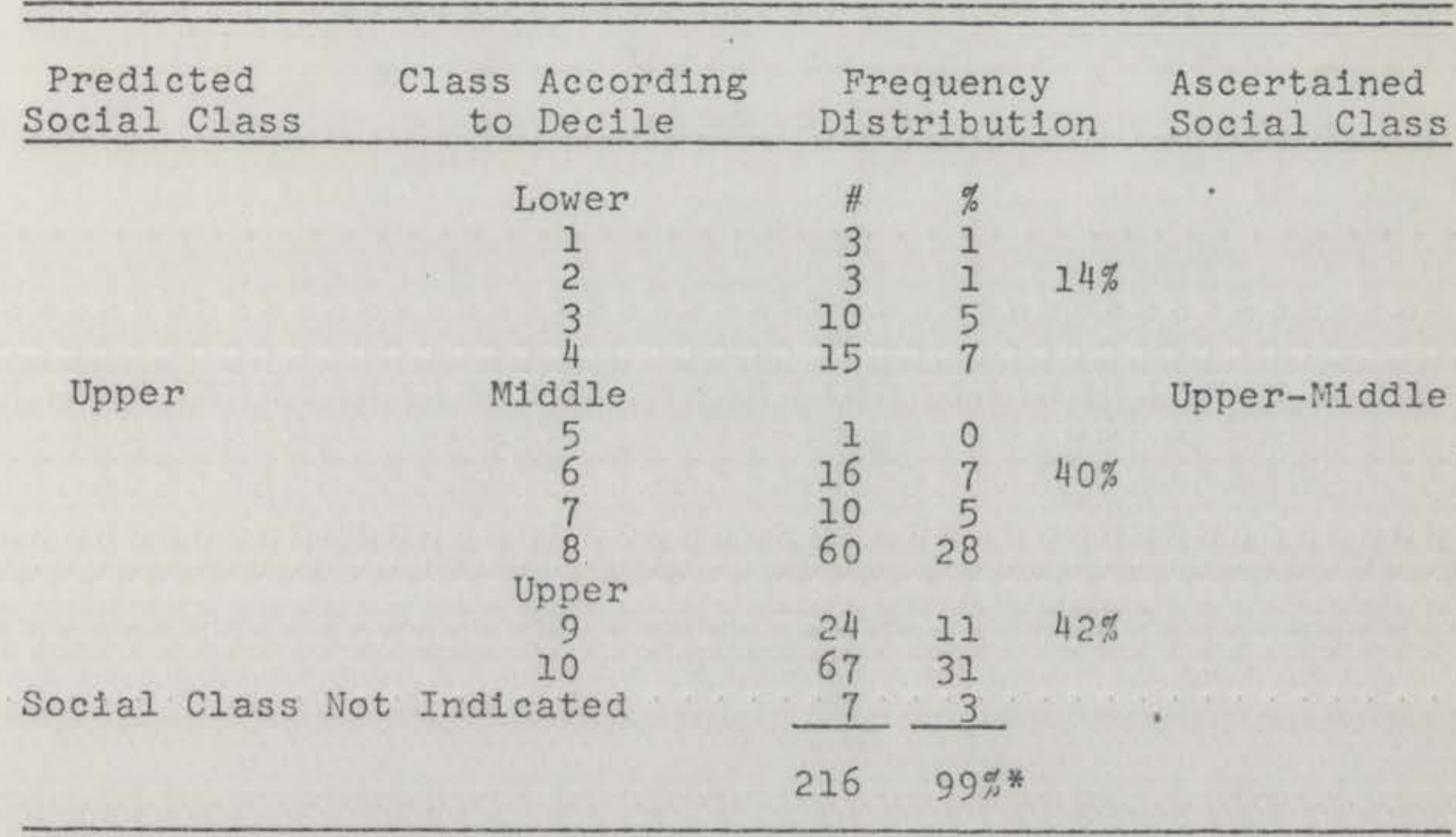

*Error due to rounding off 


\section{TABLE 9}

SOCIAL CLASS OF PARENTS AT COMANCHE ELEMENTARY SCHOOL

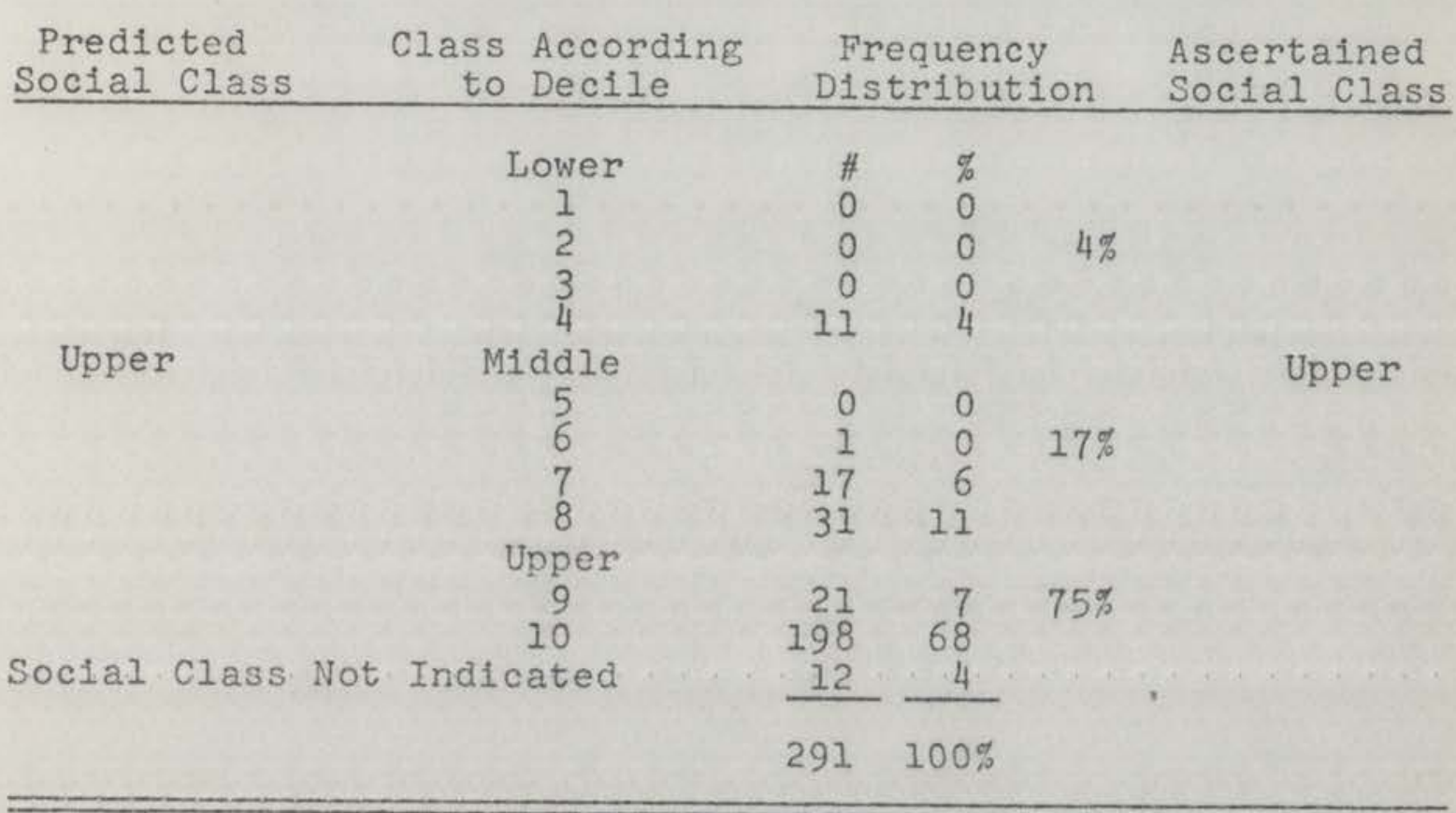


APPENDIX E 
SIGNIFICANT CHI SQUARE MATRICES

$\underline{\text { Item A }}$

\begin{tabular}{|c|c|c|c|c|c|c|c|}
\hline & Low & & Middle & & Upper & & \\
\hline & 182.3 & E & 366.1 & E & 273.6 & & \\
\hline 0 & 186 & 0 & 290 & 0 & 310 & ${ }^{*} \mathrm{LS}=$ & .001 \\
\hline & 3.7 & & 76.1 & & 36.4 & $* * x^{2}=$ & $=79.411$ \\
\hline & 166.7 & E & 334.9 & $\mathrm{E}$ & 217.4 & $* *$ DF $=$ & $=2$ \\
\hline & 163 & 0 & 411 & 0 & 145 & & \\
\hline & 3.7 & & 76.1 & & 72.4 & & \\
\hline
\end{tabular}

Item B

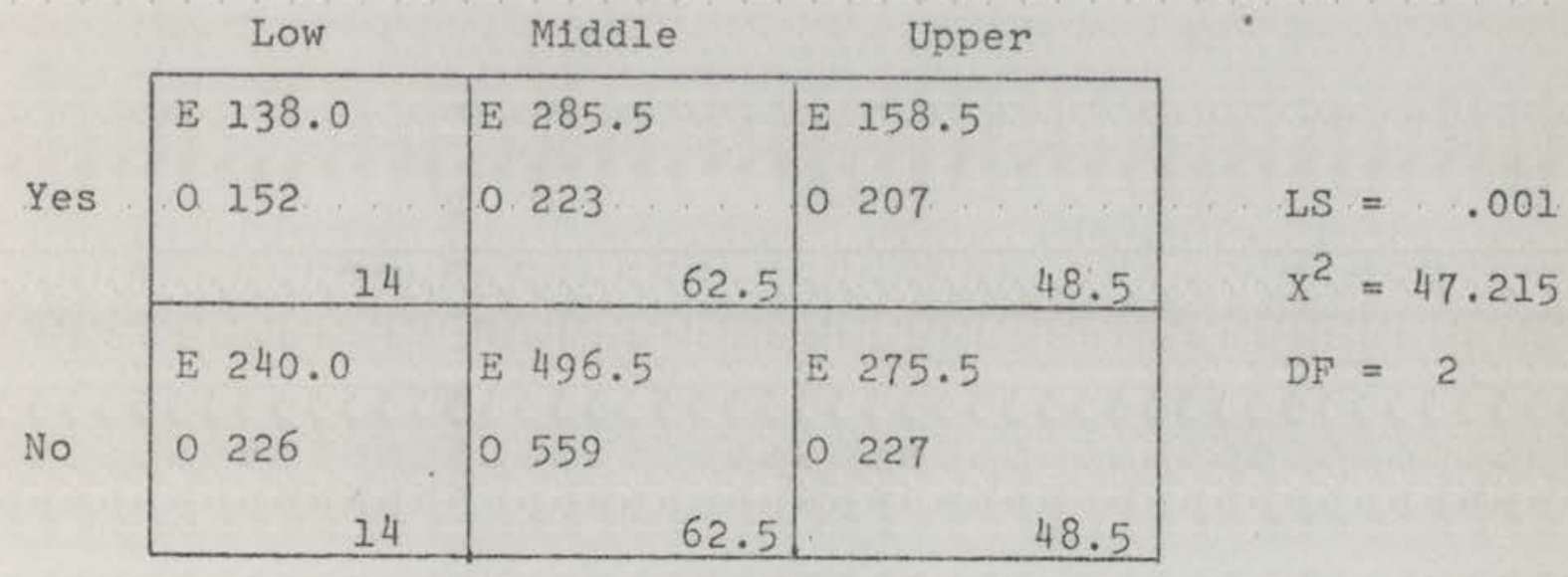

$E=$ Expected

$0=$ observed

${ }^{*} \mathrm{LS}=$ Level of Significance

$* * \mathrm{X}^{2}=$ Chi Square

$* * \mathrm{DF}=$ Degrees of Freedom 


\section{Item C}

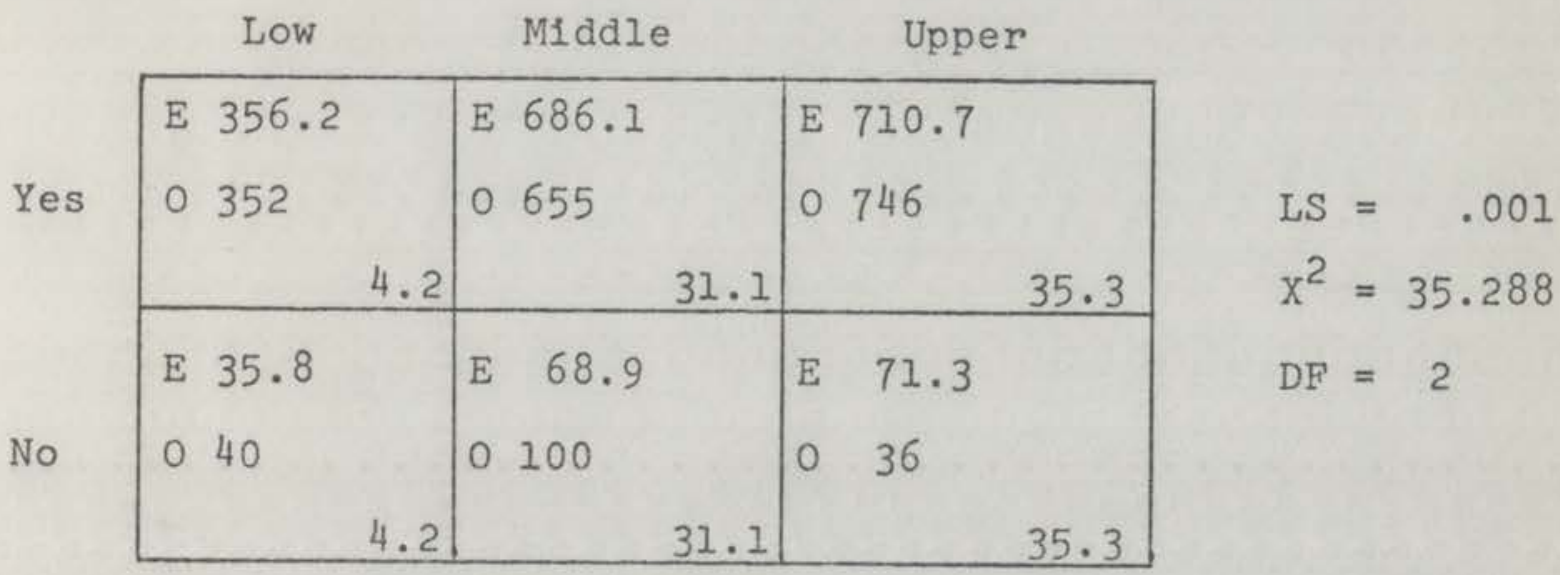

Item D

\begin{tabular}{|c|c|c|c|c|c|c|c|c|}
\hline & & Low & & Midale & & Upper & & \\
\hline & E & 369.8 & E & 729.7 & E & 861.5 & & \\
\hline Yes & 0 & 366 & 0 & 709 & 0 & 886 & LS & $=.001$ \\
\hline & & 3.8 & & 20.7 & & 24.5 & $x^{2}$ & $=14.526$ \\
\hline & E & 37.2 & E & 73.3 & & 86.5 & DF & $=2$ \\
\hline & 0 & 41 & 0 & 94 & & 62 & & \\
\hline & & 3.8 & & 20.7 & & 24.5 & & \\
\hline
\end{tabular}


Item $\mathrm{E}$

\begin{tabular}{|c|c|c|c|c|c|c|c|c|c|}
\hline & & Low & & Middle & & & Upper & & \\
\hline & E & 383.6 & $E$ & 726.7 & & $E$ & 835.7 & & \\
\hline Yes & 0 & 381 & 0 & 717 & & 0 & 848 & $\mathrm{LS}=$ & .10 \\
\hline & & 2.6 & & & 9.7 & & 72.3 & $x^{2}=$ & 5.444 \\
\hline & E & 24.4 & E & 46.3 & & E & 53.3 & $\mathrm{DF}=$ & 2 \\
\hline . & 0 & 27 & 0 & 56 & & 0 & 41 & 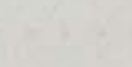 & \\
\hline & & 2.6 & & & 9.7 & & 12.3 & & \\
\hline
\end{tabular}

Item F

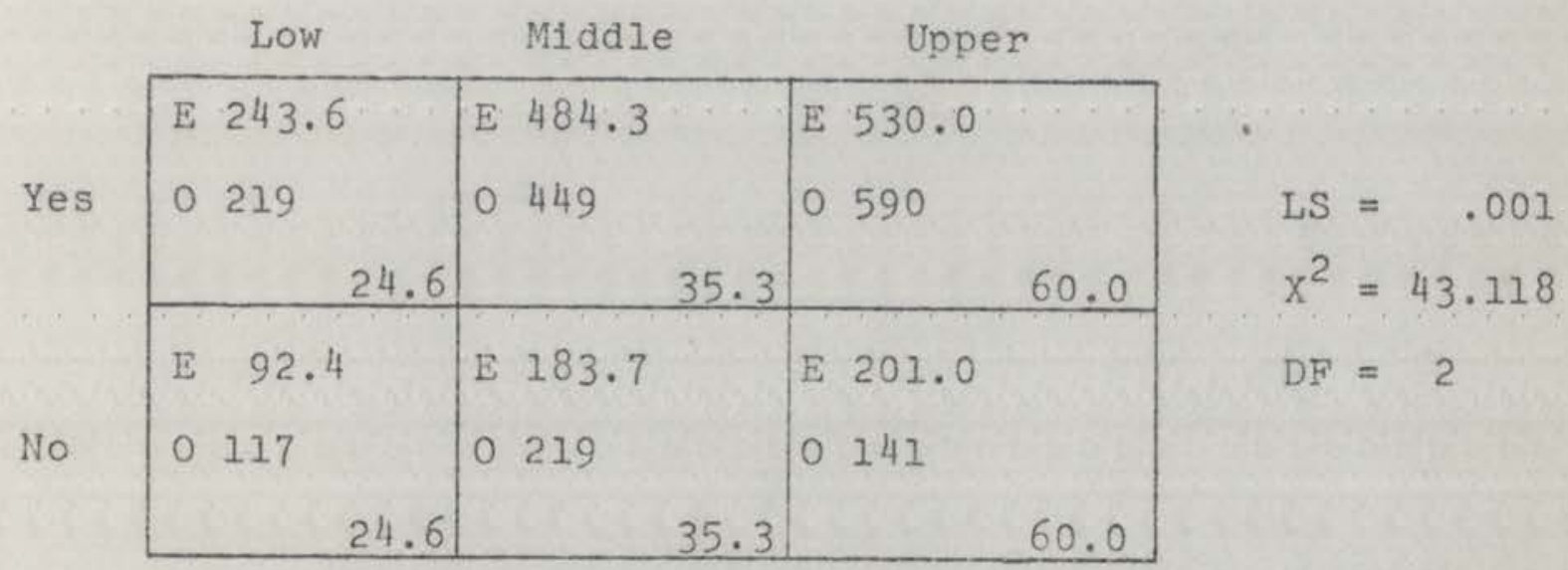


Item $G$

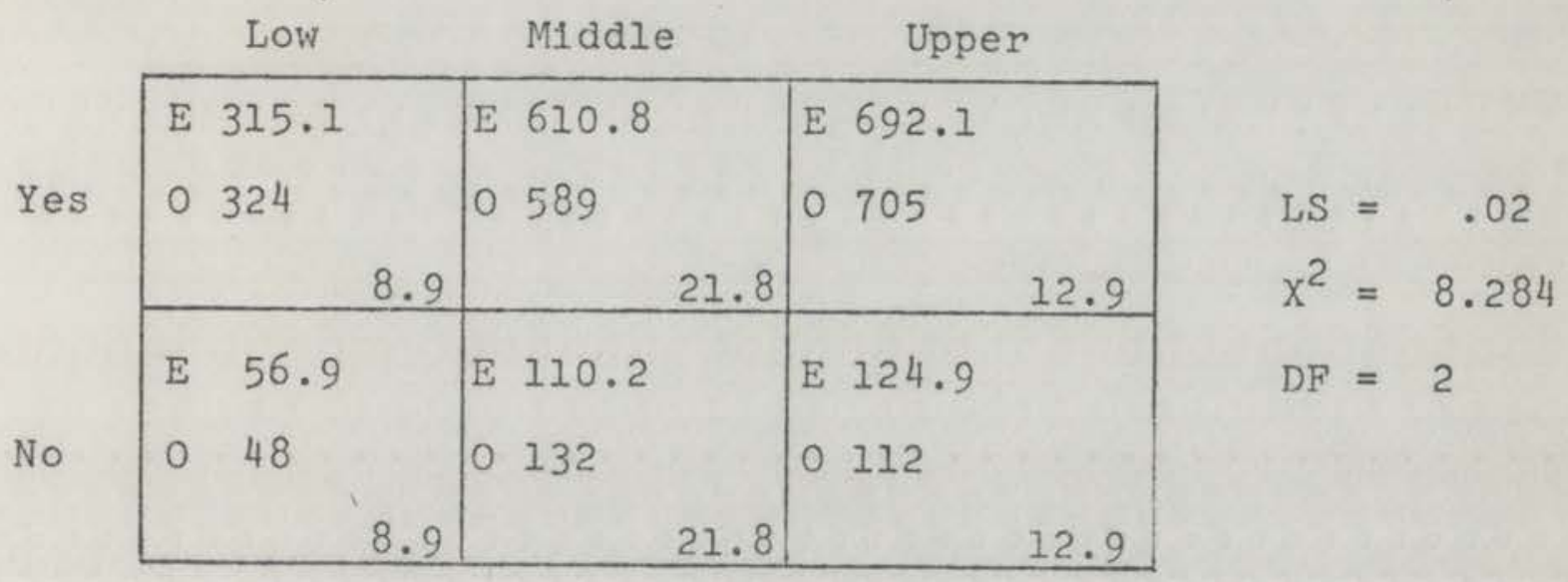

Item $\mathrm{H}$

\begin{tabular}{|c|c|c|c|c|c|c|c|}
\hline & & Low & & Middle & & Upper & \\
\hline & $\mathrm{E}$ & 322.5 & E & 643.2 & & 698.4 & . \\
\hline Yes & 0 & 320 & 0 & 614 & 0 & 730 & $L S=$ \\
\hline & & 2.5 & & 29.2 & & 31.6 & $x^{2}=22.416$ \\
\hline & E & 45.5 & E & 90.8 & E & 98.6 & $D F=2$ \\
\hline , & 0 & 48 & 0 & 120 & 0 & 67 & \\
\hline & & 2.5 & & 29.2 & & 31.6 & \\
\hline
\end{tabular}


Item I

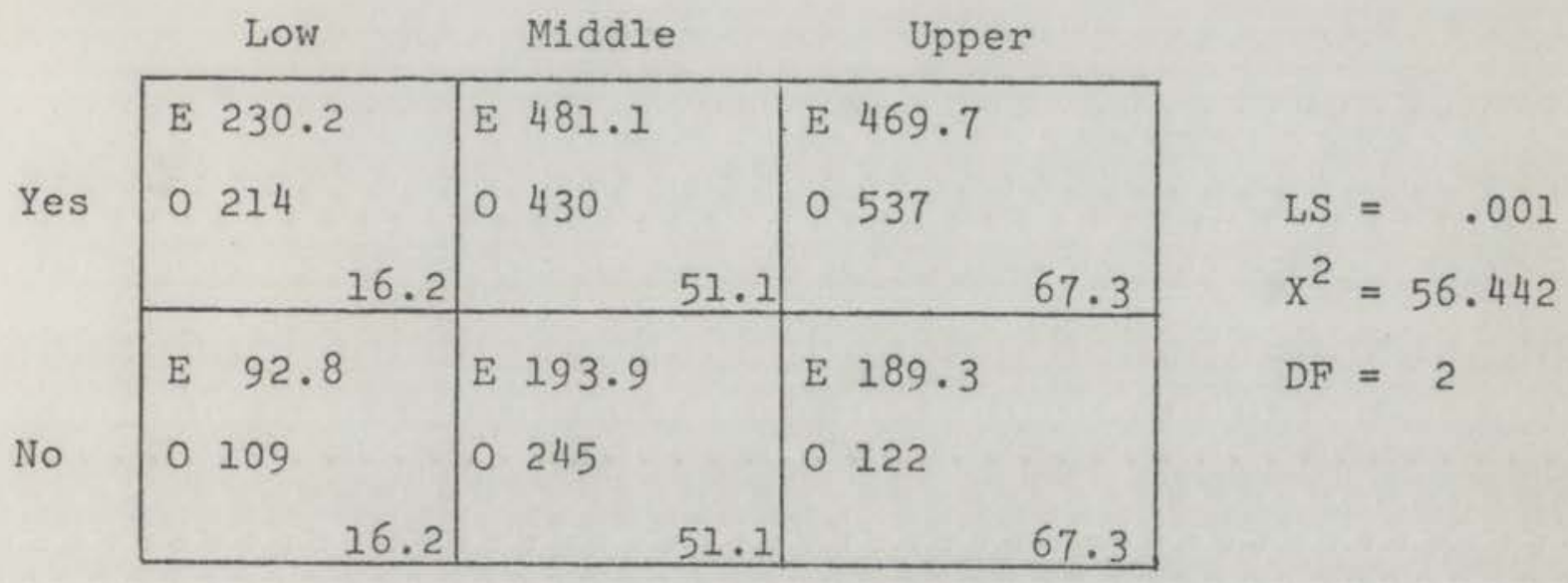

Item J

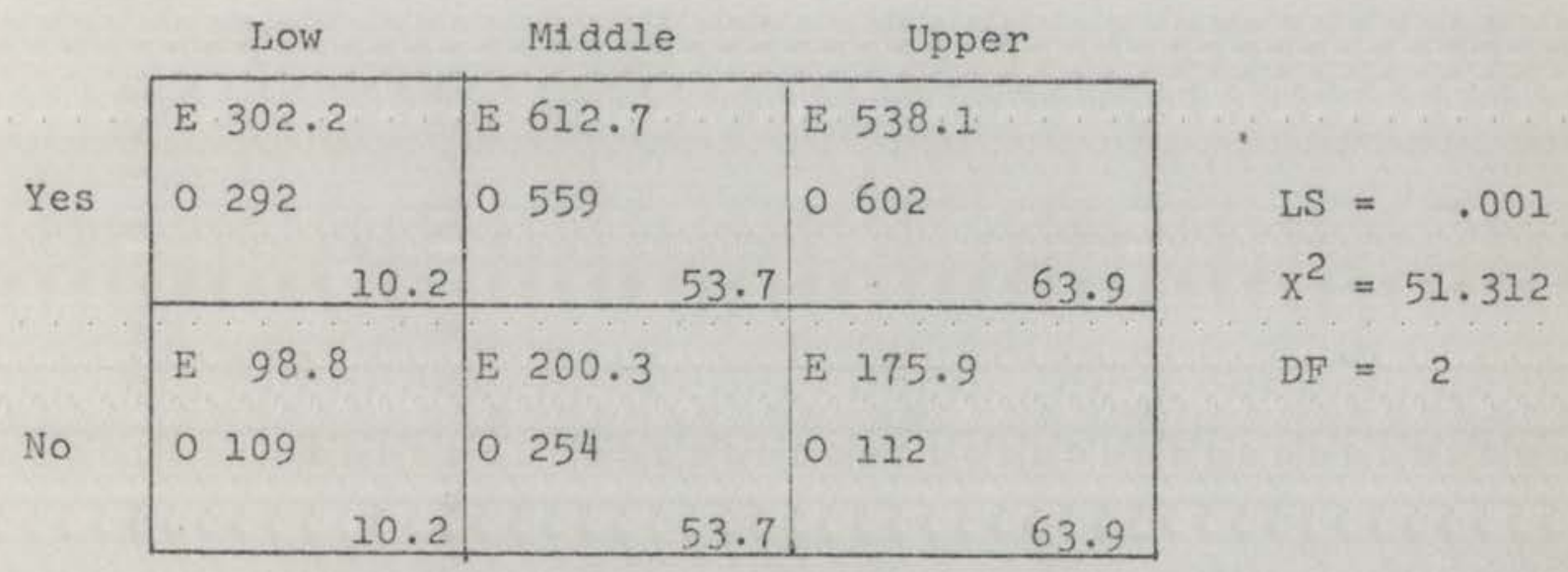


Item K

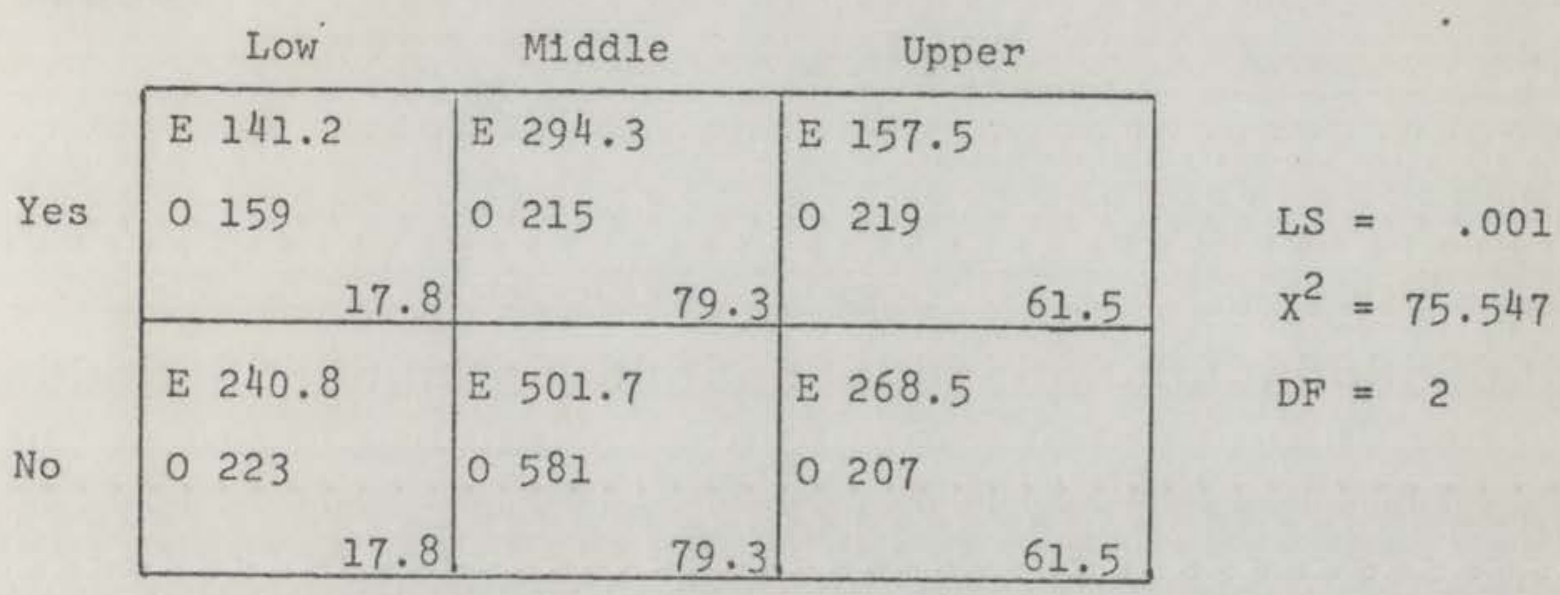

Item L

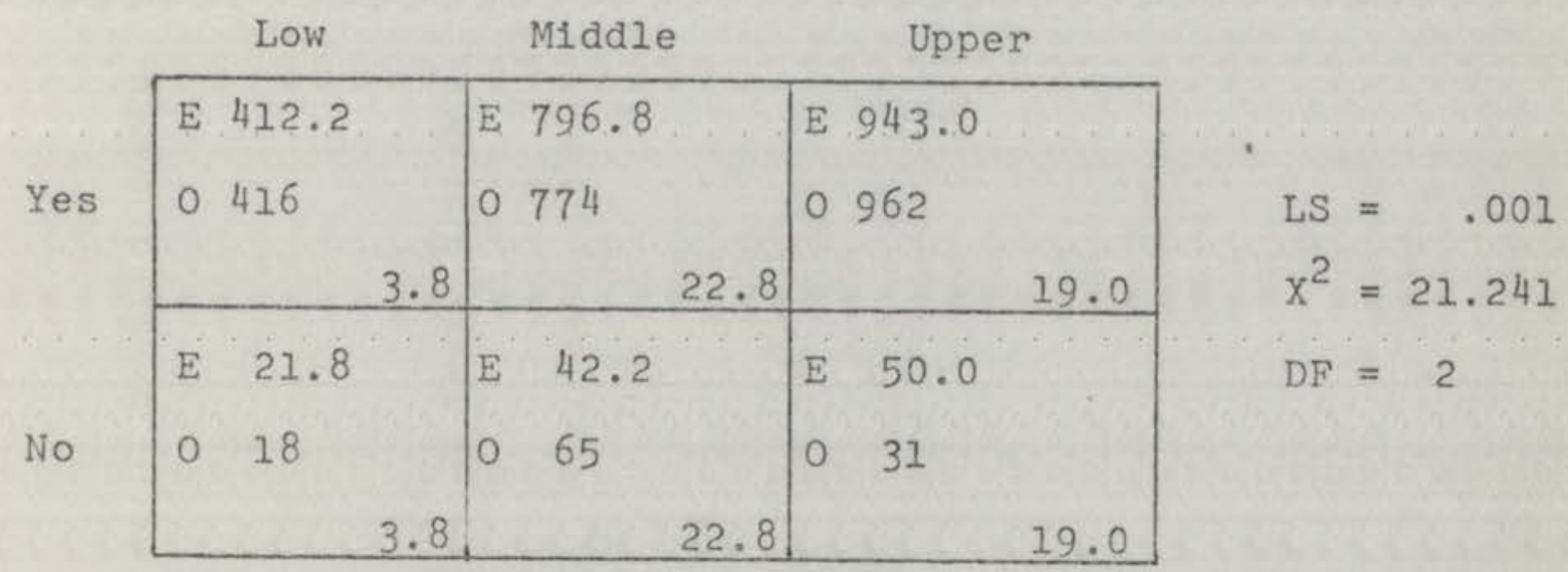


Item $M I$

\begin{tabular}{|c|c|c|c|c|c|c|c|}
\hline & & Low & & Middle & & Upper & \\
\hline & E & 277.8 & E & 628.3 & E & 865.9 & \\
\hline Yes & 0 & 271 & 0 & 624 & 0 & 877 & $\mathrm{LS}=$ \\
\hline & & 6.8 & & $4 \cdot 3$ & & 11.1 & $x^{2}=18.601$ \\
\hline & $\mathrm{E}$ & 5.2 & E & 11.7 & E & 16.1 & $D F=2$ \\
\hline in & 0 & 12 & 0 & 16 & 0 & 5 & \\
\hline & & 6.8 & & 4.3 & & 11.1 & \\
\hline
\end{tabular}

Item M2

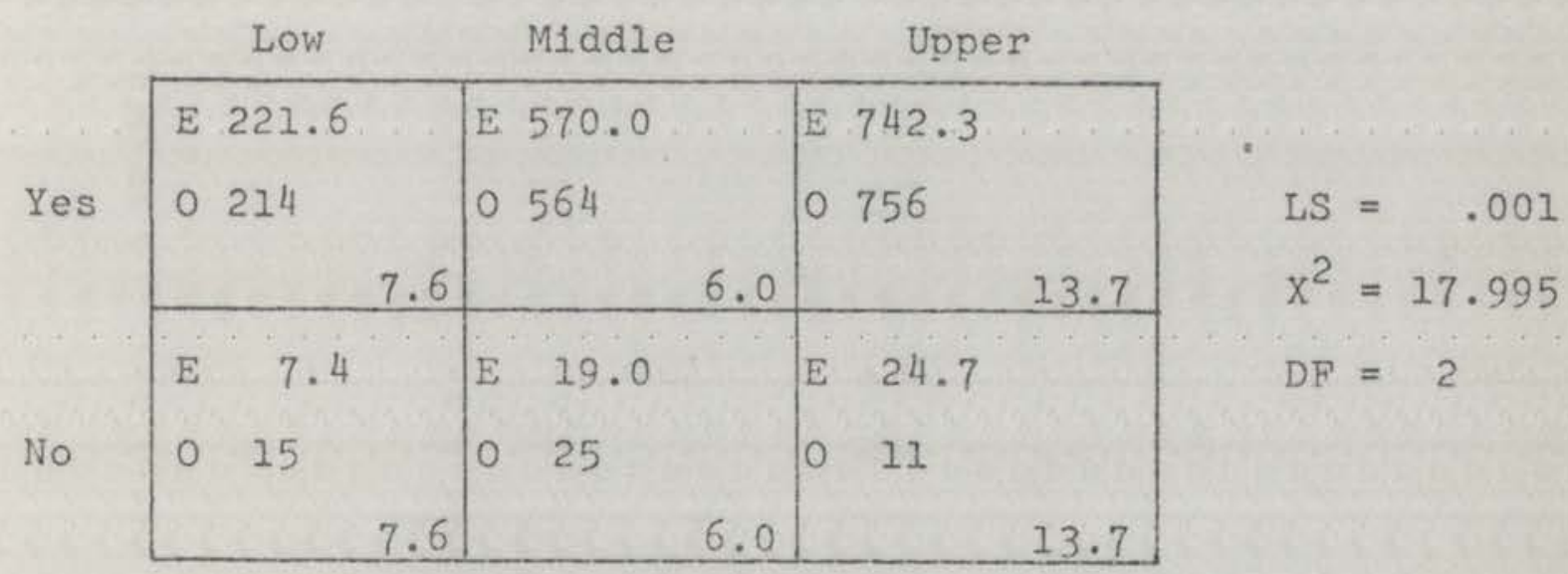


Item M3

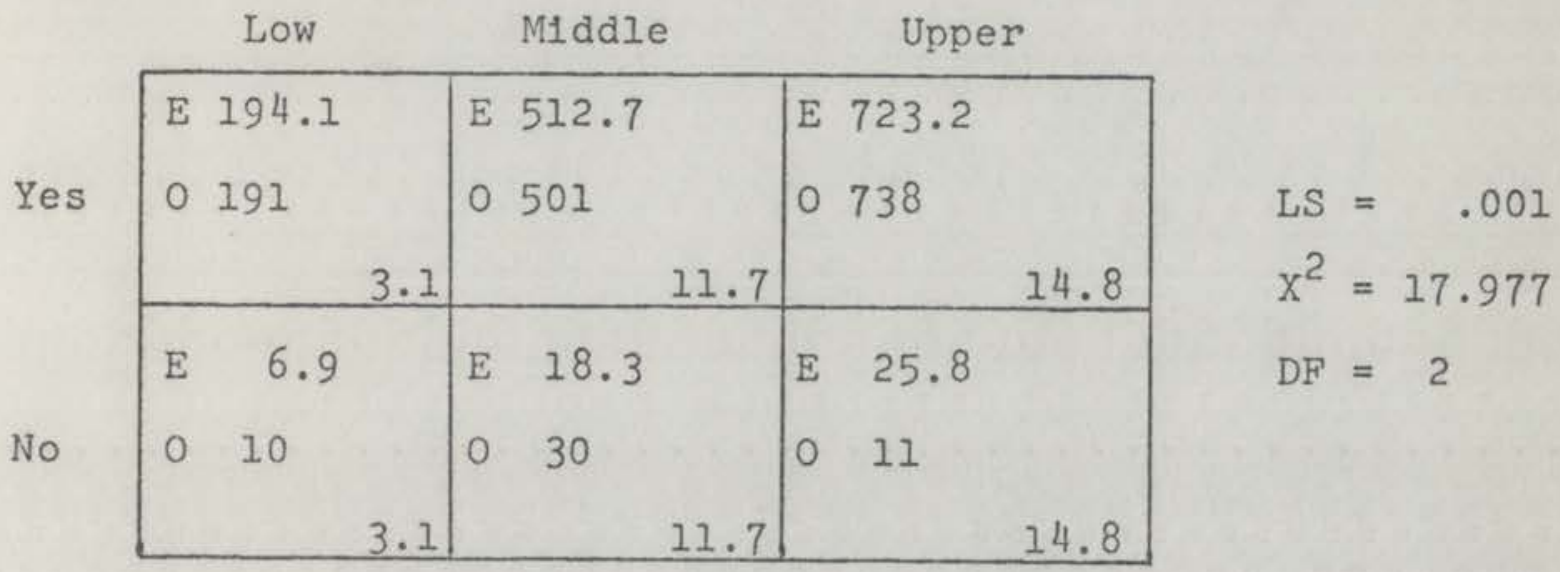

Item N3

\begin{tabular}{|c|c|c|c|c|c|c|c|}
\hline & & Low & & Middle & & Upper & \\
\hline & E & 386.4 & E & 796.4 & $E$ & 986.2 & \\
\hline Yes & 0 & 377 & 0 & 794 & 0 & 998 & $\mathrm{LS}=.001$ \\
\hline & & 9.4 & & 2.4 & & 11.8 & $x^{2}=17.544$ \\
\hline & E & 8.6 & E & 17.6 & E & 21.8 & $D F=2$ \\
\hline & 0 & 18 & 0 & 20 & 0 & 10 & \\
\hline & & 9.4 & & 2.4 & & 11.8 & \\
\hline
\end{tabular}


Item 0

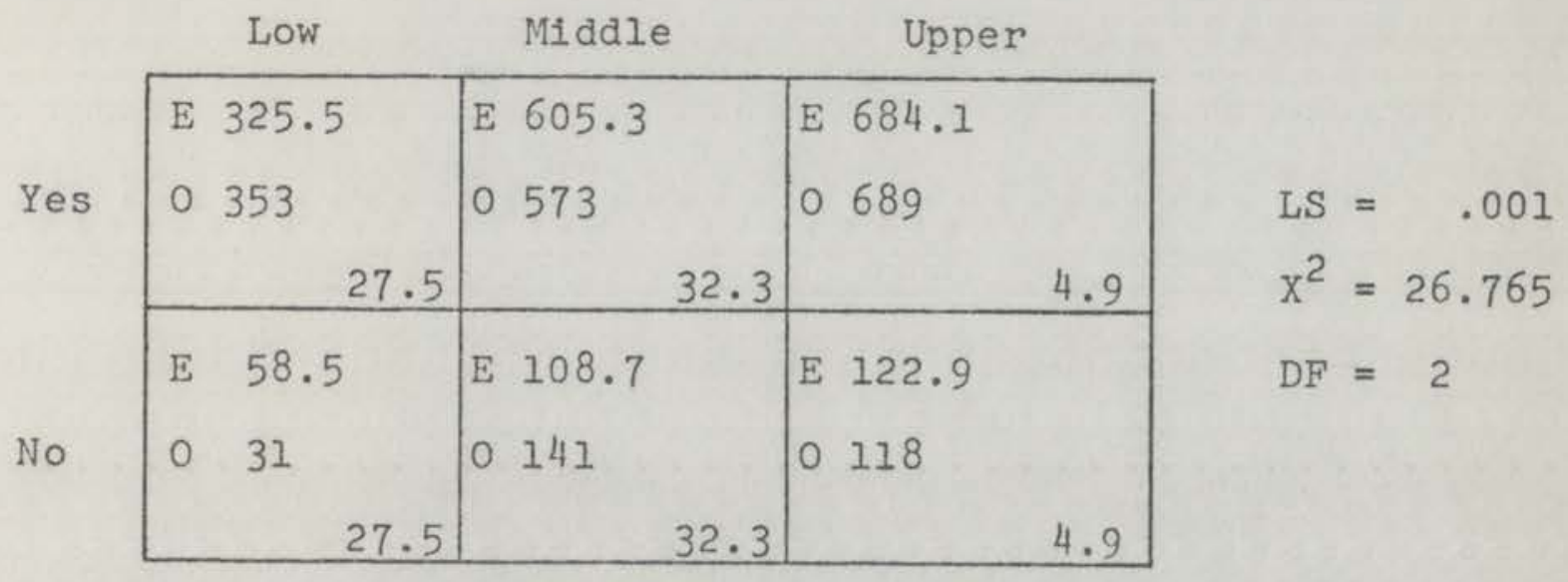

Item P

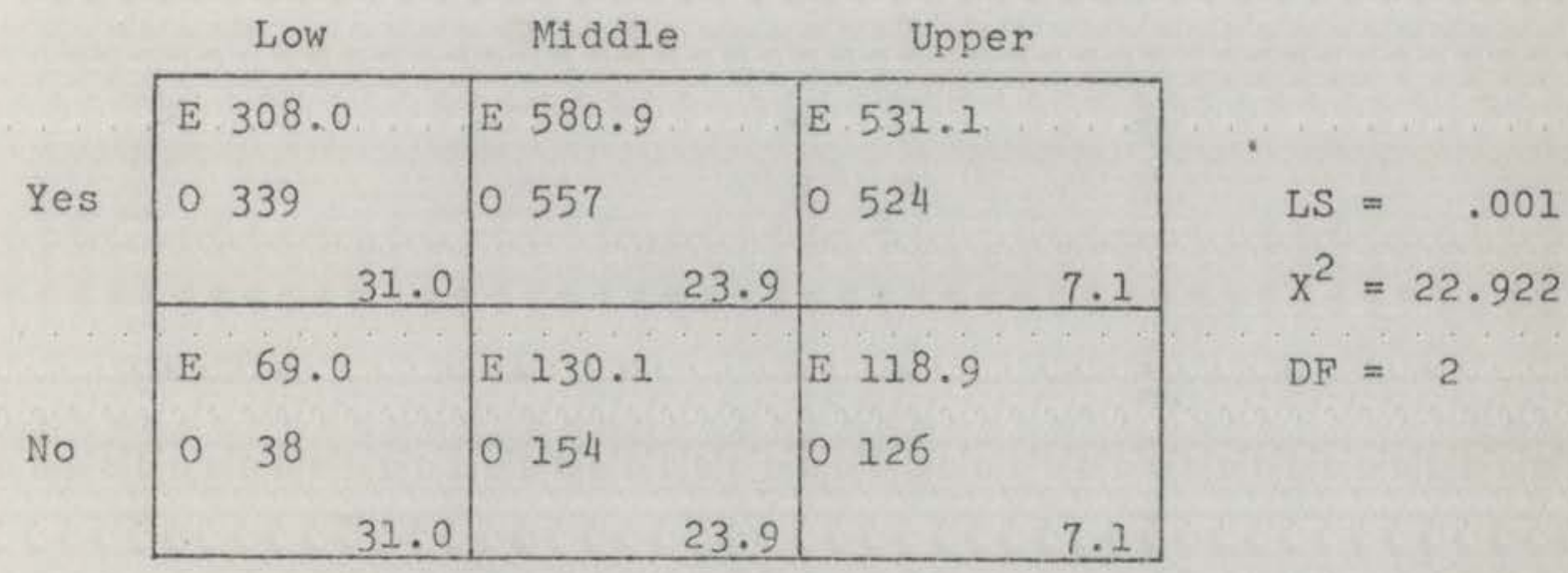


Item Q

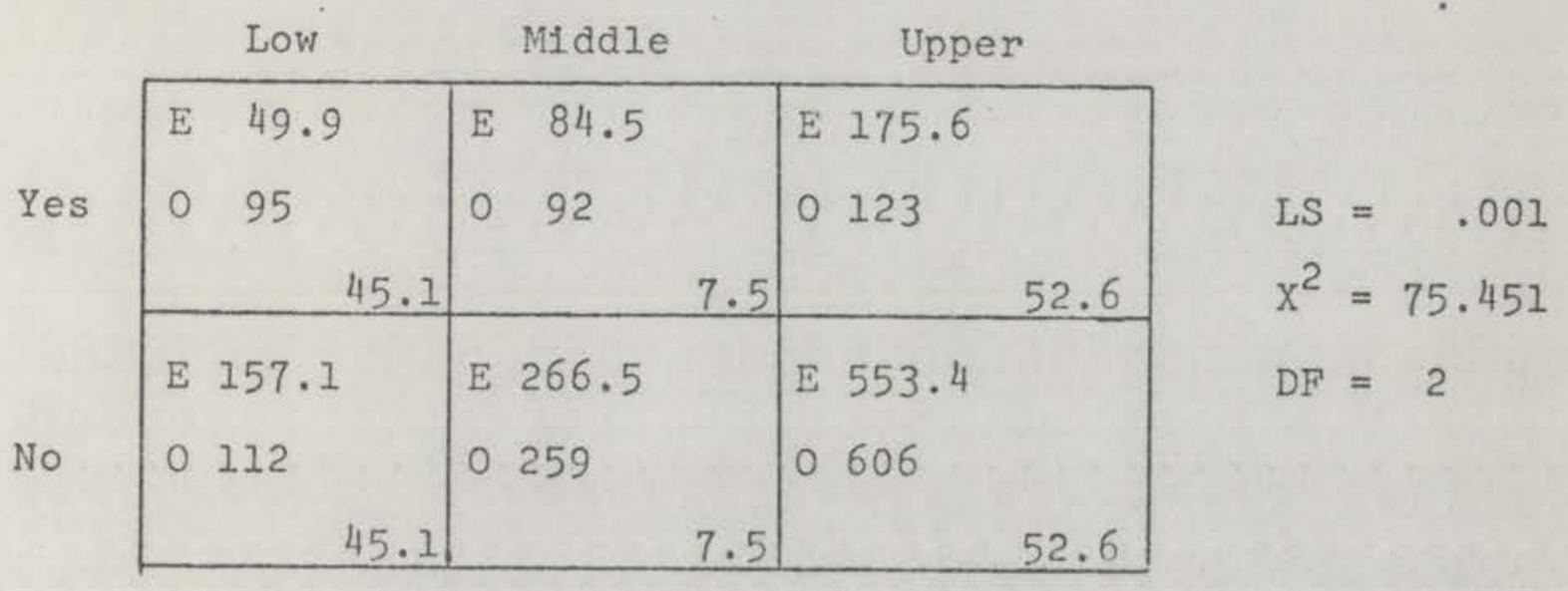

Item RI

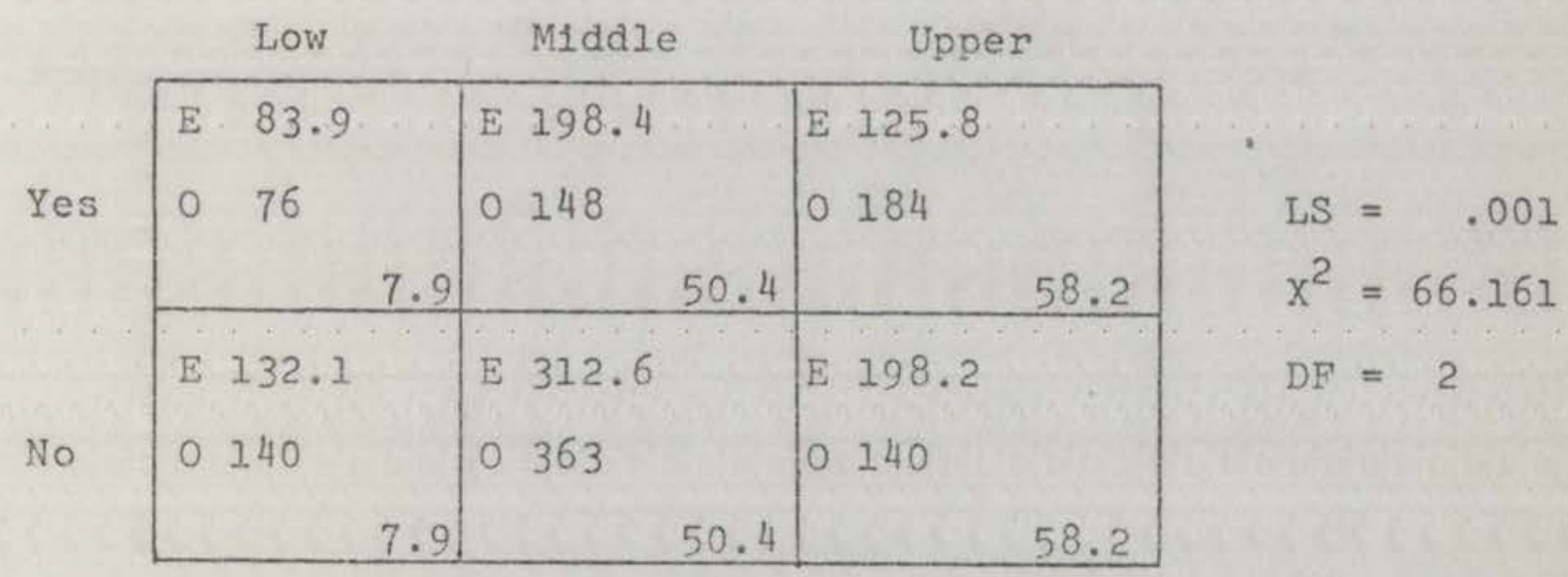




\section{CURRICULUM VITAE}

Birthdate :

Birthplace :

Degrees :

Professional. Experience:
John Joseph Pelizza

The University of New Mexico

Albuquerque, New Mexico

March 20, 1945

New York City, New York

A.A.S., 1964

New York City Community College

Brooklyn, New York

B.S.ed., 1967

Kansas State College of Pittsburg Pittsburs, Kansas

M.S.ed., 1968

Temple University

Philadelphia, Pennsylvania

Graduate Assistant, 1967-68

Temple University

Philadelphia, Pennsylvania

Health Education Teacher, 1968-69 Whitehall High School

Whitehall, Ohio

Graduate Assistant, 1969-71

University of New Mexico

A.1buquerque, New Mexico 